\title{
Estudo microbiológico fecal de linhagens de camundongos, de estirpes de $E$. coli e do meio ambiente em biotérios
}

\author{
Dissertação apresentada ao Programa de \\ Pós-Graduação em Epidemiologia \\ Experimental e Aplicada às Zoonoses da \\ Faculdade de Medicina Veterinária e \\ Zootecnia da Universidade de São Paulo \\ para obtenção do título de Mestre em \\ Medicina Veterinária.
}

Departamento:

Medicina Veterinária Preventiva e Saúde Animal

Área de Concentração:

Epidemiologia Experimental e Aplicada às Zoonoses

Orientador:

Prof. Dr. Nilson Roberti Benites 
Autorizo a reprodução parcial ou total desta obra, para fins acadêmicos, desde que citada a fonte.

DADOS INTERNACIONAIS DE CATALOGAÇÃO-NA-PUBLICAÇÃO

(Biblioteca Virginie Buff D’Ápice da Faculdade de Medicina Veterinária e Zootecnia da Universidade de São Paulo)

T.1935

Minagawa, Clarice Yukari

FMVZ

Estudo microbiológico fecal de linhagens de camundongos, de estirpes de $E$. coli e do meio ambiente em biotérios / Clarice Yukari Minagawa. - São Paulo:

C. Y. Minagawa, 2007.

$108 \mathrm{f}$ : : il

Dissertação (mestrado) - Universidade de São Paulo. Faculdade de Medicina Veterinária e Zootecnia. Departamento de Medicina Veterinária Preventiva e Saúde Animal, 2008.

Programa de Pós-Graduação: Epidemiologia Experimental e Aplicada às Zoonoses.

Área de concentração: Epidemiologia Experimental e Aplicada às Zoonoses.

Orientador: Prof. Dr. Nilson Roberti Benites.

1. Biotério. 2. Camundongos. 3. Linhagens animais. 4. Escherichia coli. 5. Testes de sensibilidade microbiana. I. Título. 
Bom mesmo é ir a luta com determinação, Abraçar a vida com paixão, Perder com classe e vencer com ousadia, pois o triunfo pertence a quem se atreve... A vida é muita para ser insignificante. (Charles Chaplin) 


\section{UNIVERSIDADE DE SÃO PAULO \\ Faculdade de Medicina Veterinaria e Zootecnia Assistência Acadêmica}

Comissão de Bioética

\section{CERTIFICADO}

Certificamos que o Projeto intitulado "Estudo microbiológico de fezes de diferentes linhagens de camundongos do biotério e das luvas dos funcionários que manipulam os animais e pesquisa dos fatores de virulência das estirpes de E. coli isoladas nestes sítios", protocolo $n^{\circ} 725 / 2005$, utilizando 160 camundongos, sob a responsabilidade do Prof. Dr. Nilson Roberti Benites, está de acordo com os princípios éticos de experimentação animal da Comissão de Bioética da Faculdade de Medicina Veterinária e Zootecnia da Universidade de São Paulo e foi aprovado "ad referendun".

(We certify that the Research "Microbiologic study of faeces from different lineages of mice from vivarium and gloves of the worker who manipulate the animals and evaluation of the virulent factors from E.coli isolated from these sites", protocol number 725/2005, utilizing 160 mice, under the responsibility of Prof. Dr. Nilson Roberti Benites, agree with Ethical Principles in Animal Research adopted by Bioethic Commission of the Faculty of Veterinary Medicine and Zootechny of University of São Paulo and was approved "ad referendun", meeting).

São Paulo, 19 de agosto de 2005

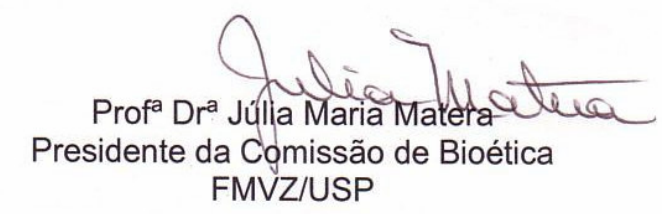

Av. Prof. Dr. Orlando Marques de Paiva, 87 - 05508-270 - Cidade Universitária. "Armando de Salles Oliveira" Fax: (011) 3032-2224 Fone: (011) 3091-7671 -3091-7676 e-mail: fmvz@edu.usp.br 


\section{FOLHA DE AVALIAÇÃO}

Nome do autor: MINAGAWA, Clarice Yukari.

Título: Estudo microbiológico fecal de linhagens de camundongos, de estirpes de E. coli e do meio ambiente em biotérios

Dissertação apresentada ao Programa de Pós-Graduação em Epidemiologia Experimental e Aplicada às Zoonoses da Faculdade de Medicina Veterinária e Zootecnia da Universidade de São Paulo para obtenção do título de Mestre em Medicina Veterinária.

Data: _ I_ 1

\section{Banca Examinadora}

Prof. Dr

Assinatura:

Prof. Dr

Assinatura

Prof. Dr

Assinatura:
Instituição:

Julgamento:

Instituição:

Julgamento:

Instituição:

Julgamento: 
Apoio financeiro FAPESP

Processo n $^{0}$ 05/56146-7 


\section{AGRADECIMENTOS}

Ao Professor Doutor Nilson Roberti Benites pela orientação desde meu estágio durante a graduação, passando pelo estágio curricular, prática profissionalizante e mestrado.

À funcionária Regina e técnica Priscila Anne Melville obrigada pela ajuda e ensinamentos durante todo o tempo que passei no Laboratório de Doenças Infecciosas.

Aos meus amigos do laboratório Ivan, Pulga, Roberto, Ishikawa, Xambinho, Anna Catharina, Mituka, Cideli, Jennifer, Josana, Mônica, Leslie, Tatiana, Adriana, Priscila e Vanessa, obrigada pela companhia, conselhos e todo o conhecimento que me proporcionaram ao longo desta trajetória.

À minha querida amiga Sonia Tatsumi, muito obrigada pela ajuda e apoio nos momentos mais difíceis, além das muitas risadas, desde o primeiro ano da faculdade até hoje!

À minha amiga Gisele obrigada pelas risadas e longas horas de ajuda e companhia na extração, amplificação, eletroforese...

Minhas queridas amigas Alessandra, Flávia, Amani, Carol e Pati Maionese obrigada por me acompanharem nesta fase tão importante para todas nós!

Sheila, Adriana, Ênio, Richard, Mikaela, Professor Paulo e Professor Rodrigo obrigada pela “consultoria” em PCR e pelas palavras de incentivo, quando tudo parecia muitíssimo difícil de ser resolvido!

Aos meus amigos do Biotério do VPT Cláudia, Rosires, Idalina, Nelsinho, Ademir, Seu Luizinho e Herculano por todo ensino e ajuda desde meu primeiro estágio da graduação.

Ao Professor Doutor Silvio Arruda Vasconcellos obrigada por todo apoio, incentivo e ajuda durante todo o mestrado. 
À Professora doutora Andrea Micke Moreno e todos do Laboratório de Sanidade Suína, muito obrigada pela ajuda que me deram para que este trabalho fosse concluído.

À Professora Doutora Nívea Lopes de Souza pela amizade, paciência, conselhos e muitos ensinamentos. Agradeço por me acompanhar, desde o meu primeiro estágio, passando por aquela disciplina que só tinha uma aluna (eu!), pela minha banca de estágio curricular e durante todo o mestrado!

Ao Professor Doutor Rovilson Gilioli e todos de Laboratório de Controle de Qualidade Animal (CEMIB / UNICAMP), tenho certeza que sem aqueles poucos dias de estágio este trabalho não se realizaria! Muito obrigada por todos os ensinamentos e incentivo!

Ao Auxílio à Pesquisa da FAPESP e bolsa CAPES.

Às funcionárias da Biblioteca Virginie Buff D’Ápice pela ajuda desde a graduação, durante todo o mestrado, até a finalização deste trabalho.

A todos os funcionários e professores do Departamento de Medicina Veterinária Preventiva e Saúde Animal que sempre se mostraram dispostos a ajudar no que fosse preciso.

Ao meu amor Dudu, obrigada por todo o carinho, paciência e compreensão que teve durante essa fase. Obrigada também pela ajuda na análise estatística!

À minha família, Pai, Mãe, Kazunari, Del, Beatriz, Tamami e Marcelo. Amo muito todos vocês! Obrigada por me ajudarem a sempre conseguir o meu melhor! 


\section{RESUMO}

MINAGAWA, C. Y. Estudo microbiológico fecal de linhagens de camundongos, de estirpes de $E$. coli e do meio ambiente em biotérios. [Fecal microbiologic study of mice lineages, E. coli strains and the environment in laboratory animal facilities]. 2008. $108 \mathrm{f}$. Dissertação (Mestrado em Medicina Veterinária) - Faculdade de Medicina Veterinária e Zootecnia, Universidade de São Paulo, São Paulo, 2007.

Os camundongos têm sido amplamente utilizados na experimentação desde o século XVII, devendo sua qualidade microbiológica ser pesquisada e mantida, para evitar que eles adoeçam ou morram durante o experimento, não transmitam zoonoses e para que os resultados apresentados no experimento sejam confiáveis. A Escherichia coli faz parte da microbiota entérica dos mamíferos, podendo algumas linhagens causar infecções. As estirpes patogênicas apresentam diferentes fatores de virulência, como as endotoxinas, adesinas, enterotoxinas, fator citotóxico necrosante e as hemolisinas. Este trabalho teve como objetivos: analisar as microbiotas aeróbias bacteriana e fúngica presentes no intestino das linhagens de camundongos Swiss, C57BL/6, BALB/c, C3H/HePas, C3H/HeJ, MDX e YCx43, verificando se existem diferenças entre elas; avaliar a suscetibilidade "in vitro" frente aos antimicrobianos das E. coli isoladas, verificando se existem diferenças entre as linhagens; verificar a ocorrência de resistência a múltiplos antimicrobianos nas $E$. coli isoladas; pesquisar os fatores de virulência das $E$. coli isoladas, também investigando se existem diferenças destes entre as linhagens estudadas; identificar os microrganismos presentes nos diferentes ambientes em que estes animais são mantidos, verificando se existem diferenças entre eles. Os camundongos foram necropsiados e coletou-se uma pequena quantidade de seu conteúdo fecal que foi semeado nos meios de cultura BHI, ágar sangue de carneiro 5\%, ágar MacConkey e ágar Saboraud dextrose. Foi realizando o antibiograma e PCR das E. coli isoladas. Realizou-se a cultura de suabes da mesa, maçaneta de porta e exterior das luvas dos funcionários. Verificouse que as linhagens de camundongos estudadas apresentam microbiotas fecais diferentes; as estirpes de E. coli são diferentes em cada linhagem e apresentam resistência a múltiplos antibióticos, que as estirpes de E. coli isoladas não são patogênicas, que as bactérias isoladas nas salas do biotério não foram influenciadas pela microbiota fecal dos camundongos e que o monitoramento microbiológico de rotina dos animais, do ambiente e dos técnicos, e as normas de biossegurança são indispensáveis e devem ser sempre adotados e mantidos no biotério.

Palavras-chave: Biotério. Camundongos. Linhagens animais. Escherichia coli. Teste de sensibilidade microbiana. 


\begin{abstract}
MINAGAWA, C. Y. Fecal microbiologic study of mice lineages, $E$. coli strains and the environment in laboratory animal facilities. [Estudo microbiológico fecal de linhagens de camundongos, de estirpes de E. coli e do meio ambiente em biotérios.] 2008. 108 f. Dissertação (Mestrado em Medicina Veterinária) - Faculdade de Medicina Veterinária e Zootecnia, Universidade de São Paulo, São Paulo, 2007.
\end{abstract}

Mice have been largely used at experiences since $17^{\circ}$ century, so their microbiological quality should be investigated and kept safety in order to avoid they become ill or die during an investigation and don't transmit zoonosis to those who handle them; this is important in order to make the results presented in the experience be reliable. The Escherichia coli is part of enteric microbiota of mammals, and some of them may cause infections. The pathogenic strains of $E$. coli show different virulence factors, such as endotoxins, adhesins, enterotoxins, necrotizing citotoxic factors (cnf) and hemolysins. This study has aimed to analyze: the bacterial and fungi aerobic microbiota present at intestine of lineages Swiss, C57BL/6, $\mathrm{BALB} / \mathrm{c}, \mathrm{C} 3 \mathrm{H} / \mathrm{HePas}, \mathrm{C} 3 \mathrm{H} / \mathrm{HeJ}, \mathrm{MDX}$ and $\mathrm{YCx} 43$ mice, checking if there are differences among them; to evaluate the susceptibility in vitro to antimicrobial agents of E. coli isolated, checking if there are differences among lineages; to verify the occurrence of resistance to multiple antimicrobial agents at E. coli isolated; to investigate the virulence factor's of lineages of E. coli, also checking if there are differences among these lineages and the lineages studied; identify the micro-organisms presented at different environments where these animals are kept, checking if there are differences among them. The mice were submitted to necropsy and it was collected a little amount of their fecal content. This fecal content was seeded in culture mediums of BHI, sheep blood agar 5\%, MacConkey agar and Saboraud dextrose agar. The mice's lineages studied have different fecal microbiotas; the $E$. coli strains are different in each lineage and they've showed resistance to multiple antibiotics; the E. coli strains are not pathogenics; isolated bacteria on animal rooms were not affected by mice's fecal microbiotas, the microbiological monitoring of animals and biosafety standards always must be adopted and followed at animal rooms.

Word-keys: Laboratory animal facilities. Mice. Animal strains. Escherichia coli. Microbian sensibility test. 


\section{LISTA DE QUADROS}

Quadro 1 - Listagem de "primers" que foram utilizados na PCR para amplificar fragmentos de diferentes genes para enterotoxinas, verotoxinas e de diferentes genes para pap, $h l y, i u c, c n f 1$, sfa e afa. 


\section{LISTA DE FIGURAS}

Figura 1 - Esquema do processamento das fezes coletadas de camundongos........................56

Figura 2 - Esquema da coleta das amostras de suabes realizados na mesa do biotério

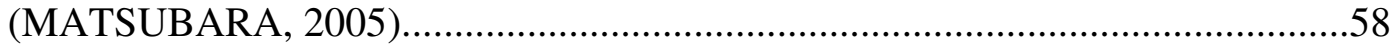

Figura 3 - Ilustração das comparações entre as freqüências relativas de bactérias encontradas nas linhagens de camundongos estudadas........................................................67 


\section{LISTA DE GRÁFICOS}

Gráfico 1 - Porcentagem das bactérias isoladas nas linhagens de camundongos estudadas. 62

Gráfico 2 - Porcentagem das E. coli resistentes aos antimicrobianos testados nas linhagens de camundongos.

Gráfico 3 - Porcentagem das E. coli intermediárias aos antimicrobianos testados nas

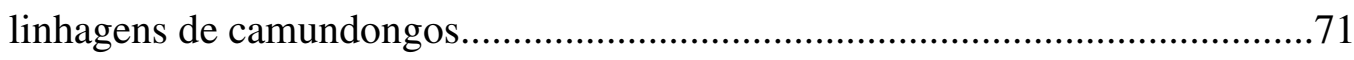

Gráfico 4 - Porcentagem das E. coli sensíveis aos antimicrobianos testados nas linhagens de camundongos .73

Gráfico 5 - Porcentagem das bactérias isoladas no ar das nas três salas de

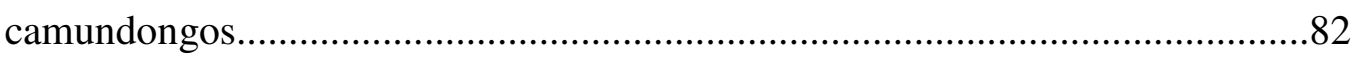

Gráfico 6 - Porcentagem das bactérias isoladas nas luvas das três salas de camundongos e luvas não utilizadas. .82

Gráfico 7 - Porcentagem das bactérias isoladas nas mesas das três salas de camundongos

Gráfico 8 - Porcentagem das bactérias isoladas nas maçanetas das portas das três salas de camundongos .83 


\section{LISTA DE TABELAS}

Tabela 1 - Frequiência (n) e porcentagem (p) das bactérias isoladas nas linhagens de camundongos estudadas - São Paulo, agosto.2005 - dezembro. 2006.

Tabela 2 - P-valores encontrados no teste para avaliação da freqüência relativa de bactérias presentes no ceco das linhagens de camundongos estudadas.

Tabela 3 - Comparação das linhagens de camundongos duas a duas para cada bactéria.....

Tabela 4 - Comparação das linhagens de camundongos duas a duas para cada bactéria (continuação)

Tabela 5 - Frequiência (n) e porcentagem (p) das E. coli resistentes aos antimicrobianos testados, nas linhagens de camundongos - São Paulo, agosto.2005 - dezembro. 2006. 68

Tabela 6 - Freqüência (n) e porcentagem (p) das E. coli intermediárias aos antimicrobianos testados nas linhagens de camundongos - São Paulo, agosto.2005 - dezembro. 2006.

Tabela 7 - Frequiência (n) e porcentagem (p) das E. coli sensíveis aos antimicrobianos testados nas linhagens de camundongos - São Paulo, agosto.2005 - dezembro. 2006. .72

Tabela 8 - P-valores encontrados no teste exato de Fisher realizado com os resultados dos antibiogramas. 
Tabela 9-P-valores encontrados no teste de ANOVA para testar quais linhagens de camundongos apresentaram mais de $50 \%$ de resistência aos antimicrobianos.

Tabela 10 - P-valores encontrados no teste de ANOVA para testar quais linhagens apresentaram mais de $50 \%$ de sensibilidade aos antimicrobianos. 76

Tabela 11 - Freqüência de resistência múltipla de E. coli aos antimicrobianos nas linhagens de camundongos estudadas.

Tabela 12 - Resultados dos índices de resistência múltipla (IRM) calculados para as linhagens de camundongos estudadas. 78

Tabela 13 - P-valores das comparações dos índices de resistência múltipla (IRM) entre as linhagens de camundongos estudadas

Tabela 14 - Frequiência(n) e porcentagem (p) das bactérias isoladas das três salas de camundongos - São Paulo, agosto.2006 - fevereiro. 2007.

Tabela 15 - Estatística descritiva da contagem de unidades formadoras de colônia (ufc) realizada nas três salas de camundongos - São Paulo, agosto.2006 fevereiro. 2007

Tabela 16 - P-valores encontrados no teste de MANOVA para as bactérias isoladas nas luvas das três salas de camundongos 85

Tabela 17 - P-valores encontrados no teste de MANOVA para a proporção de Staphylococcus spp encontrados nas luvas das três salas de camundongos .86

Tabela 18 - P-valores encontrados no teste de MANOVA para estudo da proporção de bactérias presentes no ar, mesa e porta das três salas de camundongos. .86 


\section{LISTA DE ABREVIATURAS E SIGLAS}

$\mathrm{A} / \mathrm{E}=$ lesão de fixação e esfacelamento

$\mathrm{BHI}=$ Brain Heart Infusion

DAEC = Escherichia coli de aderência difusa

$\mathrm{EAggEC}=$ Escherichia coli enteroagregativa

EHEC = Escherichia coli enterohemorrágica

EIEC $=$ Escherichia coli enteroinvasora

$\mathrm{EPEC}=$ Escherichia coli enteropatogênica

ETEC $=$ Escherichia coli enterotoxigênica

HUS = síndrome hemolítica urêmica

LEE $=$ locus de esfacelamento do enterócito

LPS = lipopolissacarídeo

LT = toxina termolábil

PCR $=$ reação em cadeia da polimerase

$\mathrm{ST}=$ toxina termoestável

STx $=$ shiga toxina

UFC = unidade formadora de colônia

UPEC = Escherichia coli uropatogênica 
1 INTRODUÇÃO

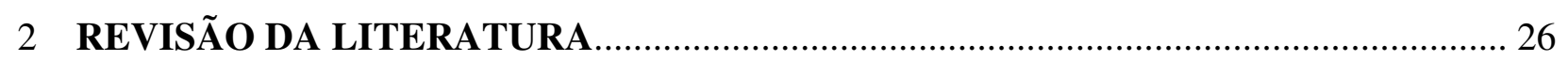

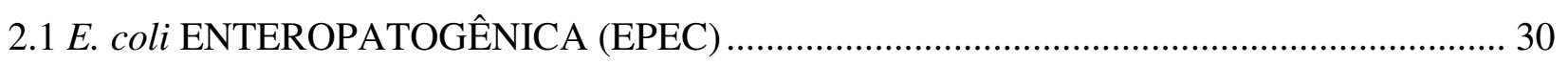

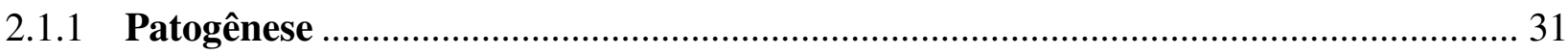

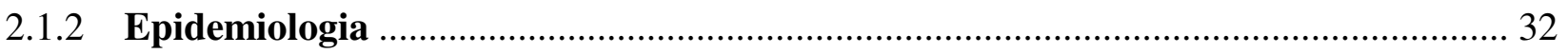

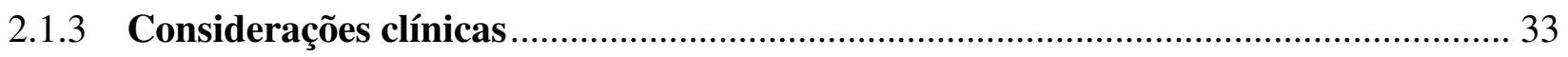

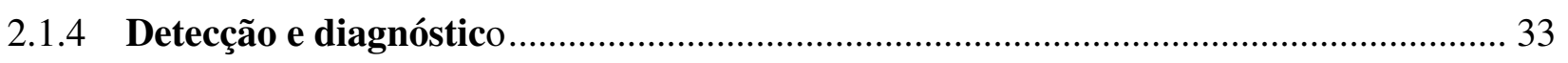

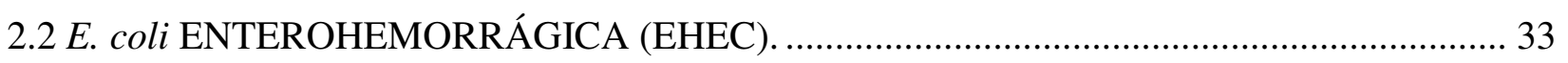

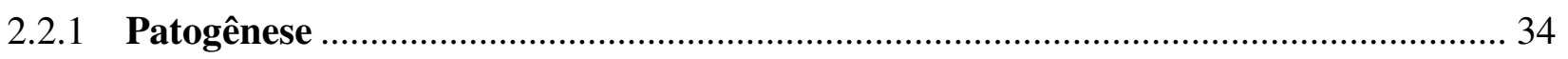

2.2.2 Shiga-toxina (Stx) ......................................................................................... 35

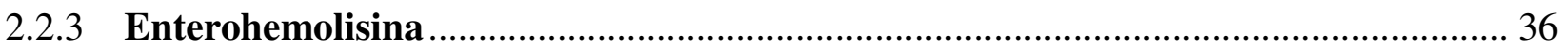

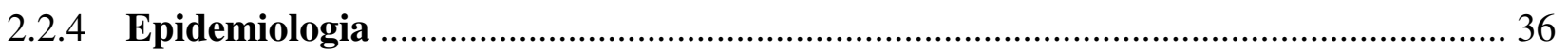

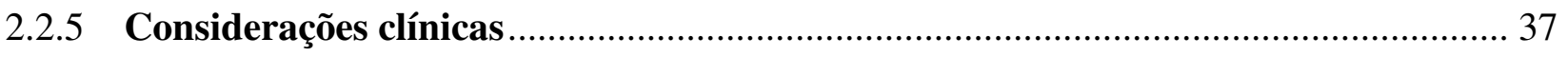

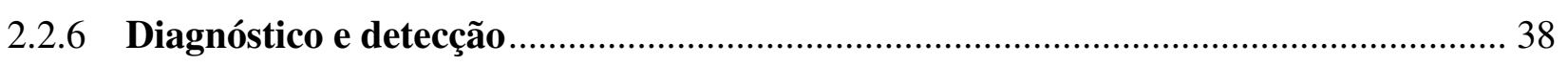

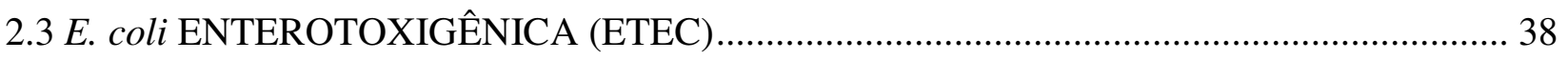

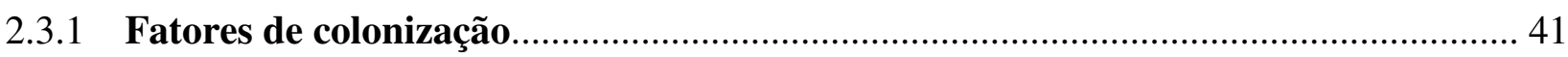

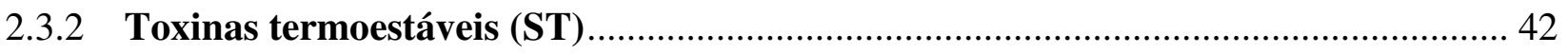

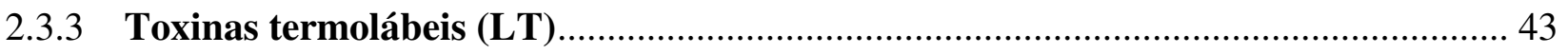

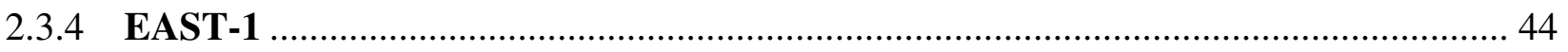

2.4 E. coli ENTEROINVASORA (EIEC) ………………………………………………. 45

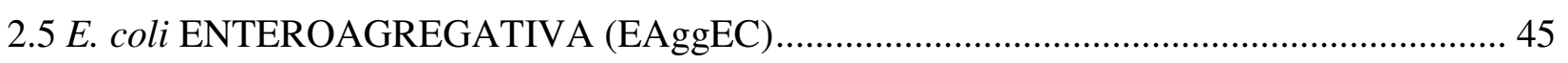

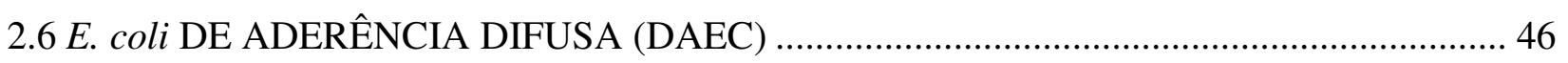

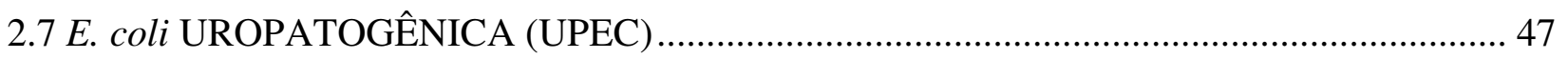

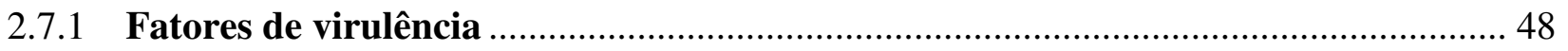

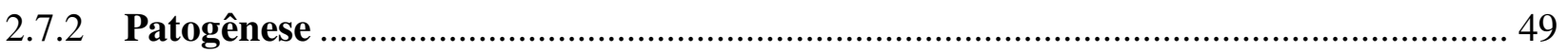

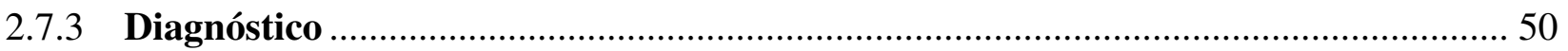

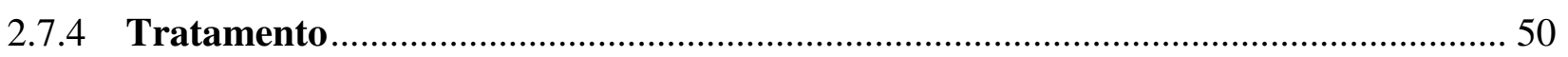

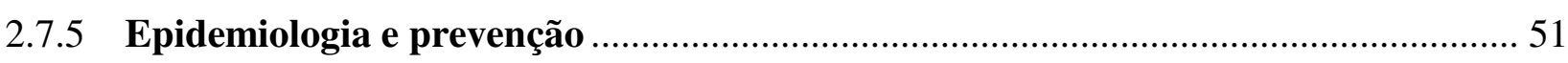

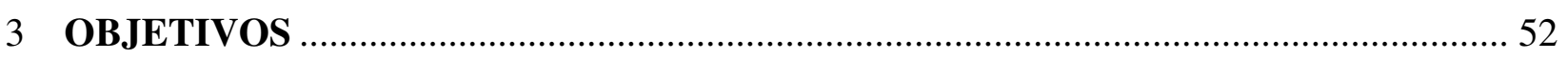

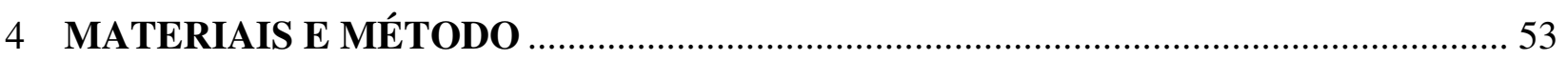


4.1 COLHEITA DO MATERIAL

4.2 ISOLAMENTO E IDENTIFICAÇÃO DOS MICRORGANISMOS PRESENTES NAS FEZES DOS ANIMAIS 54

4.3 TESTES DE SUSCETIBILIDADE “IN VITRO” DAS ESTIRPES DE E. coli ISOLADAS DAS FEZES DOS ANIMAIS FRENTE A DIFERENTES ANTIMICROBIANOS E PESQUISA DE RESISTÊNCIA MÚLTIPLA E SEU ÍNDICE 54

4.4 ESTUDO DA PRESENÇA DE FATORES DE VIRULÊNCIA EM ESTIRPES DE E. coli ISOLADAS DAS FEZES DOS ANIMAIS UTILIZANDO A REAÇÃO EM CADEIA DA POLIMERASE . 55

4.5 ISOLAMENTO E IDENTIFICAÇÃO DOS MICRORGANISMOS PRESENTES NO AMBIENTE E LUVAS DOS MANIPULADORES. 57

4.6 ANÁLISE ESTATÍSTICA. 59

5 RESULTADOS 60

5.1 ISOLAMENTO E IDENTIFICAÇÃO DOS MICRORGANISMOS PRESENTES NAS FEZES DOS ANIMAIS 60

5.2 TESTES DE SUSCETIBILIDADE “IN VITRO” DAS ESTIRPES DE E. coli ISOLADAS DAS FEZES DOS ANIMAIS FRENTE A DIFERENTES ANTIMICROBIANOS 68

5.3 ESTUDO DA PRESENÇA DE FATORES DE VIRULÊNCIA EM ESTIRPES DE E. coli ISOLADAS DAS FEZES DOS ANIMAIS UTILIZANDO A REAÇÃO EM CADEIA DA POLIMERASE . 80

5.4 ISOLAMENTO E IDENTIFICAÇÃO DOS MICRORGANISMOS PRESENTES NO AMBIENTE E LUVAS DOS MANIPULADORES. 80

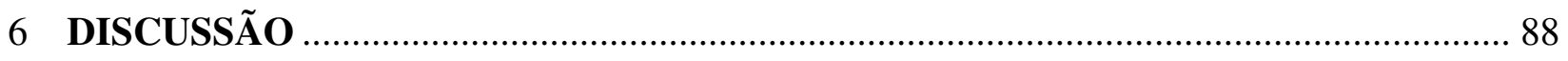

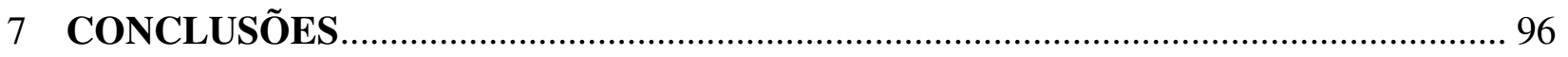

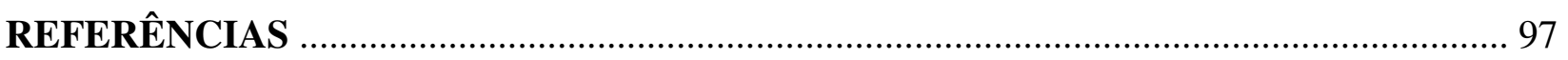




\section{INTRODUÇÃO}

Desde o século XVII os camundongos são utilizados em experimentação, havendo um grande desenvolvimento no estudo de sua genética a partir do século XX, o que favoreceu criação de diferentes linhagens, entre elas as isogênicas, heterogênicas, transgênicas e "knockout". Tal fato desencadeou um grande aumento no número de pesquisas utilizando esta espécie, que na verdade vem aumentando até hoje. Sendo assim, o emprego do camundongo tornou-se usual, passando a dominar completamente as práticas experimentais (ANDERSEN et al., 2004).

Uma linhagem isogênica é produzida pelo cruzamento entre irmãos, por 20 ou mais gerações. Exceto pela diferença sexual, os camundongos de uma mesma linhagem isogênica são o mais semelhante, geneticamente possível. A vantagem na sua utilização se traduz no fato de que a padronização de linhagens isogênicas reduz possíveis variações em resultados experimentais devido ao seu padrão genético (ANDERSEN et al., 2004).

Camundongos heterogênicos são obtidos através de acasalamentos não consangüíneos, que mantêm a variação genética relativamente constante, possibilitando a reprodução de populações naturais (ANDERSEN et al., 2004; DOS SANTOS, 2006).

O maior conhecimento desses animais permitiu ainda o desenvolvimento de camundongos "knockouts", dos quais se retira o gene de interesse ou quando ele perde sua função, tornando-o um modelo para estudar doenças, pois ao retirar um fragmento de DNA, passa a ter uma informação genética nova. Essa técnica gerou um rápido desenvolvimento de modelos animais, designados para estudos de regulação e expressão gênica, assim como de patogênese e tratamento de doenças de animais e humanos.(BRAUMANS, 1999; ANDERSEN et al., 2004).

Os camundongos da linhagem BALB/c estão entre os mais utilizados dentre os isogênicos, particularmente conhecidos pela produção de anticorpos monoclonais. Originaram-se de um estoque de camundongos albinos adquiridos por H. Bagg, em 1913, são considerados animais dóceis, mas muito ansiosos, sendo utilizados em estudos envolvendo tratamentos antidepressivos. São utilizados também em muitas outras áreas de pesquisa por apresentarem grande número de animais por ninhada e longa vida reprodutiva (JACKSON LABORATORY, 2007; MACDOWELL; ALLEN; MACDOWELL, 1927; TACONIC, 2007). 
Em 1920, Strong acasalou camundongos da linhagem Little Dilute Brown com uma fêmea albina. Dentre as numerosas progênies ao longo dos meses, uma fêmea desenvolveu diversos nódulos, que foram identificados como adenocarcinomas. Esta fêmea foi cruzada com seu irmão e após 21 gerações de acasalamentos, todas as fêmeas entre sete e dez meses de idade desenvolviam carcinoma da glândula mamária, originando-se assim a linhagem C3H (STRONG, 1935).

A disseminação desta linhagem, primeiramente empregada em estudos de tumores mamários e mais tarde em outras pesquisas, como a da leucemia, resultou na formação de sublinhagens de diferentes laboratórios, como a C3H/He, C3H/St e C3H/Bi (KROG; MOUTIER, 1978).

Ainda há a linhagem $\mathrm{C} 3 \mathrm{H} / \mathrm{HeJ}$, que é usada em uma grande variedade de pesquisas, como câncer, imunologia, inflamação e biologia cardiovascular. Esses animais são homozigotos para uma mutação que leva a degeneração retinal, causando cegueira. Além disso, esta linhagem apresenta alta suscetibilidade à infecção por bactérias Gram negativas (JACKSON LABORATORY, 2007; STAATS, 1985).

Os camundongos da linhagem isogênica C57BL/6 são os mais utilizados do mundo, sendo refratários a uma grande variedade de tumores. Diferentes áreas de pesquisa utilizam este camundongo, como a biologia cardiovascular, genética e imunologia, sendo também muito utilizados na produção de linhagens transgênicas. São muito suscetíveis a obesidade induzida pela dieta, diabetes tipo II e arterosclerose, além de apresentarem alta incidência de microftalmia e outras anormalidades oftálmicas, baixa densidade óssea e perda de pêlos (JACKSON LABORATORY, 2007).

Os camundongos da linhagem MDX foram obtidos através de uma mutação espontânea que ocorreu nos camundongos C57BL/10. Esta mutação gerou animais homozigotos viáveis, que apresentavam um elevado nível sérico de enzimas musculares, além de exibirem lesões histologicamente semelhantes à distrofia muscular humana, servindo como modelo para esta doença (BULFIELD et al., 1984).

A linhagem albina heterogênica Swiss tem sido utilizada há décadas em diferentes áreas de pesquisa, como o teste de segurança de novos medicamentos. As fêmeas desta linhagem também são consideradas ideais receptoras de embriões de outras linhagens de camundongos (TACONIC, 2007). 
Os camundongos deficientes em conexina $43(\mathrm{Cx} 43)$ foram originalmente estabelecidos por Reaume et al. (1995). Essa deficiência foi obtida com a inserção do gene neo, de resistência a neomicina, no exon 2 de $\mathrm{Cx} 43$, diminuindo sua expressão gênica em 50\%. O background genético original destes camundongos era da linhagem C57BL/6, que foi sucessivamente cruzada com camundongos CD-1. Animais homozigotos para esta deficiência apresentam letalidade neonatal devido à má formação cardíaca (OLORIS, 2005).

O padrão microbiológico destes animais deve ser checado e mantido principalmente para evitar doenças e alta mortalidade, os quais acarretariam maiores gastos e retardo nos experimentos. A boa condição de saúde dos animais também leva a uma diminuição de interferências em resultados de pesquisas, e garante a segurança de técnicos e pesquisadores, uma vez que as zoonoses são uma das principais causas de doenças ocupacionais no biotério. Além disso, esses animais estão se tornando cada vez mais populares entre as crianças, que os adquirem para criá-los como "pets", estando elas também expostas a uma possível contaminação transmitida pelos animais (BOPP et al., 1999).

Deve-se, então zelar pela biossegurança, que pode ser traduzida como um conjunto de ações voltadas para a prevenção, minimização ou eliminação dos riscos inerentes à experimentação animal e que podem comprometer a saúde do homem, dos animais, do meio ambiente ou da qualidade dos trabalhos desenvolvidos. Neste contexto está inserida a atuação do médico veterinário, que é essencial para o estabelecimento e manutenção das condições adequadas no biotério (CARDOSO, 2001).

Um dos microrganismos que podem ser encontrados nas fezes dos camundongos é a Escherichia coli, que pertence à Família Enterobacteriaceae. Trata-se um bastonete Gram negativo, anaeróbio facultativo, podendo ou não apresentar flagelo (ORSKOV, 1994; HIRSH; ZEE, 2003).

A microbiota normal do intestino é a maior proteção dos animais e do homem contra a colonização de bactérias patogênicas. A E. coli é uma das primeiras bactérias, junto com o Streptococcus spp a colonizar o intestino de recém-nascidos como o camundongo, rato, galinha e também do homem, produzindo este efeito protetor (NATARO; KAPER, 1998; HUDALT; GUIGNOT; SERVIN, 2001). 
A E. coli faz parte da microbiota de indivíduos sadios, geralmente permanecendo no intestino porém, em hospedeiros imunossuprimidos ou quando as barreiras gastrointestinais são violadas, até mesmo as estirpes não patogênicas podem causar infecções. Estas podem estar limitadas à superfície mucosa ou se disseminarem pelo organismo, o que pode resultar em três síndromes gerais: infecção do trato urinário, sepse/meningite e doença entérica/diarréia (NATARO; KAPER, 1998; BOPP et al., 1999; PALERMO-NETO; ALMEIDA, 2002).

Em 1944, Kauffman propôs um esquema de classificação sorológica para a E. coli, que é usada até hoje, com algumas modificações. De acordo com este modelo, a bactéria é sorotipada com base no antígeno O (somático), H (flagelar) e K (capsular) (NATARO; KAPER, 1998).

A maior parte das estirpes de E. coli apresentam flagelos peritríquios, portanto são móveis, sendo definidos 56 antígenos H sorologicamente distintos. Muitas linhagens de E. coli apresentam fímbrias (pili), que podem estar espalhadas por toda a superfície bacteriana e relacionam-se a funções específicas, como adesão (ORSKOV, 1994; BOPP et al., 1999; HIRSH; ZEE, 2003).

Já os antígenos K são polissacarídeos capsulares importantes para algumas estirpes de $E$. coli como as invasivas, que entram em contato com os metabólitos e células do hospedeiro (HIRSH; ZEE, 2003).

Os antígenos $\mathrm{O}$, antígenos somáticos ou endotoxinas, correspondem à fração polissacarídica do lipopolissacarídeo (LPS), componente comum da parede bacteriana das enterobactérias, que é liberado quando a bactéria é destruída. O LPS pode causar lesão endotelial, levando a coagulação intravascular disseminada e choque endotóxico (HIRSH; ZEE, 2003; QUINN et al., 2005).

As estirpes patogênicas de E. coli podem produzir diferentes fatores de virulência importantes do ponto de vista médico, e dentre eles podem ser citadas as endotoxinas, adesinas, enterotoxinas, toxinas shiga-símile (verotoxina), fator citotóxico necrosante (CNF), as hemolisinas, o fator de resistência aos antimicrobianos e os sideróforos (HIRSH; ZEE, 2003; QUINN et al., 2005).

Quando a bactéria encontra-se em superfícies mucosas, um importante fator de virulência é a adesina fimbrial. Ela está presente em linhagens de $E$. coli enterotoxigênicas, e permite uma ligação sólida da bactéria a mucosas, o que facilita sua colonização. Apresentam importância na 
Medicina Veterinária as adesinas K88 (que acomete suínos), K99 (bezerros e cordeiros), 987P (suínos recém-nascidos) e F41 (bezerros) (HIRSH; ZEE, 2003; QUINN et al., 2005).

As enterotoxinas podem ocorrer na forma termoestável (ST) ou termolábil (LT). A STa promove um acúmulo de líquidos no intestino de camundongos lactentes e STb, acúmulo de líquidos em leitões lactentes e desmamados. Já a ação da toxina termolábil LT1 tem sido observada na E. coli enterotoxigênica (ETEC) de suínos, sendo que a maioria desses isolados produz a LT1 também apresenta a adesina K88. A enterotoxina LT2 foi observada em algumas linhagens de ETEC de bovinos (HIRSH; ZEE, 2003; QUINN et al., 2005).

As verotoxinas são semelhantes à toxina de shiga da Shigella dysenteriae estrutural, funcional e antigenicamente, inibindo a síntese protéica de células eucarióticas, após interação com a subunidade ribossômica 60S. O grau de lesão induzido está relacionado com a quantidade de receptores para essas toxinas (HIRSH; ZEE, 2003; QUINN et al., 2005).

O fator citotóxico necrosante é produzido por aproximadamente $40 \%$ das amostras de $E$. coli de infecções extra-intestinais, mas raramente é isolado de amostras fecais. Sua inoculação em coelhos resulta em uma dermonecrose acentuada (CAPRIOLI et al., 1983; JOHNSON, 1997).

Também podem ser produzidos pelo menos dois tipos de hemolisinas, alfa e beta, que lesam a membrana celular. A hemolisina alfa é secretada por muitas estirpes virulentas de E. coli, já a hemolisina beta fica ligada à célula, porém pouco se sabe sobre seu papel na virulência bacteriana. (HIRSH; ZEE, 2003; QUINN et al., 2005).

A resistência a antimicrobianos também constitui importante fator de virulência e pode ser transmitida a outros microrganismos, o que favorece a manutenção da resistência a diferentes fármacos. Tal fato dificulta conseqüentemente, a terapia antimicrobiana frente a infecções desencadeadas pelo agente (TRABULSI; TOLEDO, 1999).

É importante lembrar que identificar o fator de virulência não quer dizer que ele esteja sendo expresso no organismo hospedeiro (NAVEEN; MATHAI, 2005).

Há pelo menos seis categorias de E. coli causadoras de diarréia: E. coli enteropatogênica (EPEC), enterohemorrágica (EHEC), E. coli enterotoxigênica (ETEC), enteroinvasora (EIEC), enteroagregativa (EAggEC) e a de aderência difusa (DAEC) (TURNER et al., 2006). Além da $E$. coli uropatogênica (UPEC), que é provavelmente a maior causa de infecções no trato urinário de origem bacteriana no mundo (TRABULSI et al., 2005). 
Muitas bactérias, vírus e parasitas podem não estar associados a sinais clínicos, mas causar infecções latentes. Em função dessas infecções inaparentes pode-se ter um impacto considerável na experimentação sendo, portanto, muito importante o estudo microbiológico de animais de laboratório. É importante lembrar que alguns destes agentes podem também afetar o homem, e os animais de padrão sanitário convencional são os que possivelmente albergam microrganismos associados a zoonoses (BOOT; KOOPMAN; KUNSTYR, 1993).

Os animais de estimação podem constituir um sério risco de contaminação, devendo a prática de adquirir animais, principalmente em biotérios convencionais, ser desencorajada (BOOT; KOOPMAN; KUNSTYR, 1993).

Nos roedores e coelhos, espécies mais comumente utilizadas na experimentação, os agentes patogênicos são mais freqüentemente encontrados nos tratos respiratório e intestinal. Diferentes linhagens de uma espécie animal podem apresentar bases genéticas distintas quanto a suscetibilidade a agentes infecciosos, como ocorre com o camundongo da linhagem C57BL/6, que é mais susceptível a infecção por Streptobacillus moniliformis do que outras linhagens (BOOT; KOOPMAN; KUNSTYR, 1993).

Em 1998, Conlan e Perry estudaram a diferença de suscetibilidade das linhagens BALB/c, C57BL/6 e CD1 frente a inoculações de isolados de E.coli O157:H7, e verificaram que a primeira linhagem apresentou maior resistência à recolonização intestinal da bactéria do que as outras duas.

Recentes estudos demonstram que bactérias comensais de origem humana ou animal podem ser indicadoras da pressão seletiva a antimicrobianos e revelar o aparecimento da resistência destes em patógenos entéricos. Portanto, os estudos em bactérias comensais de animais saudáveis são muito importantes, uma vez que elas podem servir como reservatórios de genes de resistência a antimicrobianos e transferi-los para bactérias patogênicas (SAWANT et al.; 2007).

O teste de suscetibilidade a antibióticos é geralmente utilizado para bactérias de importância clínica, mas também pode ser útil na comparação de isolados em estudos epidemiológicos, pois quando a pressão seletiva a antibióticos muda, as estirpes bacterianas 
também podem mudar. $\mathrm{O}$ antibiograma é provavelmente o método laboratorial mais empregado para comparar diferentes estirpes de bactérias (FARMER, 1999). 


\section{REVISÃO DA LITERATURA}

Em todo o mundo os animais apresentam grande contribuição na melhoria da qualidade de vida, sendo muito utilizados em estudos para o desenvolvimento de novas tecnologias, fármacos e vacinas, além de desenvolver o conhecimento sobre a biologia das espécies e sua interação com o meio ambiente. Porém, a utilização de animais sadios, infectados ou geneticamente modificados expõe médicos veterinários, técnicos e pesquisadores a riscos inerentes às atividades realizadas em laboratórios e também em pesquisas de campo (SARMENTO, 2005).

Anteriormente, os animais de laboratório eram utilizados como "instrumento de trabalho", sem receber adequada atenção quanto à sua qualidade genética e sanitária. Hoje, porém exige-se que esses animais apresentem condições ideais, uma vez que são "reagentes biológicos" (ANDRADE, 2006).

Portanto, a pureza desses animais deve ser permanentemente fiscalizada ainda dentro do biotério, para que se atinja sua padronização que é um importante pré-requisito para que apresentem reações uniformes, e cujas pesquisas sejam passíveis de repetibilidade e reprodutibilidade de resultados experimentais (REHBINDER et al., 1996; CARDOSO, 2001).

Além disso, nos tempos atuais, um grande número de espécies animais é utilizado em pesquisas biomédicas, uma vez que estas possuem ou são potenciais hospedeiros de agentes zoonóticos. Em geral, relatos de zoonoses em decorrência do uso de animais em experimentação são raros, mas acredita-se que este número seja subestimado devido à falha de diagnóstico ou a não relação do local de trabalho com a doença (HANKENSON et al., 2003).

Os animais carreiam muitos microrganismos nos pêlos, pele, sistema respiratório, digestivo e urogenital. Alguns microrganismos são patogênicos, enquanto outros são considerados oportunistas, o que leva pessoas imunodeprimidas e gestantes terem acesso restrito a biotérios de experimentação (SARMENTO, 2005).

O manejo de animais oferece aos humanos os riscos de infecção e traumático, podendo este levar ao infeccioso, pois animais podem excretar ou aerossolizar microrganismos nas fezes, saliva ou urina o que daria origem a infecções. Pode ocorrer ainda inoculação de patógenos por mordeduras ou arranhaduras, além da transmissão direta pelo contato com sangue ou tecidos 
coletados em necropsias e a indireta por inalação de poeira originada das gaiolas e camas dos animais (CARDOSO, 2001).

Há uma tendência a considerar como risco à saúde humana principalmente as doenças relacionadas às zoonoses conhecidas. No entanto, todos os microrganismos devem ser considerados como potenciais oportunistas, até mesmo aqueles presentes em animais considerados "limpos", criados sob rigoroso sistema de barreiras sanitárias. Em condições favoráveis, os microrganismos podem causar infecções secundárias na pele, conjuntiva, trato respiratório ou digestório do homem (ANDRADE, 1996; BRAUMANS, 1999; SMITH, 1999).

$\mathrm{Na}$ maioria das vezes a transmissão de doenças pode ser evitada através de cuidados veterinários adequados e do cumprimento de normas e procedimentos pré-estabelecidos na criação e experimentação animal (ANDRADE, 2006).

Hankenson (2003) defende os 3 R's para as zoonoses de animais de laboratório, que são reconhecer que qualquer contato com os animais envolve um certo grau de risco ao manipulador, sendo necessário o treinamento e o uso de equipamentos de proteção individual (EPIs); relatar qualquer tipo de injúria ou exposição ao animal e responder rapidamente à situação, desinfetando o local atingido e seguindo as orientações médicas.

Em biotérios, boas práticas de higiene ajudam a prevenir a transmissão de doenças infecciosas e a manter a saúde tanto de manipuladores quanto dos animais. Além disso, a prevenção de doenças é uma importante contribuição ao bem estar animal (SMITH, 1999; MEZADRI; TOMAZ; AMARAL, 2004).

Segundo Teixeira e Valle (1996), os profissionais de Ciências Biológicas e Saúde são os que mais devem atender aos parâmetros preventivos ao longo da rotina laboratorial, conhecer todas as etapas dos seus protocolos e também os agentes que manipulam.

Dentre os microrganismos freqüentes no biotério estão os estafilococos coagulase negativos, que até pouco tempo atrás os eram considerados contaminantes de pouca importância clínica, porém atualmente são reconhecidos como importantes agentes de infecção humana e animal. Uma vez que ocorrem como comensais ou como contaminantes ambientais, as infecções podem ter origem endógena ou exógena, geralmente associadas a trauma, imunossupressão, infecções intercorrentes, entre outros (QUINN et al., 2005; TRABULSI et al., 2005). 
Já os micrococos são comumente encontrados no meio ambiente, e podem também ser isolados na pele do ser humano. Porém, raramente são associados a infecções, tais como abcessos, pneumonia, bacteremia , entre outros (TRABULSI et al., 2005).

Os estreptococos e enterococos são microrganismos bastante heterogêneos e isolados nos mais diferentes ambientes como integrantes da microbiota normal das vias aéreas superiores e do trato intestinal, podendo ser patógenos clássicos ou oportunistas. Existem relatos de enterococos causadores de infecção hospitalar, em que a amostra selecionada coloniza o trato gastrointestinal para em seguida causar uma infecção. A bactéria é facilmente transmitida pelas mãos dos funcionários, que se contaminam com o manuseio de equipamentos, roupas e objetos de pacientes (TRABULSI et al., 2005).

Já as espécies de Bacillus estão amplamente distribuídas pelo ambiente, principalmente em decorrência de sua capacidade de produzir esporos, que lhe confere grande resistência. Porém, a maioria das espécies é saprofítica e sem potencial patogênico (QUINN et al., 2005).

Medidas de contaminação bacteriana no ar do biotério podem ser realizadas de várias maneiras, geralmente expressadas pelo número de unidades formadoras de colônias (UFC), sendo que a concentração de microrganismos no ar pode ser um reflexo da densidade animal e da atividade exercida na sala (SMITH, 1999).

Os métodos de controle da qualidade do ar incluem sua filtração ou ainda o uso de sistemas de gaiolas microventiladas que ajudam a reduzir a presença de microrganismos. $\mathrm{O}$ uso de filtros no sistema de ventilação é a prática mais importante no controle da contaminação do ar no biotério,e muitos deles utilizam os chamados filtros "absolutos" ou HEPA (high efficiency particulate air), com o propósito de diminuir o risco da entrada de microrganismos indesejáveis (SMITH, 1999).

É essencial um sistema de ventilação com trocas regulares de ar nas salas, com controle de temperatura e umidade, que também ajuda a diminuir a presença de poluentes e de odores do amônia. Tal sistema deve ser capaz de retirar possíveis patógenos geralmente suspensos no ar e apresentar eficaz filtração para também reter partículas de poeira (MEZADRI; TOMAZ; AMARAL, 2004).

Essas medidas associadas a adequados procedimentos de limpeza e correta densidade populacional das gaiolas e salas ajudam a reduzir o número de partículas e a contaminação do ar. Padrões mínimos de controle no macro e microambientes estabelecem lugares com maior 
estabilidade, mais econômicos, sem doenças e cientificamente melhor aceitos, o que confere confiabilidade nos resultados experimentais (CLOUGH, 1999; SMITH, 1999; MEZADRI; TOMAZ; AMARAL, 2004).

O monitoramento da qualidade do ar é tradicionalmente utilizado para determinar a concentração de contaminantes e avaliar o risco aos indivíduos expostos. No entanto, apenas esta medida não garante que a área está livre de contaminação, pois os microrganismos podem ser reaerossolizados. Sendo assim, superfícies utilizadas no local também devem ser pesquisadas quanto a sua contaminação (STETZENBACH; BUTTNER; CRUZ, 2004).

Deve-se então assegurar o padrão sanitário dos animais e zelar pelo seu bom estado de saúde, e pelas melhorias necessárias nas condições ambientais como: controle de temperatura, de trocas de ar das salas para retirada de gases, da umidade relativa do ar, redução de ruídos, separação das diferentes espécies em diferentes recintos, rígido controle no trânsito de pessoal e treinamento prévio de funcionários que irão manipular os animais. Tais medidas visam promover conforto ambiental aos animais e evitar ao máximo a entrada de agentes infecciosos na colônia (MERUSSE; LAPICHIK, 1996).

Num estudo de Gilioli (2003) sobre biotérios de 18 instituições brasileiras constatou-se que infecções de animais por vírus, bactérias e parasitas são comuns na maioria dos biotérios. Como resultante, o autor comenta a necessidade de melhoria na infra-estrutura das edificações para que se alcance a melhoria na qualidade dos animais produzidos e utilizados em pesquisa no território nacional.

É importante considerar que a variedade genética, estabelecida pelo grande número de linhagens existentes, leva a extremos de suscetibilidade entre elas, quando expostas aos mesmos agentes e nas mesmas condições ambientais. Ocorre por exemplo com o vírus ectromélia, que causa alta mortalidade em animais CBA, C3H, DBA/2 e BALB/c, enquanto que linhagens como a C57BL/6 e C57BL/10 são praticamente resistentes a este agente. Então, controlar a qualidade sanitária destas colônias tem sido uma das tarefas mais exploradas pela ciência de animais de laboratório (MAHLER; NICLAS, 2004; PEREIRA, 2006).

Programas de monitoramento da saúde de animais de laboratório têm utilizado métodos moleculares como suplemento às técnicas tradicionais, sendo a mais comum a técnica de reação em cadeia da polimerase (PCR). Uma de suas maiores vantagens é a alta sensibilidade analítica, além de ser um método rápido (MAHLER; NICLAS, 2004). 
A manutenção dos animais em biotérios requer um trabalho rígido de manejo, higienização rotineira do ambiente onde vivem, se alimentam e produzem dejetos. O controle da saúde dos animais pode parecer bastante dispendioso, porém é totalmente justificável por contribuir na exatidão dos experimentos e obtenção de informações por eles geradas. Tal controle permite mais rápida detecção de agentes que porventura contaminem os animais, o que possibilita que medidas corretivas sejam realizadas mais precocemente. (REHBINDER et al., 1996; SMITH, 1999; SARMENTO, 2005).

Dentre os microorganismos contaminantes de animais de laboratório estão aqueles que afetam o trato intestinal, causando morbidade e mortalidade consideráveis. A $E$. coli é um dos agentes mais disseminados em várias colônias de biotérios e anteriormente todas as suas estirpes causadoras de diarréia eram chamadas de enteropatogênicas. Com a evolução das pesquisas houve uma maior elucidação sobre seus mecanismos de patogenicidade o que permitiu que essas estirpes fossem reagrupadas. EPEC e ETEC são as mais importantes em termos de números de episódios de diarréia no mundo, porém a ocorrência de casos EHEC tem se tornado mais significante em países desenvolvidos (CLARKE, 2001).

\section{E. coli ENTEROPATOGÊNICA (EPEC)}

É uma importante categoria de E. coli causadora de diarréia, sendo associada à diarréia crônica, que leva a seqüelas como má absorção, má nutrição, perda de peso e retardo no crescimento. Também é uma das mais comuns causas de diarréia em crianças de países em desenvolvimento. (NATARO; KAPER, 1998; BOPP et al., 1999) . 


\section{Patogênese}

A principal característica das infecções pela EPEC é a lesão de fixação e esfacelamento (A/E), que pode ser observada através da biopsia intestinal de homens e animais, sendo também reproduzida em cultura de células. Uma lesão similar também pode ser encontrada em modelos animais ou cultura de células infectadas pela E. coli enterohemorrágica (EHEC). A patogênese inicial da EPEC e da EHEC pode ser similar em termos de danos ao epitélio do trato gastro intestinal, mas há repercussão mais grave na EHEC. (NATARO; KAPER, 1998; ROE; GALLY, 2000).

Bactérias como Citrobacter rodentium (C. freundii biotipo 4280), que causam hiperplasia colônica em camundongos, também podem provocar a lesão A/E. Algumas etapas são seguidas para que ocorra esta lesão, sendo elas a aderência localizada, transdução e aderência íntima da bactéria com a borda em escova da mucosa intestinal (NATARO; KAPER, 1998; ROE; GALLY, 2000).

Observou-se que a $E$. coli $\mathrm{O} 127: \mathrm{H} 6$ era capaz de aderir às células devido à presença de um plasmídio de 60MDa, que posteriormente foi chamado de fator de aderência de EPEC (EAF), sendo este um fator muito importante no seu diagnóstico. Outro fator responsável pela aderência da bactéria é uma fímbria produzida por estirpes de EPEC que tendem a se agregar e formar "pacotes", sendo então conhecida como "pilus formadores de pacotes" (BFP) (NATARO; KAPER, 1998).

A aderência íntima da EPEC às células se dá através de uma proteína de membrana externa chamada intimina, que é codificada pelo gene eae (E. coli attaching and effacing). Ele está presente em todas as estirpes de EPEC, EHEC, $C$. rodentium e $H$. alvei, capazes de produzir a lesão A/E, mas ausente nas estirpes de bactérias da microbiota normal, ETEC e outras (NATARO; KAPER, 1998; DONNENBERG; WHITTAM, 2001).

A grande perda de microvilosidades devido à lesão $\mathrm{A} / \mathrm{E}$ pode levar a diarréia devido a má absorção. No entanto, o período de incubação em voluntários adultos é curto (por volta de 2,9 horas), o que sugere a presença de outro mecanismo que leve a diarréia. Uma possibilidade é a estimulação de secreção de íons, já que a infecção pode levar a uma perda de resistência da 
monocamada de células intestinais, que provocaria um aumento de permeabilidade (NATARO; KAPER, 1998).

Para que a lesão A/E ocorra, é necessário um elemento genético conhecido como locus de esfacelamento do enterócito (LEE), que se localiza em uma ilha de patogenicidade. Ao clonar o gene que codifica LEE em uma $E$. coli não patogênica, esta passa a provocar a lesão $\mathrm{A} / \mathrm{E}$ (DONNENBERG; WHITTAM, 2001).

Infecções por EPEC induzem a um aumento intracelular de cálcio e acredita-se que este aumento provoque mudanças no citoesqueleto da célula afetada. Além disso, altas taxas de cálcio intracelular podem inibir a absorção de $\mathrm{Na}^{+}$e $\mathrm{Cl}^{-}$e estimular a secreção de $\mathrm{Cl}^{-}$pelos enterócitos. Tais dados sugerem que as mudanças na secreção de cloro podem mediar a resposta secretória intestinal na EPEC (NATARO; KAPER, 1998).

\section{Epidemiologia}

A infecção por EPEC ocorre principalmente em crianças com menos de dois anos de idade, sendo que as razões para a maior resistência dos adultos e crianças mais velhas não são conhecidas. Porém, a perda de receptores específicos com a idade é uma possibilidade. A mesma restrição pela idade é observada nos animais (NATARO; KAPER, 1998).

A transmissão da bactéria se dá pela via fecal-oral, e pode ter como reservatório crianças saudáveis ou doentes, além de adultos assintomáticos. Animais como coelhos, porcos e cães podem carrear a bactéria, porém geralmente estas EPEC são consideradas espécie-específicas, não apresentando então patogenicidade ao homem (NATARO; KAPER, 1998; ROE; GALLY, 2000). 


\section{Considerações clínicas}

Além da diarréia aquosa, vômito e febre, leucócitos fecais também podem ser encontrados. A biopsia do intestino delgado pode apresentar bactérias aderidas à parede e a clássica lesão A/E. Recomenda-se hidratação para corrigir o desequilíbrio hidro-eletrolítico e antibioticoterapia. Porém, com a grande variedade de antibióticos que têm sido usada para o tratamento da diarréia, a múltipla resistência é comum (NATARO; KAPER, 1998).

\section{Detecção e diagnóstico}

A característica mais importante para o diagnóstico da EPEC é a presença da lesão A/E, sem a presença da shiga toxina, uma vez que a EHEC também pode causar este tipo de alteração histológica. Primers para a PCR têm sido desenvolvidos para avaliar a presença de três características da EPEC: capacidade de provocar a lesão A/E (pelo gene eae), plasmídio EAF e ausência da shiga toxina (NATARO; KAPER, 1998).

E. coli ENTEROHEMORRÁGICA (EHEC).

O reconhecimento da EHEC como agente patogênico teve início em 1983, quando Riley et al. investigavam dois surtos de doença gastrointestinal caracterizados por dor abdominal e diarréia aquosa seguida de sangue. Esta doença foi denominada de colite hemorrágica (HC) e foi associada à ingestão de hambúrgueres mal cozidos. A cultura das fezes isolou uma rara estirpe de E. coli $(\mathrm{O} 157: \mathrm{H} 7)$.

No mesmo ano, ocorreram relatos de casos de síndrome hemolítica urêmica (HUS) com E. coli produtora de citotoxina isolada nas fezes. A HUS, caracterizada por falha renal aguda, 
trombocitopenia e anemia hemolítica microangiopática, seria também precedida por diarréia sanguinolenta (NATARO; KAPER, 1998; DONNENBERG; WHITTAM, 2001).

O’Brien e colaboradores (1980) observaram que certas amostras de E. coli eram tóxicas para células HeLa e que esta atividade poderia ser neutralizada pela antitoxina preparada contra a toxina de Shigella dysenteriae 1. Mais tarde, o autor relatou que a toxina shiga like era a mesma produzida pela O157:H7 descrita por Riley.

Os sorotipos O157:H7 e O157 não móvel produzem a toxina Shiga símile, e são os sorotipos mais comumente encontrados nas diarréias humanas causadas pela E. coli na América do Norte e Europa (BOPP et al., 1999).

A E. coli $\mathrm{O} 157: \mathrm{H} 7$ pode causar dor abdominal, febre, além da síndrome hemolítica urêmica. Ele é o mais conhecido e virulento patógeno deste grupo, sendo um habitante ocasional dos tratos intestinais de animais, especialmente bovinos. O sorotipo O157 é responsável por $80 \%$ dos casos de síndrome hemolítico-urêmica nos Estados Unidos da América. Sua transmissão pode ocorrer através da ingestão de vegetais crus e saladas contaminadas, carne assada, leite cru e água não tratada. Como a dose infectante é muito baixa, a transmissão entre indivíduos ocorre facilmente (BOPP et al., 1999; TORTORA; FUNKE; CASE, 2000).

\section{Patogênese}

Geralmente ocorre infecção após a ingestão de carne moída contaminada, principalmente de origem bovina, levando a diarréia sanguinolenta. Esta estirpe produz lesões de fixação e esfacelamento (A/E), além de diarréia hemorrágica. Após sua aderência, produz a toxina Stx que afeta as células endoteliais, provocando lesão e perda da integridade. Os efeitos da toxina podem ser locais ou sistêmicos, e leva à síndrome hemolítica urêmica em humanos. Os camundongos têm sido utilizados freqüentemente como modelos em estudos para investigar doenças causadas pela EHEC, através de infecção oral (PALERMO-NETO; ALMEIDA, 2002; HIRSH; ZEE, 2003; NAGANO et al., 2003).

A histopatologia clássica da EHEC O157:H7 envolve hemorragia e edema da lâmina própria, podendo haver necrose focal e infiltração de neutrófilos. Também podem ser observadas 
as lesões no início da infecção, antes que os efeitos citotóxicos da Stx ocorram. Como na EPEC, a ilha de patogenicidade LEE também confere a capacidade de provocar este tipo de lesão a EHEC (apresentam 93,9\% de homologia). Ela ocorre devido a mudanças no citoesqueleto celular, esfacelando as microvilosidades com promoção de íntima ligação entre a bactéria e a membrana celular (NATARO; KAPER, 1998; ROE; GALLY, 2000; DONNENBERG; WHITTAM, 2001; CAPRIOLI et al., 2005).

\section{Shiga-toxina (Stx)}

Esta toxina pode ser dividida em dois grupos, Stx 1 e Stx 2, sendo que a primeira é idêntica a Shiga toxina produzida pela $S$. dysenteriae e a segunda apresenta menos de $60 \%$ de similaridade com Stx 1. É formada por uma subunidade A e cinco subunidades B, que se ligam ao receptor Gb3 presente na superfície de células eucarióticas (NATARO; KAPER, 1998; CAPRIOLI et al., 2005).

A subunidade A é translocada para o citoplasma, onde age na subunidade ribossomal 60S, inibindo a síntese de proteínas. A toxina é capaz de atingir pequenos vasos sanguíneos que suprem o intestino, rim e outras vísceras. Como resultado, ocorre a morte dessas células ou de qualquer outra que apresente o receptor Gb3 (NATARO; KAPER, 1998; CAPRIOLI et al., 2005; RAZZAQ, 2006).

Um possível mecanismo para a secreção de fluidos que ocorre em resposta a Stx envolve a destruição da capacidade absortiva das microvilosidades intestinais. Em coelhos, os receptores Gb3 apresentam-se em maior quantidade nas células das vilosidades intestinais do que nas secretórias, portanto a morte de células absortivas leva a um desequilíbrio absorção-secreção intestinal. Porém, a importância da toxina na doença difere de acordo com o modelo animal utilizado. Em leitões, Stx não provoca nenhuma diferença na diarréia. Também no coelho, a infecção pela O157:H7 sem a toxina levou às mesmas mudanças na absorção de íons que as provocadas pela bactéria com Stx (NATARO; KAPER, 1998). 
Acredita-se que a toxina danifique as células glomerulares, ao provocar a oclusão de sua microvasculatura com plaquetas e fibrina. Essas mudanças isquêmicas manifestam-se danificando os rins (NATARO; KAPER, 1998; RAZZAQ, 2006).

Experimentos com camundongos sugerem que Stx 2 é um citotóxico mais potente que Stx 1. Porém, Stx 2 não é uma classe homogênea, sendo observada a existência de variantes com subunidades B idênticas, mas com pequenas variações na subunidade A, que levam a diferentes graus de letalidade nos camundongos (NATARO; KAPER, 1998).

\section{Enterohemolisina}

Um plasmídio de 60 MDa comumente encontrado em estirpes de EHEC O157:H7, contem genes que codificam a hemolisina (hly). Este apresenta $60 \%$ de identidade com genes da hemolisina da E. coli uropatogênica. O papel desta toxina ainda não está bem claro, mas acreditase que a lise dos enterócitos promoveria uma maior multiplicação de E. coli, servindo como fonte de ferro (NATARO; KAPER, 1998; CAPRIOLI et al., 2005).

\section{Epidemiologia}

Muitos casos da doença ocorrem após a ingestão de alimentos contaminados, particularmente de origem bovina, mas também pode ocorrer através da água ou transmissão pessoa-pessoa. Acredita-se que a doença ocorra com uma dose infectante muito baixa (menos de 100 células), mas pessoas podem carrear a EHEC sem apresentar sintomas (NATARO; KAPER, 1998; CAPRIOLI et al., 2005).

E. coli produtoras de Stx podem ser isoladas da microbiota fecal de uma grande variedade de animais, como bovinos, ovinos, caprinos, suínos, cães, gatos e galinhas. No entanto, a maioria das estirpes não é O157:H7 e possuem patogenicidade questionável. O animal mais importante, 
na ocorrência da infecção humana por esta EHEC, é o bovino. A presença da EHEC nos excretas desta espécie parece estar associada à idade, tendo sido isolada em menos de 1,5\% dos bezerros com menos de dois meses e entre 1,5 e $5 \%$ nos animais entre dois e quatro meses de idade (NATARO; KAPER, 1998; CAPRIOLI et al., 2005; RAZZAQ, 2006).

A vigilância soroepidemiológica demonstra que a concentração de anticorpos anti O157 é três vezes maior em canadenses que vivem em fazendas do que naqueles que vivem em áreas urbanas e seis vezes maior quando se trata de anticorpos anti Stx 1. EHEC O157 foi isolada em animais de companhia que vivem em ambientes rurais, além de ter sido recentemente descrita também em coelhos domésticos e selvagens. Com base nestas constatações, a importância dos animais como fonte de infecção para humanos deve ser estudada (NATARO; KAPER, 1998; CAPRIOLI et al., 2005).

Karpman e colaboradores, em 1997 observaram que camundongos inoculados com estirpes Stx 2 positivas desenvolveram sintomas neurológicos e maior freqüência de sintomas sistêmicos do que aqueles inoculados com estirpes negativas. No entanto, os animais não apresentaram lesões vasculares no glomérulo, característicos das HUS humanas.

$\mathrm{O}$ isolamento da EHEC em um grande espectro de espécies animais, que podem ser hospedeiros naturais ou meramente vetores ocasionais, sugere que devem ser conduzidas investigações também com animais previamente não descritos como reservatórios, assim como também com alimentos e no ambiente (CAPRIOLI et al., 2005).

\section{Considerações clínicas}

A estirpe O157:H7 está presente na maior parte das observações clínicas feitas pela EHEC. Outras podem causar sintomas parecidos, mas com menos diarréia sanguinolenta e menos HUS (NATARO; KAPER, 1998).

O período de incubação pode variar entre três e oito dias, com sintomas iniciais como diarréia sem sangue evoluindo para dor abdominal com ou sem febre, vômitos e diarréia sanguinolenta. Na maioria dos casos, a diarréia com sangue não deixa seqüelas, mas em 10\% dos pacientes jovens pode evoluir para HUS (NATARO; KAPER, 1998). 
Apesar da EHEC ser sensível a muitos antibióticos, não existem estudos que indiquem que há melhora da doença com a antibioticoterapia (NATARO; KAPER, 1998).

\section{Diagnóstico e detecção}

Existem três categorias de diagnóstico para EHEC: isolamento da E. coli de amostras fecais, detecção de organismos produtores de Stx ou isolamento de Stx fecal; detecção de níveis elevados de anticorpos anti O157 (NATARO; KAPER, 1998).

Não há características bioquímicas comuns associadas à maioria das estirpes de EHEC. Sabe-se que estirpes de 0157:H7 não fermentam D-sorbitol rapidamente, em contraste com outras $75-94 \%$ das E. coli (NATARO; KAPER, 1998).

O meio de cultura mais utilizado para isolamento da O157:H7 é o SMAC ágar, que contém $1 \%$ de sorbitol ao invés da lactose, utilizada no meio MacConkey. Colônias não fermentadoras de sorbitol são indicativas da EHEC O157:H7 (NATARO; KAPER, 1998).

Muitas técnicas de PCR têm sido desenvolvidas para detectar os genes que codificam Stx. Essas técnicas são muito sensíveis e específicas quando a colônia bacteriana é utilizada, e apresenta piores resultados com a amostra fecal total (NATARO; KAPER, 1998).

Para investigar a epidemiologia das infecções pela O157:H7, outra técnica utilizada é a eletroforese em gel de campo pulsátil, técnica bastante sensível, porém trabalhosa (NATARO; KAPER, 1998).

E. coli ENTEROTOXIGÊNICA (ETEC)

Trata-se de uma importante causa de diarréia em países em desenvolvimento, mas aparece com cada vez mais freqüência em países como Estados Unidos da América e Japão. A ETEC é a causa mais comum de diarréia por E. coli em humanos no mundo, sendo provocada pelo 
consumo de água e alimentos contaminados. Ocorre com maior frequiência nos meses úmidos, quando a multiplicação da bactéria é mais eficiente (NATARO; KAPER, 1998; BOPP et al., 1999; TURNER et al., 2006).

Foi primeiramente descrita por provocar diarréia em leitões, causando uma infecção letal. Já sua primeira descrição em humanos ocorreu em 1956 em Calcutá, quando pesquisadores injetaram isolados da bactéria oriundos de fezes de crianças com doença semelhante à cólera em alça ileal ligada de coelho. Como resultado, encontrou-se grande quantidade de fluido acumulado na alça, similar a vista com Vibrio cholerae (NATARO; KAPER, 1998; QUADRI et al., 2005).

As estirpes que causam a diarréia enterotoxigênica podem provocar distúrbio funcional de células epiteliais intestinais, que leva a diarréia em leitões, bezerros e cordeiros recém-nascidos. Elas produzem adesinas resistentes a manose, capazes de se ligarem a glicoproteínas presentes na superfície das células epiteliais do jejuno e íleo. Além disso, estas estirpes são capazes de sintetizar enterotoxinas ST, LT ou ambas. Os sintomas mais comuns são diarréia, dor abdominal, que pode ou não estar acompanhada de náusea, dor de cabeça, vômito e febre (AL-MAJALI et al., 1999; BOPP et al., 1999; HIRSH; ZEE, 2003; QUINN et al., 2005).

Após a ingestão, a estirpe enterotoxigênica adere à célula-alvo, multiplica-se e secreta endotoxinas, que causam um acúmulo de líquidos e eletrólitos na luz intestinal, provocando diarréia, desidratação e desequilíbrio eletrolítico (HIRSH; ZEE, 2003).

Verificou-se que os receptores para a STa no intestino de humanos e camundongos jovens encontram-se em maior densidade, o que torna crianças e esses animais mais susceptíveis à doença, devendo-se evitar que eles convivam no mesmo local (AL-MAJALI et al., 1999).

Ela está associada a duas síndromes: diarréia em crianças de países em desenvolvimento e diarréia dos viajantes, tendo como padrão epidemiológico o desenvolvimento de imunidade nos indivíduos expostos, eliminação de grande número de ETEC pelas fezes, mesmo nos indivíduos assintomáticos e alta dose infectante (NATARO; KAPER, 1998).

Estima-se que este patógeno seja responsável por 650 milhões de casos por ano em países desenvolvidos, que resulta em 800 mil mortes, principalmente de crianças. Ainda, seu alto nível de morbidade em humanos tem implicações também na pecuária, uma vez que este é o maior patógeno para o gado e leitões (TURNER et al., 2006). 
Em um estudo realizado em Bangladesh, a ETEC foi isolada de pacientes com diarréia e em $32 \%$ das águas de rios e lagos. Comparando-se as estirpes através da eletroforese em gel de campo pulsátil, observou-se que se tratava exatamente da mesma bactéria. Conclui-se assim que a água é uma importante fonte de infecção da ETEC (QUADRI et al., 2005).

Esta estirpe, assim como outras bactérias, possui uma estratégia básica para infecção, que consiste na aderência a célula hospedeira, multiplicação, evasão das defesas e danos ao hospedeiro. Esses danos são mediados por fatores de virulência como os fatores de colonização (CFs) ou uma ou mais enterotoxinas, ambos encontrados em plasmídios (TURNER et al., 2006).

Observou-se que a resistência a antibióticos e habilidade de produzir enterotoxinas são freqüentemente transferidas juntas, o que leva a crer que o uso de antibióticos pode provocar um aumento de estirpes enterotoxigênicas. Plasmídios que codificam a resistência a antibióticos e ST podem ser transferidos in vitro e in vivo em camundongo neonato, sugerindo que a pressão seletiva do antibiótico pode levar a um aumento na freqüência de ETEC (QUADRI et al., 2005).

Ela provoca então uma doença tipicamente abrupta, com curto período de incubação (14 a 50 horas), diarréia aquosa sem sangue, muco ou pus, com febre e vômito na minoria dos casos. A diarréia pode ser suave e breve ou severa, similar à vista em infecções pelo $V$. cholerae (NATARO; KAPER, 1998).

As estirpes de ETEC foram um dos primeiros agentes patogênicos a terem técnicas moleculares desenvolvidas para seu diagnóstico. Em 1982, encontrou-se probes de DNA úteis na detecção de genes que codificam LT e ST nas fezes e ambiente. Desde então, muitos avanços no diagnóstico da ETEC têm sido realizados, e as técnicas genéticas têm atraído mais atenção (NATARO; KAPER, 1998).

A PCR para detecção de ETEC apresenta-se bastante sensível e específica quando utilizada diretamente em amostras clínicas ou colônias bacterianas isoladas, sendo também utilizada a multiplex PCR, na qual diferentes primers são utilizados na mesma reação, com o objetivo de detectar várias seqüências de DNA em um único teste (NATARO; KAPER, 1998; QUADRI et al., 2005). 


\section{Fatores de colonização}

Fatores de colonização (CFs) são estruturas proteináceas de superfície que permitem à bactéria se fixar na mucosa intestinal do hospedeiro. Mais de $20 \mathrm{CFs}$ foram identificados e caracterizados de forma distinta entre humanos e animais. Para diferenciá-los, os fatores de animais foram designados pela letra F, sendo os mais comuns F4, F5 e F6, também referidos como K88, K99 e 987P (TURNER et al., 2006).

A adesão da ETEC ocorre então através das fimbrias (ou pili), que se arranjam ao seu redor e podem ter múltiplas morfologias no mesmo organismo. Elas conferem ainda espécieespecificidade ao patógeno, como as estirpes expressando K99, que são patogênicas para bezerros, cordeiros e leitões, enquanto outras com K88 só afetam suínas (NATARO; KAPER, 1998).

As infecções decrescem após a infância com novo aumento em idades avançadas, talvez devido a fatores ambientais, genéticos e imunológicos. Dados obtidos de estudos em animais indicam mudanças com a idade com relação à presença de receptores K99 nas células intestinais (QUADRI et al., 2005).

A linhagem de camundongo mais utilizada como modelo para estudos da ETEC é o Swiss OF1, mas muitas outras linhagens heterogênicas e isogênicas também têm sido testadas. A influência da linhagem do camundongo na suscetibilidade a bactéria é muito importante e já foi relatada. A inoculação de 10 ufc da ETEC é suficiente para causar diarréia e morte em camundongos neonatos $\mathrm{OF} 1$ e CD-1, sendo o camundongo DBA/2 o mais resistente à bactéria (DUCHET-SUCHAUX, 1999).

Visando criar um modelo para estudos da ETEC humana, Allen, Randolph e Fleekenstein, em 2006 desafiaram o camundongo heterogênico CD-1 ao inocular oralmente $1 \times 10^{8}$ ufc da estirpe humana H10407 ou AAEC191-A, bactérias que possuem e não possuem fímbrias respectivamente. Como resultado, encontraram mais bactérias na mucosa do intestino da estirpe H10407, principalmente no íleo. 


\section{Toxinas termoestáveis (ST)}

São toxinas pequenas, com múltiplos resíduos de cisteína, cujas pontes dissulfídicas levam a sua termoestabilidade, e mantém assim sua ação tóxica mesmo depois de submetida à temperatura de $100^{\circ} \mathrm{C}$ por 30 minutos. Há duas classes de STs, (Sta e STb) que diferem em estrutura e mecanismo de ação, mas os genes para ambas são encontrados em plasmídios. (NATARO; KAPER, 1998).

A STa é categorizada de acordo com o hospedeiro em que é isolada, sendo STp (ou STIa) encontrada em suínos, embora algumas variantes já tenham sido isoladas em humanos e bovinos, e STh (ou STIb), encontrada em infecções humanas. A STa nessa estirpe de E. coli é considerada a maior causadora de diarréia em animais jovens. (NATARO; KAPER, 1998; TURNER et al., 2006).

Seu receptor é a guanilato ciclase C (GC-C), encontrada na membrana apical das células epiteliais do intestino. A ligação da toxina ao receptor estimula a atividade da guanilato ciclase, que provoca um aumento dos níveis intracelulares de GMP cíclico. Esta atividade resulta em um aumento da secreção de cloro ou inibição da absorção de $\mathrm{NaCl}$, que leva a um aumento de secreção intestinal (NATARO; KAPER, 1998).

Já a STb induz danos histológicos no epitélio intestinal, caracterizado pela atrofia parcial até a perda de suas vilosidades. Sabe-se que esta toxina estimula a secreção de bicarbonato pelas células intestinais e aumenta o cálcio intracelular (NATARO; KAPER, 1998).

A ST era inicialmente detectada através do teste de alça ileal ligada de coelho, mas o custo e a necessidade de padronização levaram este método a ser substituído pelo ensaio em camundongo lactente. Muitos imunoensaios têm sido desenvolvidos para a detecção de ST, como o radioimunoensaio e enzyme-linked immunosorbent assay (ELISA), ambos com resultados semelhantes aos obtidos pelo teste em camundongo lactente (NATARO; KAPER, 1998). 


\section{Toxinas termolábeis (LT)}

São assim chamadas por serem inativadas quando submetidas a uma temperatura de $60^{\circ} \mathrm{C}$ por 30 minutos, sendo provavelmente as toxinas mais bem caracterizadas dentre as ETEC devido a sua grande homologia com a citotoxina colérica (CT). As LTs podem ser divididas em dois grupos: LT-I e LT-II, cujos genes (elt ou etx) residem em plasmídios que também podem conter genes que codificam ST (NATARO; KAPER, 1998; TURNER et al., 2006).

A LT-I é uma toxina composta por uma subunidade A de $28 \mathrm{kDa}$ e cinco subunidades B idênticas de 11,5 kDa. Ela está fortemente relacionada à CT, com 75\% de similaridade com a subunidade A e 77\% com a subunidade B (NATARO; KAPER, 1998; TURNER et al., 2006).

A subunidade B se liga fortemente ao gangliosídeo GM1 ou fracamente a GD1b, e a subunidade A é a que apresenta atividade toxigênica. Então, após a ligação da membrana da célula hospedeira, a toxina é endocitada e traslocada pela célula. O alvo da toxina é a adenilato ciclase, localizada na membrana basolateral da célula epitelial intestinal, que é estimulada (NATARO; KAPER, 1998).

Este mecanismo leva a um aumento do AMP cíclico intracelular, que leva a um aumento da fosforilação dos canais de cloro, que estimulam a secreção de $\mathrm{Cl}^{-}$e inibem a absorção de $\mathrm{NaCl}$. O aumento luminal dos íons leva ao transporte passivo de água, que resulta em uma diarréia osmótica (NATARO; KAPER, 1998).

A toxina LT-II apresenta 55 a 57\% de identidade com a subunidade A de LT-I. Ela possui duas variantes antigênicas, a LT-IIa e LT-IIb, com mecanismo de ação semelhante à LT-I, porém utilizando o receptor GD1 ao invés do GM1 (NATARO; KAPER, 1998).

Estirpes de ETEC que expressam apenas LT são consideradas de menor importância como patógeno, principalmente porque são mais freqüentemente isoladas de pessoas saudáveis do que de pacientes. Este fato pode estar relacionado com a baixa prevalência de CFs nas estirpes produtoras de LT. Assim, em muitos estudos epidemiológicos, os CFs são encontrados em menos de $10 \%$ das ETEC que produzem a toxina e em $60 \%$ das que produzem ST ou ST/LT (QUADRI et al., 2005).

Recentes estudos com suínos demonstraram que a elaboração da LT pode fornecer vantagens para que a bactéria se estabeleça no intestino do hospedeiro. Para investigar esta 
hipótese, Allen, Randolph e Fleekenstein, em 2006 desafiaram camundongos CD-1 com ETECs H10407 e jf571, estirpes que não possuem e possuem uma mutação no gene que codifica a subunidade A de LT, respectivamente. Ambas as estirpes foram capazes de colonizar o intestino, porém a primeira mostrou-se mais eficiente, o que indica que a LT pode facilitar a colonização da mucosa intestinal.

Uma possível explicação para este fato pode ser a alteração estrutural da célula hospedeira provocada pela toxina, uma vez que o aumento intracelular de AMP cíclico pode levar a maior produção de um ou mais receptores para a bactéria. Além disso, o aumento do AMP cíclico inibe a ativação de várias citocinas, como o fator de necrose tumoral alfa e a interleucina 8, o que altera a resposta do hospedeiro a infecção (ALLEN; RANDOLPH; FLEEKENSTEIN, 2006).

Estudos com camundongos neonatos mostraram que há considerável variação de suscetibilidade a ETEC e suas toxinas entre diferentes linhagens de camundongos isogênicos, indicando que fatores genéticos do hospedeiro podem interferir nas infecções por ETEC (ALLEN; RANDOLPH; FLEEKENSTEIN, 2006).

O teste tradicional para detecção da LT envolve o uso de cultura de célula adrenal Y1 ou do ovário de hamster chinês (CHO). Porém, ensaios imunológicos são mais simples de serem implementados em laboratórios clínicos (NATARO; KAPER, 1998).

\section{EAST-1}

É uma toxina de 38 aminoácidos, pouco caracterizada em termos de função e contribuição a ETEC. Ela foi originalmente isolada na estirpe enteroagregativa 17-2, mas também identificada em outras E. coli, incluindo a ETEC de humanos e animais (TURNER et al., 2006).

Ensaios in vivo demonstraram que EAST-1 induz o acúmulo de fluidos em camundongos neonatos e em modelos de alça ileal ligada de coelho. Esta toxina demonstrou similaridades com Sta, entre elas a formação de pontes dissulfídicas, que confere sua termoestabilidade, a ativação da produção de GMP cíclico e a utilização do mesmo receptor nas células eucarióticas. No entanto, anticorpos anti Sta não são capazes de agir contra EAST-1 (TURNER et al., 2006). 
E. coli ENTEROINVASORA (EIEC)

A patogenicidade deste grupo, regulada tanto por genes cromossomais quanto plasmidiais, consiste na capacidade de invasão de células epiteliais e conseqüente infecção de células adjacentes, principalmente na mucosa do cólon (TRABULSI et al. , 2005).

Ocorre penetração do epitélio celular, lise do vacúolo endocítico, multiplicação intracelular, movimentos pelo citoplasma e extensão ao epitélio celular adjacente. Quando a infecção é severa, esta sequiência de eventos leva a uma forte reação inflamatória com grande ulceração (NATARO; KAPER, 1998).

É uma bactéria bioquímica e geneticamente similar a Shigella spp, sendo ambas geralmente lisina descarboxilase negativas, imóveis e lactose negativas. Além disso, seu mecanismo de ação não está muito claro, mas acredita-se que também seja similar a Shigella spp (NATARO; KAPER, 1998).

Acredita-se que muitos casos de diarréia por EIEC são erroneamente identificados como por Shigella spp ou E. coli não patogênica. A infecção ocorre através de alimentos contaminados, mas a transmissão pessoa-pessoa também pode ocorrer (NATARO; KAPER, 1998).

A bactéria geralmente tem capacidade de invadir as células do cólon e causar diarréia aquosa, que pode ser indistinguível daquela provocada pela ETEC, porém é bem menos freqüente que esta ou EPEC. Pode ocorrer ainda disenteria com sangue, muco e leucócitos nas fezes. (BOPP et al., 1999; NATARO; KAPER, 1998).

Seu diagnóstico clássico é através do teste de Séreny, no qual se observa a habilidade da bactéria de invadir e se espalhar no epitélio celular, levando a ceratoconjuntivite no cobaio. (NATARO; KAPER, 1998).

E. coli ENTEROAGREGATIVA (EAggEC)

Trata-se de um grupo heterogêneo, com grande variedade de fatores de virulência, como a enterotoxina termo estável similar a produzida pela ETEC, hemolisinas e outras toxinas, além de 
vários tipos de fímbrias e proteínas de membrana externa, que podem estar envolvidas no processo de adesão. O papel desses fatores na produção da doença não está claro (LAW; CHART, 1998).

Estirpes de EAggEC são definidas como $E$. coli que se aderem às células Hep-2 de forma agregativa, sendo este padrão válido para estirpes patogênicas ou não (NATARO; KAPER, 1998; YATSUYANAGI et al., 2002).

Esta bactéria estimula a secreção mucóide e se liga a ela, formando um biofilme, talvez como forma de causar uma colonização persistente e diarréia. No Brasil, esta bactéria é responsável por $68 \%$ dos casos da doença. Tem sido associada à diarréia persistente em crianças, mas pouco se sabe sobre sua patogênese (NATARO; KAPER, 1998; SAVARIANO et al., 1991).

Infecções experimentais realizadas em alça ileal ligada de ratos e coelhos demonstraram encurtamento das vilosidades, necrose hemorrágica de sua extremidade, edema e infiltrado mononuclear da submucosa (LAW; CHART, 1998; NATARO; KAPER, 1998).

Em leitões infectados, a histologia revelou hiperemia moderada da parte distal do intestino delgado e ceco e camadas de bactérias agrupadas no epitélio intacto. Além disso, a adesão à mucosa ileal dos leitões apresenta o mesmo padrão encontrado nas células HEp-2. Esses achados sugerem que animais infectados pela EAggEC apresentam lesões distintas daquelas provocadas por outras categorias de E. coli (LAW; CHART, 1998; SAVARIANO et al., 1991).

A infecção pela EAggEC é diagnosticada através do isolamento da bactéria nas fezes dos pacientes e posterior ensaio que verifica o padrão de adesão agregativa em células Hep-2. Ensaios de PCR estão sendo desenvolvidos utilizando primers para identificar genes responsáveis por este padrão de adesão (LAW; CHART, 1998; NATARO; KAPER, 1998).

\section{E. coli DE ADERÊNCIA DIFUSA (DAEC)}

O termo $E$. coli de aderência difusa foi inicialmente utilizado para se referir a qualquer $E$. coli HEp-2 aderente que não formasse microcolônias típicas da EPEC. Com a descoberta da EAggEC, autores reconhecem a DAEC como uma categoria independente, potencial causadora 
de diarréia. Como se trata de uma categoria de E. coli ainda não muito estudada, pouco se sabe sobre sua patogênese (NATARO; KAPER, 1998; SERVIN, 2005).

Em Santiago, observou-se que o risco de diarréia pela DAEC aumenta da idade de 1 a 4-5 anos, porém a razão para este fenômeno idade-dependente não foi determinada. Seu diagnóstico é realizado pela observação do padrão de adesão difusa às células HEp-2 e não há nenhum ensaio de PCR para identificar tal estirpe (NATARO; KAPER, 1998).

\section{E. coli UROPATOGÊNICA (UPEC)}

As infecções do trato urinário são provavelmente a causa mais comum de infecção bacteriana em todo o mundo, e o principal agente etiológico é a $E$. coli uropatogênica. Em circunstâncias normais, essas bactérias são eliminadas, porém dependendo da suscetibilidade do hospedeiro e da virulência bacteriana, pode haver colonização do trato urinário (IWAHI et al., 1983; NAVEEN; MATHAI, 2005; TRABULSI et al., 2005).

No ano 2000, as infecções do trato urinário resultaram em 6,8 milhões de consultas médicas, 1,3 milhões de consultas de emergência e mais de 245000 hospitalizações de mulheres, com um custo anual de mais de 2,4 bilhões de dólares. Já nos homens, as infecções do trato urinário resultaram em 1,4 milhões de consultas médicas, 424 mil consultas emergenciais e 121 mil hospitalizações, com um custo de mais de um bilhão de dólares.(LANE et al., 2005).

No Brasil, $80 \%$ das consultas clínicas devem-se à infecção do trato urinário, que pode ocorrer pela via ascendente, hematógena ou linfática, sendo portanto o maior problema de saúde

pública. É também observada com freqüência em animais de companhia, como cães e gatos (YURI et al., 1998; KAU; HUNSTAD; HULTGREN, 2005; POLETTO; REIS, 2005;).

$\mathrm{Na}$ suinocultura, esta estirpe causa prejuízos devido a doenças puerperais, à redução do ganho de peso dos leitões e à taxa de mortalidade. Nos animais adultos, pode levar a anorexia, apatia, perda de peso, hipogalaxia, agalaxia, urina turva, prolapso de vagina, hematúria, polipnéia, taquicardia, hipertermia, cianose, ataxia, dificuldade para levantar-se e troca constante dos membros de apoio, e pode até causar a morte do animal (BRITO et al., 2004). 
Na necropsia de animais com nefrite, observa-se hemorragia renal com presença de pus, muco e sangue na região da pelve renal. Os ureteres apresentam-se dilatados e com filamentos de pus. Os animais com cistite apresentam a mucosa da bexiga inflamada e com muco espesso (BRITO et al., 2004).

Muitas linhagens de camundongos isogênicos têm sido utilizadas com sucesso como modelo para infecções do trato urinário, mas a suscetibilidade pode variar de acordo com a linhagem (HOPKINS, 1999).

Hopkins et al. (1998) examinaram a suscetibilidade, mecanismos de defesa e tempo para resolução de uma infecção do trato urinário provocada pela inoculação intravesical da E. coli em diferentes linhagens de camundongos, observando progressiva resolução da infecção nas linhagens isogênicas BALB/c, C3H/HeN, C57BL/6, DBA/1, DBA/2 e AKR. Porém, verificou-se também que as linhagens $\mathrm{C} 3 \mathrm{H} / \mathrm{HeJ}$ e $\mathrm{C} 3 \mathrm{H} / \mathrm{OuJ}$ demonstraram ser as mais susceptíveis, pois apresentaram níveis de infecções mais elevados, além de necessitarem de mais tempo para sua resolução.

Ao utilizar as linhagens C3H/HeN e C3H/HeJ , Justice e colaboradores, em 2004 observaram que após seis horas da inoculação da UPEC na bexiga desses camundongos e continuando por mais 32 horas, células polimorfonucleadas se dirigiam para as células infectadas apenas na primeira linhagem, fato não observado na $\mathrm{C} 3 \mathrm{H} / \mathrm{HeJ}$.

Este resultado provavelmente se deve ao fato de que $\mathrm{C} 3 \mathrm{H} / \mathrm{HeJ}$ apresenta uma mutação em tlr-4 (toll like receptor 4), que é importante para a resposta do hospedeiro a injuria epitelial. Esta mutação torna esta linhagem hiporesponsiva ao LPS ou bactérias Gram negativas. Porém, o comportamento de outras estirpes de UPEC e linhagens de camundongos ainda devem ser investigados (JUSTICE et al., 2004; FUKATA et al., 2005).

\section{Fatores de virulência}

As UPECs expressam muitos fatores de virulência, como as adesinas, toxinas, proteínas fixadoras de ferro (TRABULSI et al., 2005). 
As adesinas podem ser fimbriais, como a fímbria tipo 1 e fímbria $\mathrm{P}$, ou afimbriais. A fímbria P é codificada pelo operon pap e está presente em $20 \%$ das E coli fecais, $60 \%$ das causadoras de cistite e $80 \%$ das pielonefrites. Seu receptor é a globobiose, encontrada na membrana da célula epitelial (NAVEEN; MATHAI, 2005; TRABULSI et al., 2005).

A fímbria tipo 1 tem alta prevalência e provavelmente está envolvida na colonização do trato urinário baixo ao reconhecer proteínas na superfície luminal da bexiga humana e murina. Ela pode também ser considerada uma invasina, já que promove a invasão dessas células e deixa a UPEC endocitada protegida da ação de certos antibióticos e anticorpos (JUSTICE et al., 2004; NAVEEN; MATHAI, 2005; TRABULSI et al., 2005).

Ao escapar das defesas hospedeiras, uma subpopulação de UPEC é capaz de persistir por meses em modelos murinos, em um estado quiescente, que pode servir como uma "semente" para infecções recorrentes. Foi observado que camundongos com 500 a 1000 ufc de bactérias na bexiga servem como reservatórios para a UPEC e apresentam urina estéril. Já camundongos com níveis bacterianos mais altos $\left(10^{5}\right.$ a $\left.10^{7}\right)$ desenvolvem infecção aguda (SCHILLING; LORENZ; HULTGREN, 2002; JUSTICE et al., 2004).

O fator citotóxico necrosante (cnf) é considerado letal para os camundongos e cobaios, quando inoculado pelas vias intravenosa e intraperitoneal. Nas culturas de células Vero e HeLa, o fator citotóxico necrosante pode induzir uma reorganização do citoesqueleto, e levar a formação de células gigantes e multinucleadas (CAPRIOLI et al., 1983; JOHNSON, 1997).

A hemolisina é um dos principais fatores de virulência das UPECs. Ela promove uma vantagem seletiva a $E$. coli, pois forma poros na membrana dos enterócitos, e libera ferro para a bactéria (NAVEEN; MATHAI, 2005; TRABULSI et al., 2005).

\section{Patogênese}

As UPECs têm geralmente origem intestinal, mas podem migrar e colonizar regiões periuretrais. Oportunamente sobem até a bexiga, aderindo-se ao epitélio vesical através das fímbrias 1 e P (TRABULSI et al., 2005). 
Depois da adesão e invasão, em um modelo murino, observou-se que as UPECs são capazes de se replicar intracelularmente e formar coleções bacterianas, que podem levar a apoptose e esfoliação das células infectadas. A partir da bexiga, podem chegar aos rins, produzindo toxinas que lesam os glomérulos (JUSTICE et al., 2004; TRABULSI et al., 2005).

Kau, Hunstad e Hulgren, em 2005 observaram ainda que, em camundongos modelos para cistite, a invasão das células epiteliais pelas UPECs resultaram na formação de comunidades bacterianas intracelulares com crescimento e maturação semelhantes aos que ocorrem nos biofilmes. A bactéria adere-se de forma irreversível às superfícies, funcionando como um local de replicação e recrutamento de novas bactérias. Esta adesão dá origem a uma estrutura com formato de torre, característica do biofilme.

Durante a infecção, o tecido hospedeiro responde inicialmente com esfoliação do epitélio e influxo de neutrófilos. O epitélio da bexiga normalmente é renovado ao longo dos meses, porém em modelos murinos, após algumas horas do início da cistite essas cascatas de proliferação e diferenciação são ativadas (JUSTICE et al., 2004; KAU; HUNSTAD; HULTGREN, 2005).

\section{Diagnóstico}

Pode ser feito um exame microscópico da urina, sendo que a presença de 10 a 50 células brancas $/ \mathrm{mm}^{3}$ é considerado o limite normal. Além disso, deve-se fazer um exame microbiológico deste material (TRABULSI et al., 2005).

\section{Tratamento}

É recomendada a antibioticoterapia, após realização de antibiograma (TRABULSI et al., 2005). 
Ao inocular intravesicalmente a UPEC em camundongos C57BL/6 observou-se que $36 \%$ deles apresentaram pelo menos um episódio de recorrência, $21 \%$ mais de um episódio ao longo de seis semanas após a infecção aguda. O tratamento com trimetropim sulfametoxazol reduziu a recorrência e erradicou a colonização fecal, mas não foi capaz de erradicá-la da bexiga, demonstrando que reservatórios podem persistir mesmo após longa antibioticoterapia (SCHILLING; LORENZ; HULTGREN, 2002).

\section{Epidemiologia e prevenção}

As infecções do trato urinário atingem mais as fêmeas jovens. É o tipo mais comum de infecção hospitalar, em decorrência do uso de cateteres urinários (TRABULSI et al., 2005).

Em 2005, Poletto e Reis analisaram 442 amostras de urina e identificaram 78 delas como positivas para infecção do trato urinário. A E. coli foi o microrganismo prevalente $(67,9 \%)$ causador desta infecção.

Em animais, existem poucos relatos sobre fatores de virulência de E. coli urinárias, mas o resultado de análises de infecções causadas por este agente em cães e humanos sugerem que UPECs similares podem ser capazes de causar infecção em ambos (YURI et al., 1998).

A prevenção das bacteriúrias nos animais, envolve uma série de medidas de manejo, como estimular o consumo de água, desinfecções periódicas e uso de medicamentos estratégicos, como drogas antimicrobianas em doses sub terapêuticas (BRITO et al., 2004).

Uma outra medida profilática que tem mostrado bons resultados é o uso de probióticos, que restauram a flora normal e impedem a colonização por E. coli (TRABULSI et al., 2005). 


\section{OBJETIVOS}

O presente trabalho teve como objetivos:

- Analisar as microbiotas aeróbias bacteriana e fúngica presentes no intestino das linhagens de camundongos Swiss, C57BL/6, BALB/c, C3H/HePas, C3H/HeJ, MDX e YCx43, verificando se existem diferenças entre elas.

- Avaliar a suscetibilidade "in vitro" frente aos antimicrobianos das E. coli isoladas, verificando se existem diferenças entre as linhagens.

- Verificar a ocorrência de resistência a múltiplos antimicrobianos nas E. coli isoladas.

- Pesquisar os fatores de virulência das estirpes de E. coli isoladas, também investigando se existem diferenças destes entre as linhagens estudadas.

- Identificar os microrganismos presentes nos diferentes ambientes em que estes animais são mantidos, verificando se existem diferenças entre eles. 


\section{MATERIAIS E MÉTODO}

O estudo foi realizado utilizando-se as instalações do biotério e do Laboratório de Patologia Animal, ambos do Departamento de Patologia, e do Laboratório de Doenças Infecciosas (Bacteriologia e Micologia) do Departamento de Medicina Veterinária Preventiva e Saúde Animal, todos da Faculdade de Medicina Veterinária e Zootecnia da Universidade de São Paulo.

COLHEITA DO MATERIAL

Foram selecionados camundongos das linhagens Swiss, C57BL/6, BALB/c, C3H/HePas, C3H/HeJ, MDX e YCX43, de padrão sanitário monitorizado (ILAR NEWS, 1976), de diferentes idades e ambos os sexos, destinados ao descarte, sem nunca terem sido utilizados em qualquer experimento.

Este biotério é dotado de condicionamento de ar com temperatura de $22 \pm 2{ }^{\circ} \mathrm{C}$, umidade relativa do ar entre 45 e $60 \%$ e ventilação geral diluidora (VGD) com insuflação pelo teto e taxa de renovação de ar com 22 trocas por hora, e exaustão a um plano posterior às estantes, em 3 alturas (superior, média e inferior). As salas eram providas de timer marca $\mathrm{L} \& \mathrm{D} \otimes$, que proporcionava fotoperíodo de 12 horas de claro: 12 horas de escuro. Os animais recebiam ração Nuvilab CR-1® (Nuvital, Curitiba, PR) e água ad libitum.

Os camundongos foram eutanasiados em câmara de $\mathrm{CO}_{2}$ e posteriormente identificados e necropsiados em um fluxo laminar. Durante a necropsia, foi realizada uma incisão no ceco do animal, por onde foi colhida, utilizando-se uma alça bacteriológica estéril, pequena quantidade de suas fezes. Este material foi inoculado em caldo BHI (Brain Heart Infusion Broth), e incubado em estufa a $37^{\circ} \mathrm{C}$ durante uma hora (Figura 1). 


\section{ISOLAMENTO E IDENTIFICAÇÃO DOS MICRORGANISMOS PRESENTES NAS FEZES DOS ANIMAIS}

O caldo BHI foi semeado ágar sangue de carneiro (5\%), ágar MacConkey e ágar Saboraud dextrose, sendo os dois primeiros incubados em aerobiose a $37^{\circ} \mathrm{C}$ por 24 a 48 horas e o último em temperatura ambiente (aproximadamente $25^{\circ} \mathrm{C}$ ) e avaliado diariamente durante uma semana, verificando-se um possível crescimento de fungos. Após a semeadura nas placas, o caldo BHI também foi incubado em aerobiose a $37^{0} \mathrm{C}$ por 24 horas, período após o qual foi semeado em ágar sangue de carneiro (5\%) e ágar MacConkey, procedendo-se à incubação de forma similar à descrita anteriormente (Figura 1).

Os microrganismos isolados foram identificados de acordo com Lennette et al. (1985) e classificados segundo Kreeger-Van-Rig (1984), Krieg; Holt (1994) e Murray et al. (1999).

TESTES DE SUSCETIBILIDADE “IN VITRO” DAS ESTIRPES DE $E$. coli ISOLADAS DAS FEZES DOS ANIMAIS FRENTE A DIFERENTES ANTIMICROBIANOS E PESQUISA DE RESISTÊNCIA MÚLTIPLA E SEU ÍNDICE

Os testes se suscetibilidade "in vitro" das estirpes de E. coli isoladas foram realizados frente a diferentes antibióticos e quimioterápicos, a saber: cloranfenicol $(30 \mu \mathrm{g})$, tetraciclina $(30 \mu \mathrm{g})$, cefalotina $(30 \mu \mathrm{g})$, gentamicina $(10 \mu \mathrm{g})$, sulfa+trimetoprin $(25 \mu \mathrm{g})$, ampicilina $(10 \mu \mathrm{g})$, tobramicina $(10 \mu \mathrm{g})$, amoxicilina $(10 \mu \mathrm{g})$, cefoxitina $(30 \mu \mathrm{g})$, aztreonam $(30 \mu \mathrm{g})$, cefotaxima $(30 \mu \mathrm{g})$ e amicacina $(30 \mu \mathrm{g})$.

Os antibiogramas foram realizados em meio de Müller \& Hinton, empregando-se o método de disco difusão, segundo técnica de Bauer et al. (1966). Sua interpretação foi realizada pela medida do diâmetro do halo de inibição do crescimento do microrganismo. As concentrações, bem como o critério de interpretação, foram os recomendados pela "National Commitee for Clinical Laboratory Standards - NCCLS” (2001) (Figura 1). 
Foi também verificada a existência de resistência múltipla aos antimicrobianos, ou seja a resistência a três ou mais antimicrobianos na mesma estirpe de E. coli (MILES; McLAUGHLIN; BROWN, 2006; SAWANT et al., 2007). Já a pesquisa do índice de resistência múltipla (IRM) aos antimicrobianos foi realizada de acordo com Krumperman (1983), através do cálculo:

$\mathrm{IRM}=$ total de amostras resistentes $/\left(\mathrm{n}^{\mathrm{o}}\right.$ de antibióticos testados $\mathrm{x}$ tamanho da amostra)

\section{ESTUDO DA PRESENÇA DE FATORES DE VIRULÊNCIA EM ESTIRPES DE $E$. coli ISOLADAS DAS FEZES DOS ANIMAIS UTILIZANDO A REAÇÃO EM CADEIA DA POLIMERASE}

A pesquisa de fatores de virulência presentes nas estirpes de E.coli isoladas foi realizada através de reação em cadeia da polimerase (PCR). Foram utilizados os primers, comercialmente disponíveis, para detectar os genes que codificam os pili associados com pielonefrite (pap), aerobactina (iuc), fator citotóxico necrosante 1 ( $c n f l)$, fímbria S ( $f f a)$ e adesina afimbrial I ( $a f a)$, hemolisina ( $h l y)$, enterotoxina termo-lábil (LT), enterotoxina termo-estável ( $S T a$ e $S T b$ ), verotoxinas (VT1 e VT2). O tamanho dos amplicons e literatura relevantes são apresentados no quadro 1.

A extração do DNA foi realizada conforme descrito por Boom et al. (1990). A solução de amplificação padrão de PCR consistiu de $10 \mathrm{mM}$ Tris- $\mathrm{HCl}(\mathrm{pH} 8,3), 50 \mathrm{mM} \mathrm{KCl}, 1,5 \mathrm{mM}$ $\mathrm{MgCl}_{2}$, gelatina $0,001 \%, 200 \mu \mathrm{M}$ de cada um dos deoxinucleosídeos trifosfatos, seqüências de primers e $0,5 \mathrm{U}$ de Taq DNA polimerase, em um volume final de $25 \mu$ l. Os produtos amplificados foram separados em gel de agarose a 1,5\% e examinados eletroforeticamente após coloração com brometo de etídio. Foi utilizado um marcador de tamanho molecular de DNA de 100 bp (Figura $1)$. 


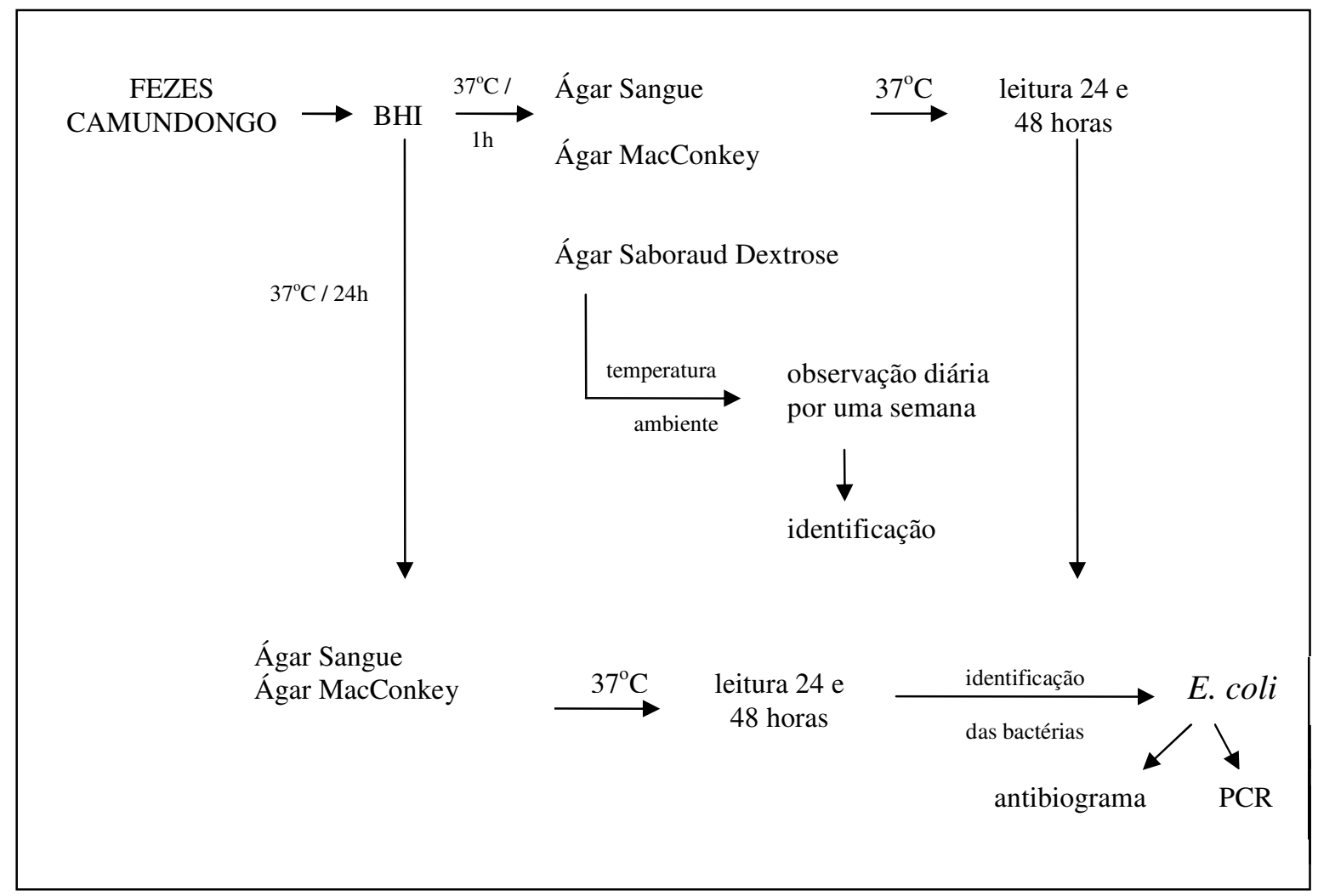

Figura 1 - Esquema do processamento das fezes coletadas de camundongos 


\begin{tabular}{|c|c|c|c|c|}
\hline Gene & Primer & Seqüência do oligonucleotídeo $\left(5^{\prime} \rightarrow 3^{\prime}\right)$ & $\begin{array}{c}\text { Tamanho } \\
\text { do produto } \\
\text { amplificado } \\
\text { (bp) }\end{array}$ & Referência \\
\hline \multirow{2}{*}{$\mathrm{LT}$} & LTA-1 & GGCGACAGATTATACCGTGC & \multirow{2}{*}{696} & \multirow{2}{*}{ SCHULTSZ et al., 1994} \\
\hline & LTA-2 & CCGAATTCTGTTATATATGTC & & \\
\hline \multirow{2}{*}{ STa } & STI-1 & TTAATAGCACCCGGTACAAGCAGG & \multirow{2}{*}{147} & \multirow{2}{*}{ OLSVIK et al., 1993} \\
\hline & STI-2 & CTTGACTCTTCAAAAGAGAAAATTAC & & \\
\hline \multirow{2}{*}{$\mathrm{STb}$} & STb-1 & ATCGCATTTCTTCTTGCATC & \multirow{2}{*}{172} & \multirow{2}{*}{ BLANCO et al., 1997} \\
\hline & STb-2 & GGGCGCCAAAGCATGCTCC & & \\
\hline \multirow{2}{*}{ VT1 } & VT1-A & GAAGAGTCCGTGGGATTACG & \multirow{2}{*}{130} & \multirow{2}{*}{ POLLARD et al., 1990} \\
\hline & VT1-B & AGCGATGCAGCTATTAATAA & & \\
\hline \multirow{2}{*}{ VT2 } & VT2-3 & CCGTCAGGACTGTCTGAAAC & \multirow{2}{*}{726} & \multirow{2}{*}{$\begin{array}{c}\text { WOODWARD et al., } \\
1992\end{array}$} \\
\hline & VT2-5 & GAGTCTGACAGGCAACTGTC & & \\
\hline \multirow{2}{*}{ pap } & pap-1 & GCAACAGCAACGCTGGTTGCATCAT & \multirow{2}{*}{336} & \multirow{2}{*}{ YAMAMOTO et al., 1995} \\
\hline & pap-2 & AGAGAGAGCCACTCTTATACGGACA & & \\
\hline \multirow{2}{*}{ hly } & $h l y-1$ & AACAAGGATAAGCACTGTTCTGGCT & \multirow{2}{*}{1177} & \multirow{2}{*}{ YAMAMOTO et al., 1995} \\
\hline & $h l y-2$ & ACCATATAAGCGGTCATTCCCGTCA & & \\
\hline \multirow{2}{*}{ iuc } & $i u c-1$ & TACCGGATTGTCATATGCAGACCGT & \multirow{2}{*}{602} & \multirow{2}{*}{ YAMAMOTO et al., 1995} \\
\hline & $i u c-2$ & АATATCTTCCTCCAGTCCGGAGAAG & & \\
\hline \multirow{2}{*}{ cnf } & cnf-1 & AAGATGGAGTTTCCTATGCAGGAG & \multirow{2}{*}{498} & \multirow{2}{*}{ YAMAMOTO et al., 1995} \\
\hline & $c n f-2$ & CATTCAGAGTCCTGCCCTCATTATT & & \\
\hline \multirow{2}{*}{$s f a$} & $s f a-1$ & CTCCGGAGAACTGGGTGCATCTTAC & \multirow{2}{*}{410} & \multirow{2}{*}{ YAMAMOTO et al., 1995} \\
\hline & $s f a-2$ & CGGAGGAGTAAATACAAACCTGGCA & & \\
\hline \multirow{2}{*}{$a f a$} & afa-1 & GCTGGGCAGCAAACTGATAACTCTC & \multirow{2}{*}{750} & \multirow{2}{*}{ YAMAMOTO et al., 1995} \\
\hline & $a f a-2$ & CATCAAGCTGTTTGTTCGTCCGCCG & & \\
\hline
\end{tabular}

Quadro 1 - Listagem de "primers" que foram utilizados na PCR para amplificar fragmentos de diferentes genes para enterotoxinas, verotoxinas e de diferentes genes para pap, hly, iuc, cnfl, sfa e afa

\section{ISOLAMENTO E IDENTIFICAÇÃO DOS MICRORGANISMOS PRESENTES NO AMBIENTE E LUVAS DOS MANIPULADORES}

Para a investigação dos microrganismos presentes no ambiente em que os animais são criados, foram abertas por 15 minutos, em cada sala de camundongos do biotério, placas de Petri 
contendo os meios ágar sangue, ágar MacConkey e ágar Saboraud Dextrose. Este procedimento foi realizado nos dias de troca de cama dos animais.

Os dois primeiros meios foram incubados em aerobiose a $37^{0} \mathrm{C}$ por 24 a 48 horas e o último em temperatura ambiente (aproximadamente $25^{\circ} \mathrm{C}$ ). Após este período, foi realizada a contagem das unidades formadoras de colônia e posterior identificação de acordo com Lennette et al. (1985) e classificados segundo Kreger-Van-Rij (1984), Krieg; Holt (1994) e Murray et al. (1999).

Foram realizados também suabes de locais do biotério como mesas e maçanetas de portas, sendo estes suabes semeados em caldo BHI, e seu processamento realizado da mesma maneira como descrita para os animais.

Para coletar as amostras das maçanetas das portas os suabes foram feitos por toda a sua extensão. Já para os suabes da mesa, foram determinadas regiões, confeccionando moldes de papel autoclavados com dimensões 10 X $10 \mathrm{~cm}$. A coleta foi realizada segundo Matsubara (2005) em cinco pontos diferentes da mesa, como ilustrado na figura 2 .
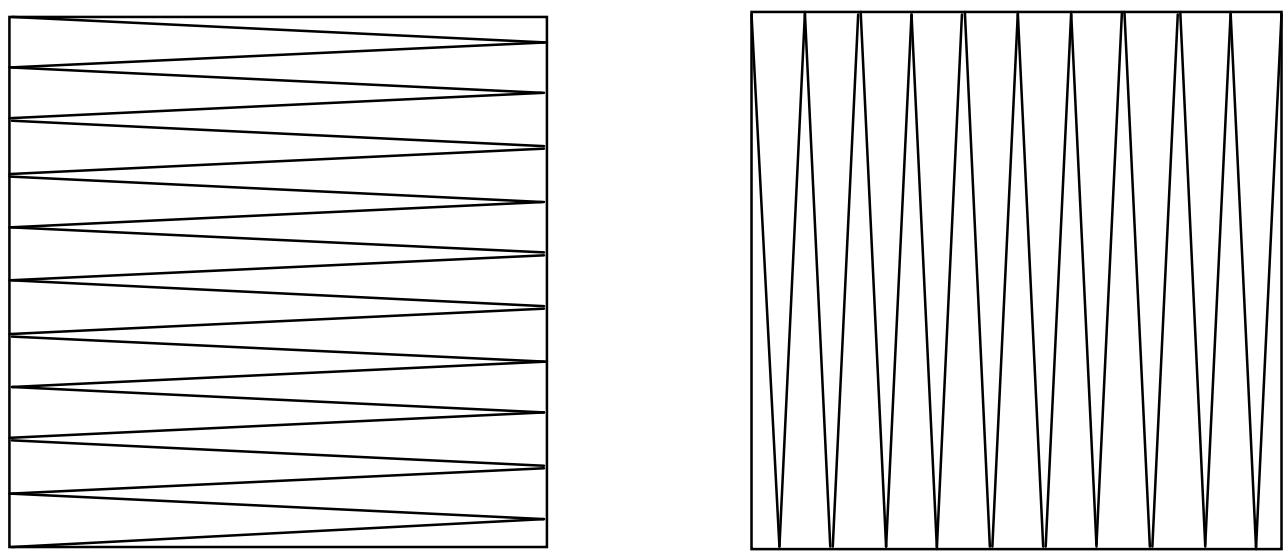

Figura 2 - Esquema da coleta das amostras de suabes realizados na mesa do biotério (MATSUBARA, 2005)

Além disso, para uma verificação ampla da presença de microrganismos em cada sala de camundongos do biotério, realizou-se suabes no exterior das luvas utilizadas pelos funcionários para a troca de maravalha dos animais. Nos dias de coleta era solicitado ao funcionário que 
utilizasse um par de luvas em cada sala e que este fosse depositado em uma placa de petri estéril ao final do trabalho. Como as luvas não eram estéreis, foram realizados também suabes de luvas limpas para verificar se apresentavam padrão microbiológico diferente das usadas, indicando quais bactérias realmente estariam presentes nas salas.

As linhagens estavam divididas da seguinte maneira: sala 1 (Swiss, C57BL/6 e $\mathrm{C} 3 \mathrm{H} / \mathrm{HePas}$ ), sala 2 (BALB/c, C3H/HeJ e MDX) e sala 3 (YCX43), tendo em média 12,30 metros quadrados, higienizadas pelo menos uma vez por semana. Os animais foram separados pela cor da pelagem (para evitar contaminação genética) e a linhagem geneticamente modificada fica em uma sala separada em obediência a normas de biossegurança.

\section{ANÁLISE ESTATÍSTICA}

Para a análise estatística dos resultados de freqüência de bactérias isoladas nas linhagens de camundongos foram realizados testes de análise de variância multivariada (MANOVA). Na análise dos resultados de antibiograma utilizou-se o teste exato de Fisher, análise de variância (ANOVA) e o teste t de Student. Já para analisar os dados obtidos no estudo microbiológico de luvas, mesas e portas do biotério utilizou-se novamente o teste de MANOVA. Todos os testes foram feitos com nível de significância de 5\%, utilizando-se o programa SAS (versão 8.02). 


\section{RESULTADOS}

\section{ISOLAMENTO E IDENTIFICAÇÃO DOS MICRORGANISMOS PRESENTES NAS FEZES DOS ANIMAIS}

Foram necropsiados 308 animais, sendo 45 da linhagem Swiss, 48 BALB/c, 46 C3H/HePas, 40 C3H/HeJ, 42 C57BL/6, 47 MDX e 40 camundongos da linhagem YCX43,

As bactérias mais freqüentemente isoladas foram E. coli (32\%), Staphylococcus spp (14\%), Bacillus spp (13\%), Streptococcus spp (9\%), Citrobacter amalonaticus (8\%) e Edwardsiella tarda biogrupo I (5\%) em diferentes freqüências entre as linhagens. Candida glabrata foi isolada apenas da linhagem MDX (10\%) (Tabela 1 e gráfico 1). 
Tabela 1 - Freqüência (n) e porcentagem (p) das bactérias isoladas nas linhagens de camundongos estudadas - São Paulo, agosto.2005 - dezembro. 2006

\begin{tabular}{|c|c|c|c|c|c|c|c|c|c|}
\hline & & Swiss & $\mathrm{BALB} / \mathrm{c}$ & $\mathrm{C} 3 \mathrm{H} / \mathrm{HePas}$ & $\mathrm{C} 3 \mathrm{H} / \mathrm{HeJ}$ & $\overline{\mathrm{C} 57 \mathrm{BL} / 6}$ & MDX & $\mathrm{YCx} 43$ & Total \\
\hline \multirow{2}{*}{ E.coli } & $\bar{n}$ & 27 & 38 & 28 & 26 & 24 & 44 & 32 & 219 \\
\hline & $\mathrm{p}$ & 60 & 79,2 & 60,9 & 65 & 57,1 & 93,6 & 80 & 32 \\
\hline \multirow{2}{*}{ Staphylococcus spp } & $\mathrm{n}$ & 7 & 26 & 16 & 23 & 1 & 10 & $\overline{15}$ & 98 \\
\hline & $\mathrm{p}$ & 15,6 & 54,2 & 34,8 & 57,5 & 2,4 & 21,3 & 37,5 & 14,3 \\
\hline \multirow{2}{*}{ Bacillus spp } & $\mathrm{n}$ & 14 & 18 & 18 & 11 & 18 & 9 & 2 & 90 \\
\hline & $\mathrm{p}$ & 31,1 & 37,5 & 39,1 & 27,5 & 42,9 & 19,1 & 5 & 13,2 \\
\hline \multirow{2}{*}{ Streptococcus spp } & $\mathrm{n}$ & 6 & 7 & 5 & 7 & 1 & 13 & 29 & 68 \\
\hline & $\mathrm{p}$ & 13,3 & 14,6 & 10,9 & 17,5 & 2,4 & 27,7 & 72,5 & 9,9 \\
\hline \multirow{2}{*}{ C. amalonaticus } & $\mathrm{n}$ & 13 & 10 & 14 & 4 & 12 & 1 & 2 & 56 \\
\hline & $\mathrm{p}$ & 28,9 & 20,8 & 30,4 & 10 & 28,6 & 2,1 & 5 & 8,2 \\
\hline \multirow{2}{*}{ Edw. tarda (biogrupo I) } & $\mathrm{n}$ & 8 & 0 & 8 & 2 & 17 & 0 & 2 & 37 \\
\hline & $\mathrm{p}$ & 17,8 & 0 & 17,4 & 5 & 40,5 & 0 & 5 & 5,4 \\
\hline \multirow{2}{*}{ Ser. marcencens } & $\mathrm{n}$ & 0 & 11 & 0 & 13 & 0 & 0 & 0 & 24 \\
\hline & $\mathrm{p}$ & 0 & 22,9 & 0 & 32,5 & 0 & 0 & 0 & 3,5 \\
\hline \multirow{2}{*}{ P. mirabillis } & $\mathrm{n}$ & 0 & 0 & 0 & 0 & 0 & 0 & 22 & 22 \\
\hline & $\mathrm{p}$ & 0 & 0 & 0 & 0 & 0 & 0 & 55 & 3,2 \\
\hline \multirow{2}{*}{ Ent. agglomerans } & $\mathrm{n}$ & 0 & 0 & 5 & 0 & 10 & 5 & 0 & 20 \\
\hline & $\mathrm{p}$ & 0 & 0 & 10,9 & 0 & 23,8 & 10,6 & 0 & 2,9 \\
\hline \multirow{2}{*}{ Enterococcus spp } & $\mathrm{n}$ & 0 & 0 & 1 & 0 & 2 & 7 & 0 & 10 \\
\hline & $\mathrm{p}$ & 0 & 0 & 2,2 & 0 & 4,8 & 14,9 & 0 & 1,5 \\
\hline \multirow{2}{*}{ Ser. liquefaciens } & $\mathrm{n}$ & 0 & 0 & 0 & 8 & 0 & 0 & 0 & 8 \\
\hline & $\mathrm{p}$ & 0 & 0 & 0 & 20 & 0 & 0 & 0 & 1,2 \\
\hline \multirow{2}{*}{$\begin{array}{l}\text { K. pneumoniae } \\
\text { subesp azanae }\end{array}$} & $\mathrm{n}$ & 0 & 0 & 1 & 4 & 0 & 1 & 0 & 6 \\
\hline & $\mathrm{p}$ & 0 & 0 & 2,2 & 10 & 0 & 2,1 & 0 & 0,9 \\
\hline \multirow{2}{*}{ C. diversus } & $\mathrm{n}$ & 1 & 0 & 0 & 2 & 0 & 2 & 0 & 5 \\
\hline & $\mathrm{p}$ & 2,2 & 0 & 0 & 5 & 0 & 4,3 & 0 & 0,7 \\
\hline \multirow{2}{*}{ K. oxytoca } & $\mathrm{n}$ & 1 & 0 & 0 & 0 & 0 & 1 & 2 & 4 \\
\hline & $\mathrm{p}$ & 2,2 & 0 & 0 & 0 & 0 & 2,1 & 5 & 0,6 \\
\hline \multirow{2}{*}{ Pse. aeruginosa } & $\mathrm{n}$ & 0 & 0 & 1 & 0 & 0 & 0 & 3 & 4 \\
\hline & $\mathrm{p}$ & 0 & 0 & 2,2 & 0 & 0 & 0 & 7,5 & 0,6 \\
\hline \multirow{2}{*}{$\begin{array}{c}\text { K. pneumoniae } \\
\text { subsp pneumoniae }\end{array}$} & $\mathrm{n}$ & $\overline{0}$ & 0 & 0 & 1 & $\overline{0}$ & $\overline{0}$ & 1 & 2 \\
\hline & $\mathrm{p}$ & 0 & 0 & 0 & 2,5 & 0 & 0 & 2,5 & 0,3 \\
\hline \multirow{2}{*}{ K. edwardsii } & $\mathrm{n}$ & 0 & 0 & 0 & 1 & 0 & 1 & 0 & 2 \\
\hline & $\mathrm{p}$ & 0 & 0 & 0 & 2,5 & 0 & 2,1 & 0 & 0,3 \\
\hline \multirow{2}{*}{ C. freundii } & $\mathrm{n}$ & 0 & 0 & 0 & 2 & 0 & 0 & 0 & 2 \\
\hline & $\mathrm{p}$ & 0 & 0 & 0 & 5 & 0 & 0 & 0 & 0,3 \\
\hline \multirow{2}{*}{ Ent. cloacae } & $\mathrm{n}$ & 0 & 1 & 0 & 1 & 0 & 0 & 0 & 2 \\
\hline & $\mathrm{p}$ & 0 & 2,1 & 0 & 2,5 & 0 & 0 & 0 & 0,3 \\
\hline \multirow{2}{*}{ P. vulgaris } & $\mathrm{n}$ & 0 & 0 & 0 & 0 & 0 & 0 & 1 & 1 \\
\hline & $\mathrm{p}$ & 0 & 0 & 0 & 0 & 0 & 0 & 2,5 & 0,1 \\
\hline Proteus snn & $\mathrm{n}$ & 0 & 0 & 0 & 0 & 0 & 0 & 1 & 1 \\
\hline Proteus spp & $\mathrm{p}$ & 0 & 0 & 0 & 0 & 0 & 0 & 2,5 & 0,1 \\
\hline Ser flexnerii & $\mathrm{n}$ & 0 & 0 & 0 & 0 & 0 & 1 & 0 & 1 \\
\hline & $\mathrm{p}$ & 0 & 0 & 0 & 0 & 0 & 2,1 & 0 & 0,1 \\
\hline Fut gerogenes & $\mathrm{n}$ & 0 & 0 & 0 & 0 & 0 & 1 & 0 & 1 \\
\hline & $\mathrm{p}$ & 0 & 0 & 0 & 0 & 0 & 2,1 & 0 & 0,1 \\
\hline$Y$ enterocolitica & $\mathrm{n}$ & 0 & 0 & 0 & 1 & 0 & 0 & 0 & 1 \\
\hline & $\mathrm{p}$ & 0 & 0 & 0 & 2,5 & 0 & 0 & 0 & 0,1 \\
\hline
\end{tabular}

$\mathrm{n}=$ número de amostras

$\mathrm{p}=$ porcentagem $(\mathrm{n} /$ número de animais por linhagem $\mathrm{x} 100)$

Edw $=$ Edwardsiella, Ser $=$ Serratia, Ent $=$ Enterobacter, Pse $=$ Pseudomonas 


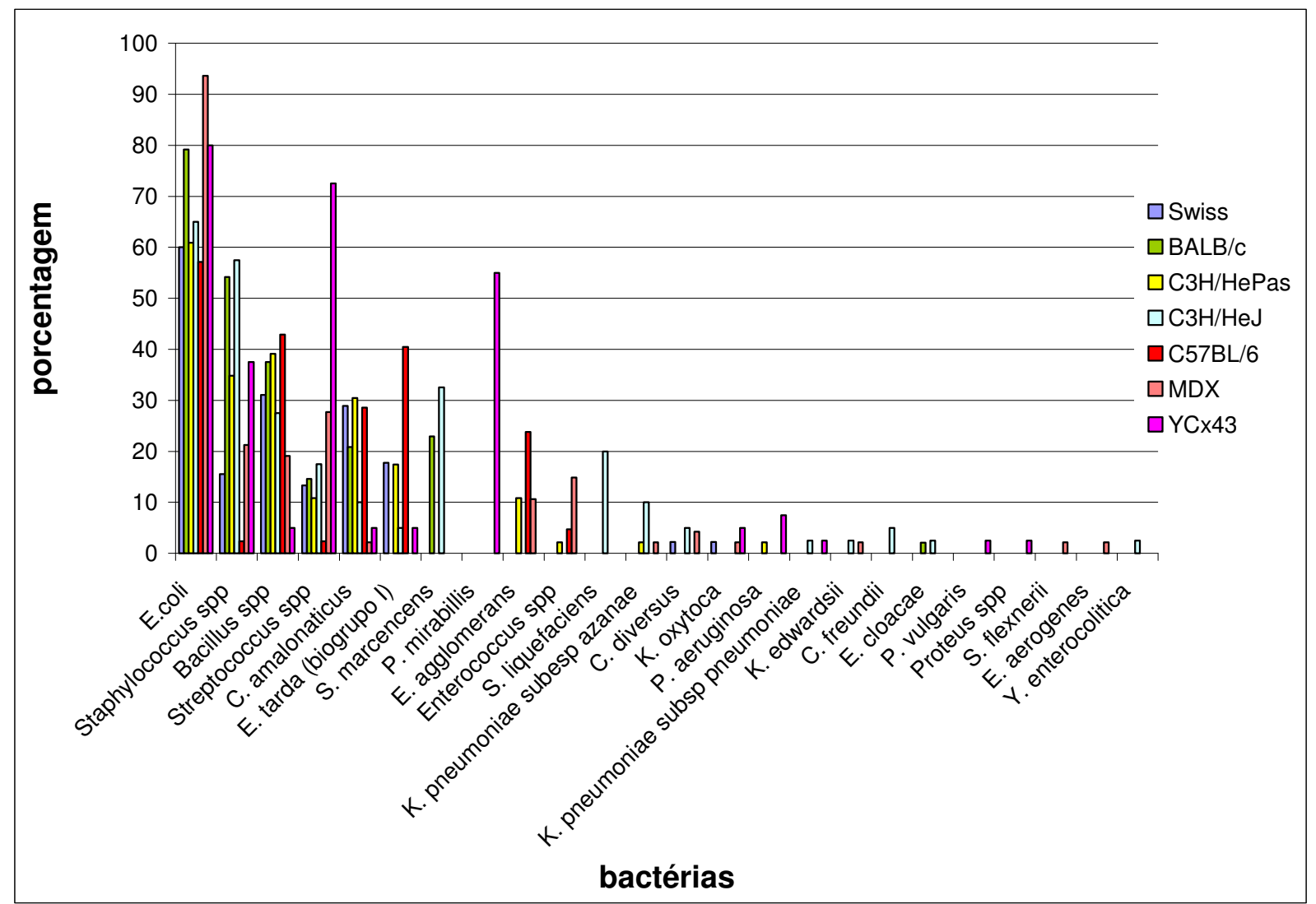

Gráfico 1 - Porcentagem das bactérias isoladas nas linhagens de camundongos estudadas

Foi realizado o teste de MANOVA, $\operatorname{com} \alpha=0,05$, para testar a hipótese de que a proporção de bactérias presentes no ceco de cada uma das linhagens é igual. Encontrou-se um p-valor igual a 0,0001, o que indica que as sete linhagens são diferentes com relação a sua microbiota.

Para que se soubesse com relação a quais bactérias as sete linhagens são diferentes, foi realizado um novo teste de MANOVA $(\alpha=0,05)$, que observou a freqüência relativa de cada bactéria em todas as linhagens (Tabela 2). 
Tabela 2 - P-valores encontrados no teste para avaliação da freqüência relativa de bactérias presentes no ceco das linhagens de camundongos estudadas

\begin{tabular}{|c|c|}
\hline Bactéria & P-valor \\
\hline E. coli & $0,0003^{*}$ \\
\hline Staphylococcus spp & $<0,0001 *$ \\
\hline Bacillus spp & $0,0013^{*}$ \\
\hline Streptococcus spp & $<0,0001 *$ \\
\hline C. amalonaticus & $0,0002 *$ \\
\hline $\begin{array}{l}E d w . \text { tarda } \\
\text { biogrupo I }\end{array}$ & $<0,0001 *$ \\
\hline Ser. marcencens & $<0,0001 *$ \\
\hline P. mirabillis & $<0,0001 *$ \\
\hline E. agglomerans & $<0,0001 *$ \\
\hline Enterococcus spp & $0,0001 *$ \\
\hline Ser. liquefaciens & $<, 0001 *$ \\
\hline $\begin{array}{l}\text { K. pneumoniae } \\
\text { subsp. azanae }\end{array}$ & $0,0083 *$ \\
\hline Pse. aeruginosa & $0,0178^{*}$ \\
\hline C. freundii & $0,0349 *$ \\
\hline C. diversus & 0,2476 \\
\hline K. oxytoca & 0,3977 \\
\hline $\begin{array}{l}\text { K. pneumoniae } \\
\text { subsp. pneumoniae }\end{array}$ & 0,4579 \\
\hline K. edwardsii & 0,5286 \\
\hline Ent. cloacae & 0,5374 \\
\hline P. vulgaris & 0,3509 \\
\hline Proteus spp & 0,3509 \\
\hline Ser.flexnerii & 0,4777 \\
\hline Ent. aerogenes & 0,4777 \\
\hline Y. enterocolitica & 0,3509 \\
\hline
\end{tabular}

Concluiu-se que não houve diferenças entre as linhagens quanto à freqüência relativa de ocorrência das bactérias Citrobacter diversus, Klebsiella oxytoca, K. pneumoniae subsp. 
pneumoniae, K. edwardsii, Enterobacter cloacae, Proteus vulgaris, Proteus spp, Shigella flexnerii, E. aerogenes e Yersinia enterocolitica.

Já para as bactérias E. coli, Staphylococcus spp, Bacillus spp, Streptococcus spp, C. amalonaticus, Edwardsiella tarda biogrupo I, Serratia marcencens, P. mirabillis, E. agglomerans, Enterococcus spp, S. liquefaciens, K. pneumoniae subsp azanae, Pseudomonas aeruginosa e $C$. freundii houve diferença estatisticamente significante entre as linhagens de camundongo.

A fim de pesquisar entre quais linhagens encontravam-se essas diferenças, um novo teste de MANOVA $(\alpha=0,05)$ foi realizado, comparando as linhagens duas a duas, para cada bactéria (Tabelas 3 e 4).

Tabela 3 - Comparação das linhagens de camundongos duas a duas para cada bactéria

\begin{tabular}{|c|c|c|c|c|c|c|c|c|c|c|}
\hline \multirow[b]{2}{*}{ Bactéria } & \multicolumn{10}{|c|}{ P-valores dos contrastes } \\
\hline & $\begin{array}{c}\text { Swiss X } \\
\text { C57BL/6 }\end{array}$ & $\begin{array}{l}\text { Swiss X } \\
\text { BALB/c }\end{array}$ & $\begin{array}{c}\text { Swiss X } \\
\text { C3H/HePas }\end{array}$ & $\begin{array}{c}\text { Swiss X } \\
\mathrm{C} 3 \mathrm{H} / \mathrm{HeJ}\end{array}$ & $\begin{array}{l}\text { Swiss X } \\
\text { MDX }\end{array}$ & $\begin{array}{l}\text { Swiss X } \\
\text { YCx43 }\end{array}$ & $\begin{array}{c}\text { C57BL/6 X } \\
\text { BALB/c }\end{array}$ & $\begin{array}{l}\text { C57BL/6 X } \\
\text { C3H/HePas }\end{array}$ & $\begin{array}{c}\text { C57BL/6 X } \\
\text { C3H/HeJ }\end{array}$ & $\begin{array}{c}\text { C57BL/6 } \\
\text { X MDX }\end{array}$ \\
\hline E. coli & 0,7623 & $0,0366^{*}$ & 0,925 & 0,6014 & $0,0003^{*}$ & $0,0373^{*}$ & $0,0185^{*}$ & 0,6917 & 0,4195 & $0,0001 *$ \\
\hline Staphylococcus ssp & 0,1565 & $<0,0001 *$ & $0,0347 *$ & $<0,0001 *$ & 0,5263 & $0,0202 *$ & $<0,0001^{*}$ & $0,0005^{*}$ & $<0,0001^{*}$ & $0,0404 *$ \\
\hline Bacillus spp & 0,2183 & 0,4884 & 0,3895 & 0,7084 & 0,1972 & $0,0072 *$ & 0,5682 & 0,6943 & 0,1183 & $0,0124 *$ \\
\hline Streptococcus spp & 0,1612 & 0,8685 & 0,7467 & 0,5982 & 0,0597 & $<0,0001 *$ & 0,1131 & 0,2747 & 0,0607 & $0,0012 *$ \\
\hline C. amalonaticus & 0,9684 & 0,2992 & 0,8436 & $0,0206^{*}$ & $0,0007 *$ & $0,0035^{*}$ & 0,3274 & 0,8152 & $0,0251 *$ & $0,001 *$ \\
\hline E. tarda biogrupo I & $0,0005^{*}$ & $0,0046^{*}$ & 0,9511 & 0,051 & $0,0048 *$ & 0,051 & $<0,0001^{*}$ & $0,0004 *$ & $<0,0001^{*}$ & $<0,0001^{*}$ \\
\hline S. marcencens & 1 & $<0,0001 *$ & 1 & $<0,0001 *$ & 1 & 1 & $<0,0001^{*}$ & 1 & $<0,0001^{*}$ & 1 \\
\hline P. mirabillis & 1 & 1 & 1 & 1 & 1 & $<0,0001^{*}$ & 1 & 1 & 1 & 1 \\
\hline E. agglomerans & $<0,0001^{*}$ & 1 & $0,0278 *$ & 1 & $0,0304^{*}$ & 1 & $<0,0001 *$ & $0,0102 *$ & $<0,0001^{*}$ & $0,0086^{*}$ \\
\hline Enterococcus spp & 0,1963 & 1 & 0,5456 & 1 & $<0,0001^{*}$ & 1 & 0,1895 & 0,4798 & 0,2095 & $0,0057 *$ \\
\hline S. liquefaciens & 1 & 1 & 1 & $<0,0001 *$ & 1 & 1 & 1 & 1 & $<0,0001^{*}$ & 1 \\
\hline $\begin{array}{l}\text { K. pneumoniae } \\
\text { subsp. azanae }\end{array}$ & 1 & 1 & 0,446 & $0,0008^{*}$ & 0,4534 & 1 & 1 & 0,454 & $0,001^{*}$ & 0,4614 \\
\hline P. aeruginosa & 1 & 1 & 0,3539 & 1 & 1 & $0,0022 *$ & 1 & 0,3624 & 1 & 1 \\
\hline C. freundii & 1 & 1 & 1 & $0,0041 *$ & 1 & 1 & 1 & 1 & $0,0047 *$ & 1 \\
\hline
\end{tabular}

* = valores significativos de $\mathrm{p}$

Edw $=$ Edwardsiella, Ser $=$ Serratia, Ent $=$ Enterobacter, Pse $=$ Pseudomonas 
Tabela 4 - Comparação das linhagens de camundongos duas a duas para cada bactéria (continuação)

\begin{tabular}{|c|c|c|c|c|c|c|c|c|c|c|c|}
\hline \multirow[b]{2}{*}{ Bactéria } & \multicolumn{11}{|c|}{ P-valores dos contrastes } \\
\hline & $\begin{array}{l}\text { C57BL/6 X } \\
\text { YCx43 }\end{array}$ & $\begin{array}{c}\mathrm{BALB} / \mathrm{c} \mathrm{X} \\
\mathrm{C} 3 \mathrm{H} / \mathrm{HePas}\end{array}$ & $\begin{array}{c}\mathrm{BALB} / \mathrm{c} \mathrm{X} \\
\mathrm{C} 3 \mathrm{H} / \mathrm{HeJ}\end{array}$ & $\begin{array}{l}\mathrm{BALB} / \mathrm{c} \\
\mathrm{X} \mathrm{MDX}\end{array}$ & $\begin{array}{c}\mathrm{BALB} / \mathrm{cX} \\
\mathrm{YCx} 43\end{array}$ & $\begin{array}{l}\mathrm{C} 3 \mathrm{H} / \mathrm{HePas} \\
\mathrm{X} \mathrm{C} 3 \mathrm{H} / \mathrm{HeJ}\end{array}$ & $\begin{array}{c}\mathrm{C} 3 \mathrm{H} / \mathrm{HePas} \\
\mathrm{X} \mathrm{MDX}\end{array}$ & $\begin{array}{c}\mathrm{C} 3 \mathrm{H} / \mathrm{HePas} \\
\mathrm{X} \mathrm{YCx} 43\end{array}$ & $\begin{array}{l}\mathrm{C} 3 \mathrm{H} / \mathrm{HeJ} \\
\mathrm{X} \mathrm{MDX}\end{array}$ & $\begin{array}{l}\mathrm{C} 3 \mathrm{H} / \mathrm{HeJ} \mathrm{X} \\
\mathrm{YCx} 43\end{array}$ & $\begin{array}{l}\text { MDX X } \\
\text { YCX43 }\end{array}$ \\
\hline E. coli & $0,0193 *$ & $0,0447 *$ & 0,1336 & 0,1105 & 0,9296 & 0,6644 & $0,0004^{*}$ & $0,0452 *$ & $0,0027 *$ & 0,1284 & 0,1513 \\
\hline $\begin{array}{l}\text { Staphylococcus } \\
\text { ssp }\end{array}$ & $0,0003^{*}$ & $0,0306^{*}$ & 0,719 & $0,0002 *$ & 0,0728 & $0,0157 *$ & 0,1331 & 0,7715 & $0,0001 *$ & $0,0394 *$ & 0,0821 \\
\hline Bacillus spp & $0,0001 *$ & 0,8588 & 0,2934 & $0,0448^{*}$ & $0,0007 *$ & 0,2264 & $0,0307 *$ & $0,0004 *$ & 0,3824 & $0,0241 *$ & 0,1394 \\
\hline Streptococcus spp & $<0,0001 *$ & 0,6208 & 0,7081 & 0,0806 & $<0,0001^{*}$ & 0,3995 & $0,0267^{*}$ & $<0,0001^{*}$ & 0,1948 & $<0,0001 *$ & $<0,0001^{*}$ \\
\hline C. amalonaticus & $0,0046^{*}$ & 0,2136 & 0,1763 & $0,0152 *$ & $0,0485^{*}$ & $0,0119^{*}$ & $0,0003^{*}$ & $0,0018^{*}$ & 0,3277 & 0,5496 & 0,7208 \\
\hline $\begin{array}{l}\text { E. tarda biogrupo } \\
\text { I }\end{array}$ & $<0,0001 *$ & $0,0053^{*}$ & 0,437 & 1 & 0,437 & 0,0571 & $0,0055^{*}$ & 0,0571 & 0,4392 & 1 & 0,4392 \\
\hline S. marcencens & 1 & $<0,0001 *$ & 0,0625 & $<0,0001 *$ & $<0,0001 *$ & $<0,0001^{*}$ & 1 & 1 & $<0,0001^{*}$ & $<0,0001 *$ & 1 \\
\hline P. mirabillis & $<0,0001^{*}$ & 1 & 1 & 1 & $<0,0001^{*}$ & 1 & 1 & $<0,0001^{*}$ & 1 & $<0,0001 *$ & $<0,0001^{*}$ \\
\hline E. agglomerans & $<0,0001 *$ & $0,0254 *$ & 1 & $0,0278^{*}$ & 1 & $0,0328^{*}$ & 0,9621 & $0,0328^{*}$ & $0,0357 *$ & 1 & $0,0357 *$ \\
\hline Enterococcus spp & 0,2095 & 0,5392 & 1 & $<0,0001^{*}$ & 1 & 0,5578 & $0,0004^{*}$ & 0,5578 & $<0,0001^{*}$ & 1 & $<0,0001 *$ \\
\hline S. liquefaciens & 1 & 1 & $<0,0001 *$ & 1 & 1 & $<0,0001 *$ & 1 & 1 & $<0,0001 *$ & $<0,0001 *$ & 1 \\
\hline $\begin{array}{l}\text { K. pneumoniae } \\
\text { subsp. azanae }\end{array}$ & 1 & 0,4387 & $0,0007 *$ & 0,446 & 1 & $0,0081^{*}$ & 0,9869 & 0,4598 & $0,0075^{*}$ & $0,0011^{*}$ & 0,4672 \\
\hline P. aeruginosa & $0,0026^{*}$ & 0,3462 & 1 & 1 & $0,0019 *$ & 0,3686 & 0,3487 & $0,0281 *$ & 1 & $0,0029 *$ & $0,002 *$ \\
\hline C. freundii & 1 & 1 & $0,0035^{*}$ & 1 & 1 & $0,0039^{*}$ & 1 & 1 & $0,0037 *$ & $0,0052 *$ & 1 \\
\hline
\end{tabular}

$*$ = valores significativos de $\mathrm{p}$

$E d w=$ Edwardsiella, Ser $=$ Serratia, Ent $=$ Enterobacter, Pse $=$ Pseudomonas

A bactéria $E$. coli apresentou freqüências relativas diferentes estatisticamente significantes nas comparações da linhagem Swiss, que foi menor que a BALB/c, MDX e YCX43; da C57BL/6, menor que a BALB/c, MDX e YCX43; da C3H/HePas, também menor que a BALB/c, MDX e YCX43; e da C3H/HeJ com menor freqüência relativa que a MDX.

Para Staphylococcus spp, foram observadas diferenças estatisticamente significantes de frequiência relativa nas linhagens Swiss, que foi menor que nas linhagens BALB/c, C3H/HePas, $\mathrm{C} 3 \mathrm{H} / \mathrm{HeJ}$ e YCX43; na C57BL/6, que também foi menor que a BALB/c, C3H/HePas, C3H/HeJ, MDX e YCX43; a BALB/c, com freqüência relativa da bactéria maior que a C3H/HePas e MDX; e na $\mathrm{C} 3 \mathrm{H} / \mathrm{HeJ}$, também maior que a C3H/HePas, MDX e YCX43. 
Já na pesquisa do Bacillus spp, encontraram-se diferenças estatisticamente significantes de freqüência relativa ente a linhagem Swiss que foi maior que a YCX43; a C57BL/6 maior que a MDX e YCX43; a BALB/c também foi maior que a MDX e YCX43; a C3H/HePas maior que a MDX e YCX43; e a C3H/HeJ também maior que a YCX43.

O Streptococcus spp apresentou freqüência relativa diferente estatisticamente significante nas comparações da linhagem Swiss, menor que a YCX43; a C57BL/6, também menor que a MDX e YCX43; a BALB/c, menor que a YCX43; a C3H/HePas também menor que a MDX e YCX43; e a YCX43 maior que a C3H/HeJ e MDX.

No estudo do $C$. amalonaticus, as diferenças estatisticamente significantes foram observadas nas comparações da linhagem Swiss, que foi maior que a C3H/HeJ, MDX e YCX43, a C57BL/6, também maior que a C3H/HeJ, MDX e YCX43; a BALB/c, maior que MDX e YCX43; e a $\mathrm{C} 3 \mathrm{H} / \mathrm{HePas}$ também com freqüência maior que a C3H/HeJ, MDX e YCX43.

A bactéria E. tarda biogrupo I foi isolada com freqüência relativa estatisticamente diferente nas comparações da linhagem Swiss, que foi menor que a C57BL/6 e maior que a BALB/c e MDX; a C57BL/6, maior que a BALB/c, C3H/HePas, C3H/HeJ, MDX e YCX43; e a C3H/HePas maior que BALB/c e MDX.

Já a pesquisa da bactéria $S$. marcencens apresentou diferenças na freqüência relativa estatisticamente significante nas linhagens Swiss, menor que a BALB/c e C3H/HeJ; a C57BL/6, menor que $\mathrm{BALB} / \mathrm{c}$ e $\mathrm{C} 3 \mathrm{H} / \mathrm{HeJ}$; a BALB/c, maior que a $\mathrm{C} 3 \mathrm{H} / \mathrm{HePas}$, MDX e $\mathrm{YCX} 43$; a $\mathrm{C} 3 \mathrm{H} / \mathrm{HeJ}$, também maior que C3H/HePas, MDX e YCX43.

Esses resultados estão ilustrados na figura 3, sendo que as linhas pontilhadas indicam comparações sem diferença estatística significante e as setas indicam comparações com diferença estatística significante, apontando para a linhagem com maior freqüência da bactéria em questão. 
E. coli

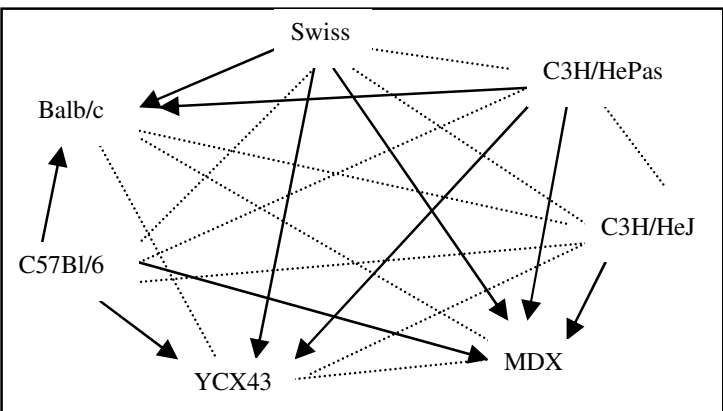

Bacillus spp

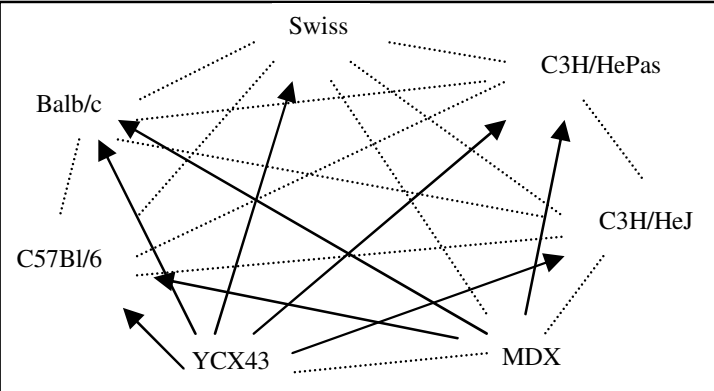

C. amalonaticus

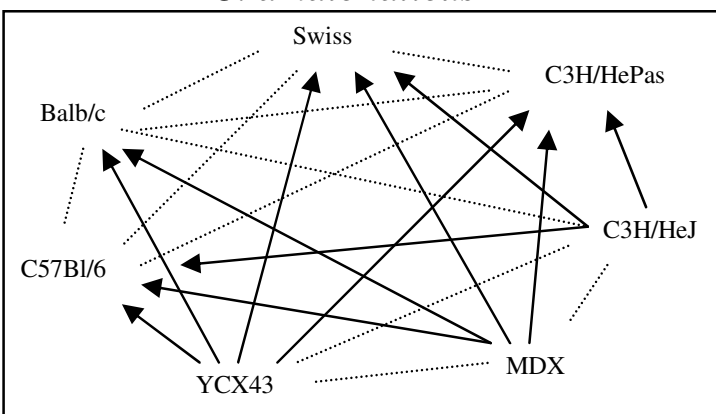

Staphylococcus spp

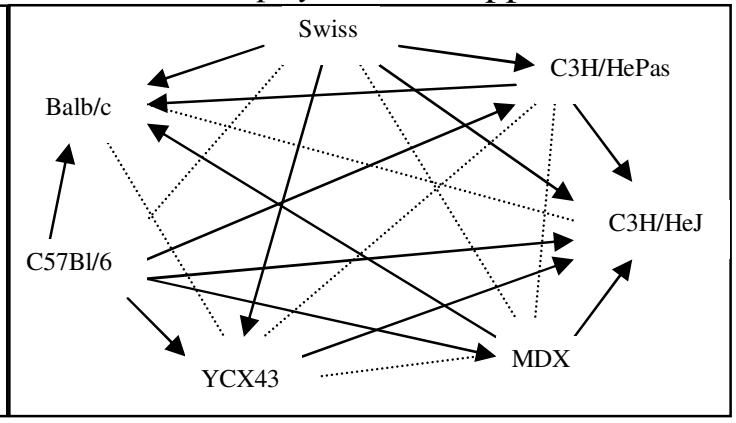

Streptococcus spp

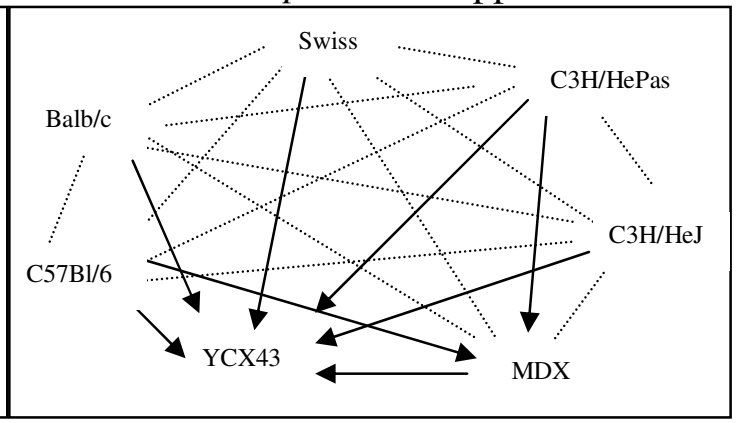

E. tarda biogrupo I

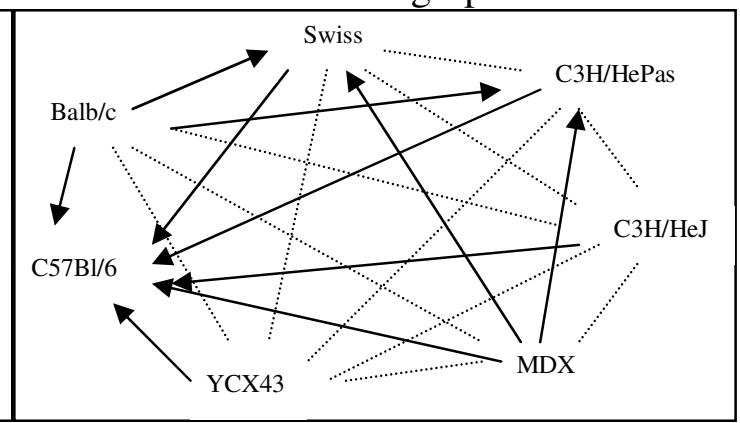

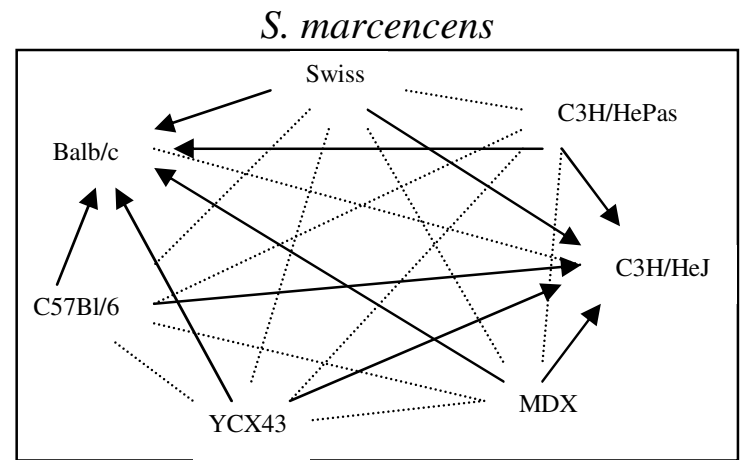

Figura 3 - Ilustração das comparações entre as frequiências relativas de bactérias encontradas nas linhagens de camundongos estudadas

As linhas pontilhadas indicam comparações sem diferença estatística significante e as setas indicam comparações com diferença estatística significante 
TESTES DE SUSCETIBILIDADE “IN VITRO” DAS ESTIRPES DE E. coli ISOLADAS DAS FEZES DOS ANIMAIS FRENTE A DIFERENTES ANTIMICROBIANOS

Foram realizados 219 antibiogramas das E. coli, sendo que para cada antibiótico, a amostra foi classificada como "resistente", "intermediária" ou "sensível", observando-se os resultados das tabelas 5, 6, 7 e gráficos 2, 3, 4 .

Tabela 5 - Freqüência (n) e porcentagem (p) das E. coli resistentes aos antimicrobianos testados, nas linhagens de camundongos - São Paulo, agosto.2005 - dezembro. 2006

\begin{tabular}{|c|c|c|c|c|c|c|c|c|c|}
\hline & & Swiss & BALB/c & $\mathrm{C} 3 \mathrm{H} / \mathrm{HePas}$ & $\mathrm{C} 3 \mathrm{H} / \mathrm{HeJ}$ & C57BL/6 & MDX & YCX43 & Total \\
\hline \multirow{2}{*}{ Amoxicilina } & $\mathrm{n}$ & 26 & 38 & 28 & 26 & 24 & 44 & 32 & 218 \\
\hline & $p$ & 96,3 & 100,0 & 100,0 & 100,0 & 100,0 & 100,0 & 100,0 & 99,5 \\
\hline \multirow{2}{*}{ Aztreonam } & $n$ & 1 & 1 & 0 & 0 & 1 & 1 & 0 & 4 \\
\hline & $p$ & 3,7 & 2,6 & 0,0 & 0,0 & 4,2 & 2,3 & 0,0 & 1,8 \\
\hline \multirow{2}{*}{ Cloranfenicol } & $n$ & 0 & 1 & 0 & 0 & 0 & 0 & 0 & 1 \\
\hline & $p$ & 0,0 & 2,6 & 0,0 & 0,0 & 0,0 & 0,0 & 0,0 & 0,5 \\
\hline \multirow{2}{*}{ Tetraciclina } & $n$ & 2 & 5 & 1 & 1 & 0 & 1 & 0 & 10 \\
\hline & $p$ & 7,4 & 13,2 & 3,6 & 3,8 & 0,0 & 2,3 & 0,0 & 4,6 \\
\hline \multirow{2}{*}{ Amicacina } & $\mathrm{n}$ & 5 & 13 & 12 & 4 & 7 & 18 & 2 & 61 \\
\hline & $p$ & 18,5 & 34,2 & 42,9 & 15,4 & 29,2 & 40,9 & 6,3 & 27,9 \\
\hline \multirow{2}{*}{ Gentamicina } & $n$ & 11 & 23 & 16 & 5 & 17 & 35 & 2 & 109 \\
\hline & $p$ & 40,7 & 60,5 & 57,1 & 19,2 & 70,8 & 79,5 & 6,3 & 49,8 \\
\hline \multirow{2}{*}{ Ampicilina } & $\mathrm{n}$ & 11 & 20 & 14 & 12 & 12 & 22 & 5 & 96 \\
\hline & $\mathrm{p}$ & 40,7 & 52,6 & 50,0 & 46,2 & 50,0 & 50,0 & 15,6 & 43,8 \\
\hline \multirow{2}{*}{ Tobramicina } & $\mathrm{n}$ & 5 & 12 & 16 & 7 & 12 & 34 & 5 & 91 \\
\hline & $\mathrm{p}$ & 18,5 & 31,6 & 57,1 & 26,9 & 50,0 & 77,3 & 15,6 & 41,6 \\
\hline \multirow{2}{*}{ Cefotaxima } & $n$ & 0 & 3 & 0 & 0 & 0 & 0 & 0 & 3 \\
\hline & $\mathrm{p}$ & 0,0 & 7,9 & 0,0 & 0,0 & 0,0 & 0,0 & 0,0 & 1,4 \\
\hline \multirow{2}{*}{$\begin{array}{c}\text { Sulfa }+ \\
\text { Trimetoprim }\end{array}$} & $\mathrm{n}$ & 0 & 0 & 0 & 0 & 2 & 2 & 0 & 4 \\
\hline & $\mathrm{p}$ & 0,0 & 0,0 & 0,0 & 0,0 & 8,3 & 4,5 & 0,0 & 1,8 \\
\hline \multirow{2}{*}{ Cefoxitina } & $\mathrm{n}$ & 1 & 5 & 1 & 0 & 2 & 1 & 1 & 11 \\
\hline & $\mathrm{p}$ & 3,7 & 13,2 & 3,6 & 0,0 & 8,3 & 2,3 & 3,1 & 5,0 \\
\hline \multirow{2}{*}{ Cefalotina } & $\mathrm{n}$ & 27 & 37 & 19 & 26 & 22 & 34 & 26 & 191 \\
\hline & $\mathrm{p}$ & 100,0 & 97,4 & 67,9 & 100,0 & 91,7 & 77,3 & 81,3 & 87,2 \\
\hline
\end{tabular}




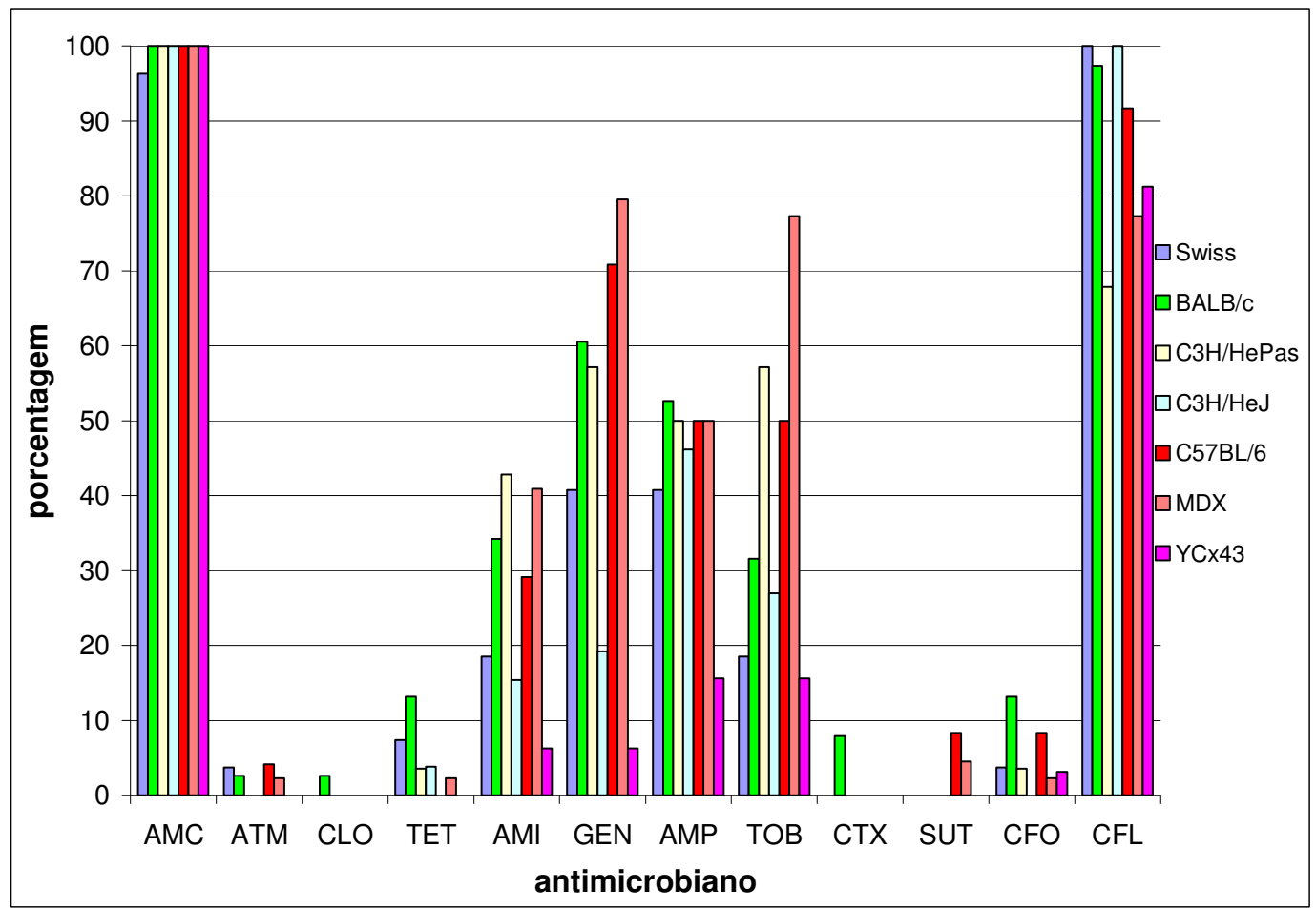

$\mathrm{AMC}=$ amoxicilina, $\mathrm{ATM}=$ aztreonam, $\mathrm{CLO}=$ cloranfenicol, $\mathrm{TET}=$ tetraciclina, $\mathrm{AMI}=$ amicacina, GEN = gentamicina, $\mathrm{AMP}=$ ampicilina, $\mathrm{TOB}=$ tobramicina, $\mathrm{CTX}=$ cefotaxima, $\mathrm{SUT}=$ sulfa+trimetoprin, $\mathrm{CFO}=$ cefoxitina e $\mathrm{CFL}=$ cefalotina.

Gráfico 2 - Porcentagem das E. coli resistentes aos antimicrobianos testados nas linhagens de camundongos 
Tabela 6 - Frequiência (n) e porcentagem (p) das E. coli intermediárias aos antimicrobianos testados nas linhagens de camundongos - São Paulo, agosto.2005 - dezembro. 2006

Swiss $\mathrm{BALB} / \mathrm{c} \quad \mathrm{C} 3 \mathrm{H} / \mathrm{HePas} \mathrm{C} 3 \mathrm{H} / \mathrm{HeJ}$ C57BL/6 $\mathrm{MDX}$ YCX43 Total

\begin{tabular}{|c|c|c|c|c|c|c|c|c|c|}
\hline \multirow{2}{*}{ Amoxicilina } & $\mathrm{n}$ & 0 & 0 & 0 & 0 & 0 & 0 & 0 & 0 \\
\hline & $p$ & 0,0 & 0,0 & 0,0 & 0,0 & 0,0 & 0,0 & 0,0 & 0,0 \\
\hline \multirow{2}{*}{ Aztreonam } & $\mathrm{n}$ & 9 & 23 & 2 & 5 & 7 & 5 & 9 & 60 \\
\hline & $p$ & 33,3 & 60,5 & 7,1 & 19,2 & 29,2 & 11,4 & 28,1 & 27,4 \\
\hline \multirow{2}{*}{ Cloranfenicol } & $\mathrm{n}$ & 0 & 0 & 0 & 0 & 0 & 0 & 0 & 0 \\
\hline & $p$ & 0,0 & 0,0 & 0,0 & 0,0 & 0,0 & 0,0 & 0,0 & 0,0 \\
\hline \multirow{2}{*}{ Tetraciclina } & $\mathrm{n}$ & 11 & 15 & 3 & 16 & 5 & 6 & 11 & 67 \\
\hline & $p$ & 40,7 & 39,5 & 10,7 & 61,5 & 20,8 & 13,6 & 34,4 & 30,6 \\
\hline \multirow{2}{*}{ Amicacina } & $\mathrm{n}$ & 6 & 2 & 3 & 8 & 5 & 3 & 5 & 32 \\
\hline & $p$ & 22,2 & 5,3 & 10,7 & 30,8 & 20,8 & 6,8 & 15,6 & 14,6 \\
\hline \multirow{2}{*}{ Gentamicina } & $\mathrm{n}$ & 9 & 8 & 1 & 6 & 6 & 0 & 9 & 39 \\
\hline & $p$ & 33,3 & 21,1 & 3,6 & 23,1 & 25,0 & 0,0 & 28,1 & 17,8 \\
\hline \multirow{2}{*}{ Ampicilina } & $\mathrm{n}$ & 12 & 13 & 7 & 12 & 7 & 12 & 16 & 79 \\
\hline & $p$ & 44,4 & 34,2 & 25,0 & 46,2 & 29,2 & 27,3 & 50,0 & 36,1 \\
\hline \multirow{2}{*}{ Tobramicina } & $n$ & 11 & 17 & 0 & 8 & 12 & 0 & 17 & 65 \\
\hline & $p$ & 40,7 & 44,7 & 0,0 & 30,8 & 50,0 & 0,0 & 53,1 & 29,7 \\
\hline \multirow{2}{*}{ Cefotaxima } & $n$ & 10 & 12 & 2 & 8 & 8 & 2 & 10 & 52 \\
\hline & $p$ & 37,0 & 31,6 & 7,1 & 30,8 & 33,3 & 4,5 & 31,3 & 23,7 \\
\hline \multirow{2}{*}{$\begin{array}{c}\text { Sulfa }+ \\
\text { Trimetoprim }\end{array}$} & $n$ & 0 & 1 & 0 & 0 & 1 & 9 & 0 & 11 \\
\hline & $p$ & 0,0 & 2,6 & 0,0 & 0,0 & 4,2 & 20,5 & 0,0 & 5,0 \\
\hline \multirow{2}{*}{ Cefoxitina } & $\mathrm{n}$ & 1 & 7 & 1 & 3 & 3 & 6 & 1 & 22 \\
\hline & $p$ & 3,7 & 18,4 & 3,6 & 11,5 & 12,5 & 13,6 & 3,1 & 10,0 \\
\hline \multirow{2}{*}{ Cefalotina } & $\mathrm{n}$ & 0 & 0 & 2 & 0 & 0 & 4 & 2 & 8 \\
\hline & $p$ & 0,0 & 0,0 & 7,1 & 0,0 & 0,0 & 9,1 & 6,3 & 3,7 \\
\hline
\end{tabular}




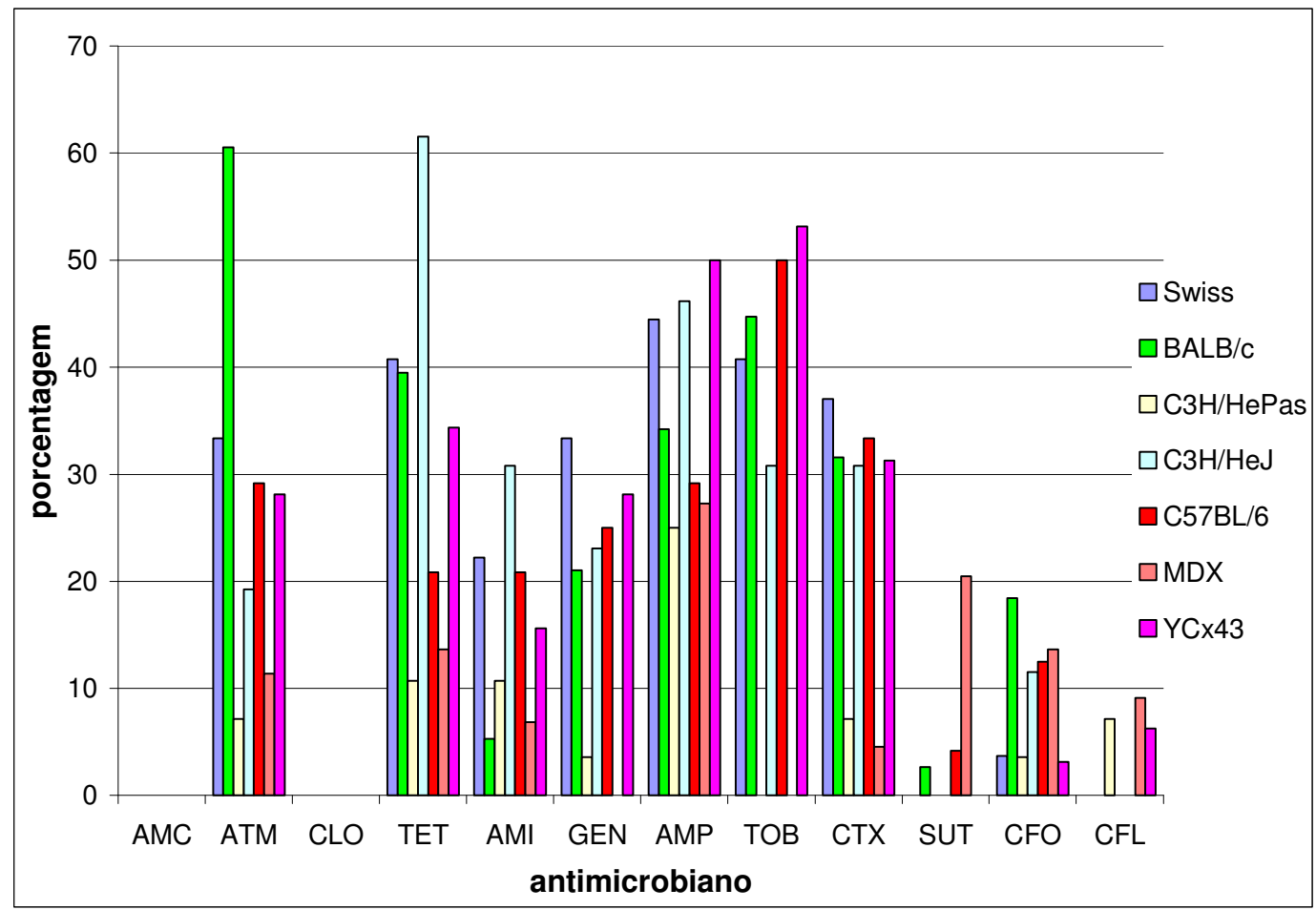

$\mathrm{AMC}=$ amoxicilina, $\mathrm{ATM}=$ aztreonam, $\mathrm{CLO}=$ cloranfenicol, $\mathrm{TET}=$ tetraciclina, $\mathrm{AMI}=$ amicacina, $\mathrm{GEN}=$ gentamicina, $\mathrm{AMP}=$ ampicilina, $\mathrm{TOB}=$ tobramicina, $\mathrm{CTX}=$ cefotaxima, $\mathrm{SUT}=$ sulfa+trimetoprin, $\mathrm{CFO}=$ cefoxitina e $\mathrm{CFL}=$ cefalotina.

Gráfico 3 - Porcentagem das E. coli intermediárias aos antimicrobianos testados nas linhagens de camundongos 
Tabela 7 - Frequiência (n) e porcentagem (p) das E. coli sensíveis aos antimicrobianos testados nas linhagens de camundongos - São Paulo, agosto.2005 - dezembro. 2006

\begin{tabular}{|c|c|c|c|c|c|c|c|c|c|}
\hline & & Swiss & BALB/C & $\mathrm{C} 3 \mathrm{H} / \mathrm{HePas}$ & $\mathrm{C} 3 \mathrm{H} / \mathrm{HeJ}$ & C57BL/6 & MDX & YCX43 & Total \\
\hline \multirow{2}{*}{ Amoxicilina } & $\mathrm{n}$ & 1 & 0 & 0 & 0 & 0 & 0 & 0 & 1 \\
\hline & $\mathrm{p}$ & 3,7 & 0,0 & 0,0 & 0,0 & 0,0 & 0,0 & 0,0 & 0,5 \\
\hline \multirow{2}{*}{ Aztreonam } & $n$ & 17 & 14 & 26 & 21 & 16 & 38 & 23 & 155 \\
\hline & $p$ & 63,0 & 36,8 & 92,9 & 80,8 & 66,7 & 86,4 & 71,9 & 70,8 \\
\hline \multirow{2}{*}{ Cloranfenicol } & $\mathrm{n}$ & 27 & 37 & 28 & 26 & 24 & 44 & 32 & 218 \\
\hline & $\mathrm{p}$ & 100,0 & 97,4 & 100,0 & 100,0 & 100,0 & 100,0 & 100,0 & 99,5 \\
\hline \multirow{2}{*}{ Tetraciclina } & $\mathrm{n}$ & 14 & 18 & 24 & 9 & 19 & 37 & 21 & 142 \\
\hline & $\mathrm{p}$ & 51,9 & 47,4 & 85,7 & 34,6 & 79,2 & 84,1 & 65,6 & 64,8 \\
\hline \multirow{2}{*}{ Amicacina } & $n$ & 16 & 23 & 13 & 14 & 12 & 23 & 25 & 126 \\
\hline & $p$ & 59,3 & 60,5 & 46,4 & 53,8 & 50,0 & 52,3 & 78,1 & 57,5 \\
\hline \multirow{2}{*}{ Gentamicina } & $n$ & 7 & 7 & 11 & 15 & 1 & 9 & 21 & 71 \\
\hline & $p$ & 25,9 & 18,4 & 39,3 & 57,7 & 4,2 & 20,5 & 65,6 & 32,4 \\
\hline \multirow{2}{*}{ Ampicilina } & $n$ & 4 & 5 & 7 & 2 & 5 & 10 & 11 & 44 \\
\hline & $p$ & 14,8 & 13,2 & 25,0 & 7,7 & 20,8 & 22,7 & 34,4 & 20,1 \\
\hline \multirow{2}{*}{ Tobramicina } & $\mathrm{n}$ & 11 & 9 & 12 & 11 & 0 & 10 & 10 & 63 \\
\hline & $p$ & 40,7 & 23,7 & 42,9 & 42,3 & 0,0 & 22,7 & 31,3 & 28,8 \\
\hline \multirow{2}{*}{ Cefotaxima } & $n$ & 17 & 23 & 26 & 18 & 16 & 42 & 22 & 164 \\
\hline & $\mathrm{p}$ & 63,0 & 60,5 & 92,9 & 69,2 & 66,7 & 95,5 & 68,8 & 74,9 \\
\hline \multirow{2}{*}{$\begin{array}{c}\text { Sulfa + } \\
\text { Trimetoprim }\end{array}$} & $\mathrm{n}$ & 27 & 37 & 28 & 26 & 21 & 33 & 32 & 204 \\
\hline & $\mathrm{p}$ & 100,0 & 97,4 & 100,0 & 100,0 & 87,5 & 75,0 & 100,0 & 93,2 \\
\hline \multirow{2}{*}{ Cefoxitina } & $n$ & 25 & 26 & 26 & 23 & 19 & 37 & 30 & 186 \\
\hline & $p$ & 92,6 & 68,4 & 92,9 & 88,5 & 79,2 & 84,1 & 93,8 & 84,9 \\
\hline \multirow{2}{*}{ Cefalotina } & $\mathrm{n}$ & 0 & 1 & 7 & 0 & 2 & 6 & 4 & 20 \\
\hline & $p$ & 0,0 & 2,6 & 25,0 & 0,0 & 8,3 & 13,6 & 12,5 & 9,1 \\
\hline
\end{tabular}




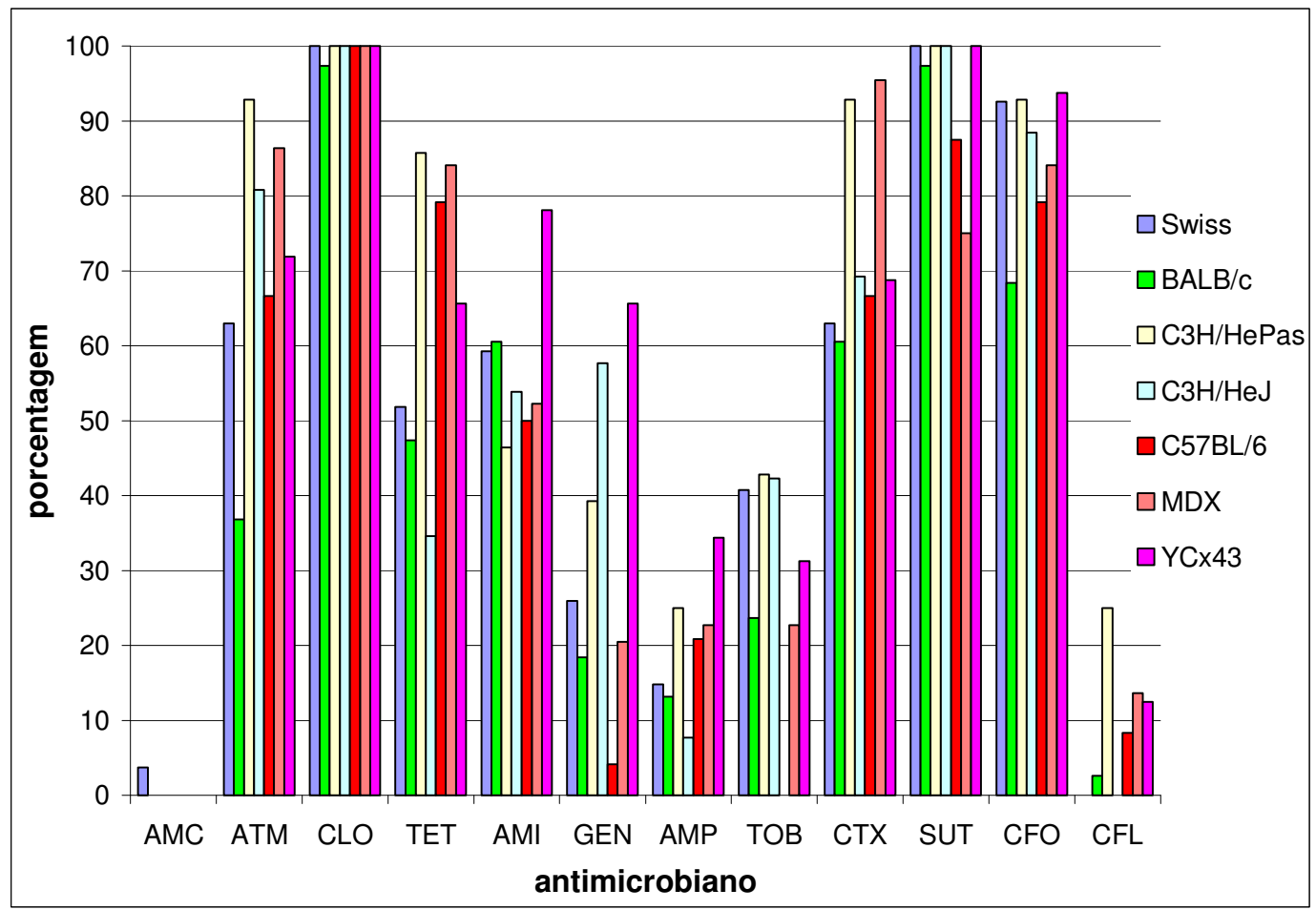

$\mathrm{AMC}=$ amoxicilina, $\mathrm{ATM}=$ aztreonam, $\mathrm{CLO}=$ cloranfenicol, $\mathrm{TET}=$ tetraciclina, $\mathrm{AMI}=$ amicacina, GEN = gentamicina, $\mathrm{AMP}=$ ampicilina, $\mathrm{TOB}=$ tobramicina, $\mathrm{CTX}=$ cefotaxima, $\mathrm{SUT}=$ sulfa+trimetoprin, $\mathrm{CFO}=$ cefoxitina e $\mathrm{CFL}=$ cefalotina.

Gráfico 4 - Porcentagem das E. coli sensíveis aos antimicrobianos testados nas linhagens de camundongos

Com esses dados foi então realizado o teste exato de Fisher $(\alpha=0,05)$, que comparou as freqüências de resultados "resistente", "intermediário" e "sensível" apresentados pelas E. coli de cada linhagem de camundongo, obtendo os p-valores apresentados na tabela 8. 
Tabela 8 - P-valores encontrados no teste exato de Fisher realizado com os resultados dos antibiogramas

\begin{tabular}{lc}
\hline Antimicrobiano & $\mathrm{p}$-valor \\
\hline Amoxicilina & 0.130631 \\
Aztreonam & $<0.001^{*}$ \\
Cloranfenicol & $0.027109^{*}$ \\
Tetraciclina & $<0.001^{*}$ \\
Amicacina & $<0.001^{*}$ \\
Gentamicina & $<0.001^{*}$ \\
Ampicilina & $<0.001^{*}$ \\
Tobramicina & $<0.001^{*}$ \\
Cefotaxima & $<0.001^{*}$ \\
Sulfa + & \\
Trimetoprin & $<0.001^{*}$ \\
Cefoxitina & $<0.001^{*}$ \\
Cefalotina & $<0.001^{*}$ \\
\hline * valores significativos de $\mathrm{p}$
\end{tabular}

Pode-se concluir então que, com exceção da amoxicilina, todas as linhagens responderam de forma diferente a todos os antibióticos $(\mathrm{p}<0,05)$.

Foram então realizados dois testes de ANOVA $(\alpha=0,05)$ a fim de verificar quais linhagens apresentaram mais de 50\% de resistência e sensibilidade aos antimicrobianos. Estes testes não foram feitos para aqueles que apresentaram porcentagens iguais a 0 ou $100 \%$ (variância igual a zero) (Tabelas 9 e 10). 
Tabela 9 - P-valores encontrados no teste de ANOVA para testar quais linhagens de camundongos apresentaram mais de 50\% de resistência aos antimicrobianos

\begin{tabular}{lcccccccc} 
& Swiss & BALB/c & C3H/HePas & C3H/HeJ & C57BL/6 & MDX & YCX43 \\
\hline Amoxicilina & $>0,001^{*}$ & $\mathrm{~b}$ & $\mathrm{~b}$ & $\mathrm{~b}$ & $\mathrm{~b}$ & $\mathrm{~b}$ & $\mathrm{~b}$ \\
Aztreonam & 1 & 1 & $\mathrm{a}$ & $\mathrm{a}$ & 1 & 1 & $\mathrm{a}$ \\
Cloranfenicol & $\mathrm{a}$ & 1 & $\mathrm{a}$ & $\mathrm{a}$ & $\mathrm{a}$ & $\mathrm{a}$ & $\mathrm{a}$ \\
Tetraciclina & 1 & 1 & 1 & 1 & $\mathrm{a}$ & 1 & $\mathrm{a}$ \\
Amicacina & 1 & 0,975 & 0,770 & 1 & 0,981 & 0,884 & 1 \\
Gentamicina & 0,827 & 0,099 & 0,230 & 1 & $0,019^{*}$ & $>0,001^{*}$ & 1 \\
Ampicilina & 0,827 & 0,375 & 0,500 & 0,649 & 0,500 & 0,500 & 1 \\
Tobramicina & 1 & 0,989 & 0,230 & 0,992 & 0,500 & $>0,001^{*}$ & 1 \\
Cefotaxima & $\mathrm{a}$ & 1 & $\mathrm{a}$ & $\mathrm{a}$ & $\mathrm{a}$ & $\mathrm{a}$ & $\mathrm{a}$ \\
Sulfa+Trimetoprim & $\mathrm{a}$ & $\mathrm{a}$ & $\mathrm{a}$ & $\mathrm{a}$ & 1 & 1 & $\mathrm{a}$ \\
Cefoxitina & 1 & 1 & 1 & $\mathrm{a}$ & 1 & 1 & 1 \\
Cefalotina & $\mathrm{b}$ & $>0,001^{*}$ & $0,029^{*}$ & $\mathrm{~b}$ & $>0,001^{*}$ & $>0,001^{*}$ & $>0,001^{*}$ \\
\hline$*=$ valores significativos de p & \multicolumn{7}{c}{} & \\
a = teste não realizado por apresentar resultado de porcentagem igual à zero & & \\
b = teste não realizado por apresentar resultado de porcentagem igual à $100 \%$ & &
\end{tabular}

As E. coli testadas apresentaram maior resistência aos antimicrobianos amoxicilina e cefalotina em todas as linhagens estudadas. Para gentamicina, as bactérias dos camundongos apresentaram maior resistência nos camundongos C57BL/6 e MDX, sendo que neste último as $E$. coli também foram mais resistente a tobramicina. 
Tabela 10 - P-valores encontrados no teste de ANOVA para testar quais linhagens apresentaram mais de $50 \%$ de sensibilidade aos antimicrobianos

\begin{tabular}{|c|c|c|c|c|c|c|c|}
\hline & Swiss & BALB/c & $\mathrm{C} 3 \mathrm{H} / \mathrm{HePas}$ & $\mathrm{C} 3 \mathrm{H} / \mathrm{HeJ}$ & C57BL/6 & MDX & YCX43 \\
\hline Amoxicilina & 1 & $a$ & $a$ & $a$ & $a$ & $a$ & $a$ \\
\hline Aztreonam & 0,091 & 0,947 & $>0,001^{*}$ & $>0,001^{*}$ & 0,052 & $>0,001^{*}$ & $0,005^{\star}$ \\
\hline Cloranfenicol & $\mathrm{b}$ & $>0,001^{*}$ & b & b & b & b & b \\
\hline Tetraciclina & 0,426 & 0,625 & $>0,001^{*}$ & 0,941 & $0,001^{*}$ & $>0,001^{*}$ & $0,038^{*}$ \\
\hline Amicacina & 0,173 & 0,099 & 0,644 & 0,351 & 0,500 & 0,383 & $>0,001^{*}$ \\
\hline Gentamicina & 0,995 & 1 & 0,868 & 0,222 & 1 & 1 & $0,038^{*}$ \\
\hline Ampicilina & 1 & 1 & 0,997 & 1 & 0,999 & 1 & 0,962 \\
\hline Tobramicina & 0,827 & 1 & 0,770 & 0,778 & $a$ & 1 & 0,984 \\
\hline Cefotaxima & 0,091 & 0,099 & $>0,001^{*}$ & $0,024^{*}$ & 0,052 & $>0,001^{*}$ & $0,016^{*}$ \\
\hline Sulfa+Trimetoprim & b & $>0,001^{*}$ & $\mathrm{~b}$ & $\mathrm{~b}$ & $>0,001^{*}$ & $>0,001^{*}$ & $b$ \\
\hline Cefoxitina & $>0,001^{*}$ & $0,011^{*}$ & $>0,001^{*}$ & $>0,001^{*}$ & $>0,001^{*}$ & $>0,001^{*}$ & $>0,001^{*}$ \\
\hline Cefalotina & $\mathrm{a}$ & 1 & 0,997 & $\mathrm{a}$ & 1 & 1 & 1 \\
\hline
\end{tabular}

Maior sensibilidade da E. coli, em todas as linhagens, foi observada frente aos antimicrobianos cloranfenicol, sulfa + trimetoprim e cefoxitina. Para aztreonam, as bactérias mais sensíveis foram isoladas das linhagens C3H/HePas, C3H/HeJ, MDX e YCX43.

As E. coli das linhagens $\mathrm{C} 3 \mathrm{H} / \mathrm{HePas}$ e $\mathrm{MDX}$ apresentaram maior sensibilidade a tetraciclina, sendo obtido o mesmo resultado no caso do antimicrobiano cefotaxima. Amicacina apresentou mais de 50\% de sensibilidade apenas na linhagem YCX43.

Das 219 amostras testadas, apenas 19 (8,68\%) apresentaram resistência a um único antimicrobiano (amoxicilina), e as outras 200 (91,32) foram resistentes a dois ou mais antimicrobianos, ocorrendo 48 diferentes combinações entre eles. Uma amostra foi resistente a, no máximo, oito antimicrobianos concomitantemente. A resistência múltipla (estirpes resistentes a três ou mais antimicrobianos) foi observada em 154 (70\%) amostras, e a combinação mais freqüente ocorreu entre os antimicrobianos amoxicilina, cefalotina, amicacina, gentamicina, ampicilina e tobramicina $(12,99 \%)$ (Tabela 11$)$ 
Tabela 11 - Frequiência de resistência múltipla de E. coli aos antimicrobianos nas linhagens de camundongos estudadas

\begin{tabular}{|c|c|c|c|c|c|c|c|c|c|}
\hline Antimicrobiano & Swiss & BALB/c & $\mathrm{C} 3 \mathrm{H} / \mathrm{HePas}$ & $\mathrm{C} 3 \mathrm{H} / \mathrm{HeJ}$ & C57BL/6 & MDX & $\mathrm{YCx43}$ & Total & Porcentagem \\
\hline$\overline{A M C-C F L-A M P}$ & 1 & 5 & 1 & 7 & 2 & 0 & 2 & 18 & 11,69 \\
\hline AMC-CFL-GEN & 3 & 5 & 0 & 3 & 1 & 0 & 1 & 13 & 8,44 \\
\hline AMC-CFL-TOB & 0 & 0 & 0 & 2 & 0 & 0 & 4 & 6 & 3,90 \\
\hline AMC-CFL-AMI & 1 & 0 & 0 & 1 & 0 & 0 & 2 & 4 & 2,60 \\
\hline AMC-CFL-ATM & 1 & 0 & 0 & 0 & 0 & 0 & 0 & 1 & 0,65 \\
\hline AMC-CFL-TET & 1 & 0 & 0 & 0 & 0 & 0 & 0 & 1 & 0,65 \\
\hline AMC-GEN-AMP & 0 & 0 & 0 & 0 & 1 & 0 & 0 & 1 & 0,65 \\
\hline AMC-GEN-TOB & 0 & 0 & 0 & 0 & 0 & 1 & 0 & 1 & 0,65 \\
\hline$\overline{\text { AMC-CFL-ATM-TOB }}$ & 0 & 0 & 0 & 0 & 1 & 1 & 0 & 2 & 1,30 \\
\hline AMC-CFL-GEN-AMP & 4 & 1 & 0 & 1 & 4 & 0 & 0 & 10 & 6,49 \\
\hline AMC-CFL-GEN-TOB & 0 & 0 & 0 & 0 & 4 & 5 & 0 & 9 & 5,84 \\
\hline AMC-CFL-AMP-TOB & 0 & 1 & 0 & 2 & 1 & 0 & 0 & 4 & 2,60 \\
\hline AMC-CFL-AMI-TOB & 0 & 1 & 0 & 1 & 0 & 1 & 0 & 3 & 1,95 \\
\hline AMC-CFL-AMI-CFO & 0 & 1 & 0 & 0 & 0 & 0 & 0 & 1 & 0,65 \\
\hline AMC-CFL-AMP-CFO & 0 & 0 & 0 & 0 & 1 & 0 & 0 & 1 & 0,65 \\
\hline AMC-CFL-AMP-CTX & 0 & 1 & 0 & 0 & 0 & 0 & 0 & 1 & 0,65 \\
\hline AMC-CFL-TET-AMP & 0 & 0 & 0 & 1 & 0 & 0 & 0 & 1 & 0,65 \\
\hline AMC-CFL-AMI-GEN & 0 & 0 & 0 & 0 & 1 & 0 & 0 & 1 & 0,65 \\
\hline AMC-CFL-TET-TOB & 1 & 0 & 0 & 0 & 0 & 0 & 0 & 1 & 0,65 \\
\hline AMC-AMI-GEN-TOB & 0 & 0 & 0 & 0 & 0 & 1 & 0 & 1 & 0,65 \\
\hline$\overline{\text { AMC-CFL-AMP-GEN-TOB }}$ & 1 & 2 & 3 & 0 & 0 & 9 & 0 & 15 & 9,74 \\
\hline AMC-CFL-AMI-GEN-TOB & 0 & 3 & 3 & 0 & 2 & 4 & 0 & 12 & 7,79 \\
\hline AMC-CFL-AMI-GEN-AMP & 3 & 1 & 0 & 0 & 1 & 0 & 0 & 5 & 3,25 \\
\hline AMC-CFL-TET-AMI-TOB & 0 & 0 & 0 & 1 & 0 & 0 & 0 & 1 & 0,65 \\
\hline AMC-CFL-TET-AMI-GEN & 0 & 1 & 0 & 0 & 0 & 0 & 0 & 1 & 0,65 \\
\hline AMC-CFL-TET-AMI-AMP & 0 & 1 & 0 & 0 & 0 & 0 & 0 & 1 & 0,65 \\
\hline AMC-CFL-GEN-AMP-SUT & 0 & 1 & 0 & 0 & 0 & 0 & 0 & 1 & 0,65 \\
\hline AMC-CFL-AMI-GEN-SUT & 0 & 0 & 0 & 0 & 1 & 0 & 0 & 1 & 0,65 \\
\hline AMC-CFL-TET-GEN-AMP & 0 & 1 & 0 & 0 & 0 & 0 & 0 & 1 & 0,65 \\
\hline AMC-CFL-AMI-AMP-TOB & 0 & 0 & 0 & 1 & 0 & 0 & 0 & 1 & 0,65 \\
\hline AMC-CFL-AMI-AMP-CFO & 1 & 0 & 0 & 0 & 0 & 0 & 0 & 1 & 0,65 \\
\hline$\overline{\text { AMC-CFL-TET-GEN-AMP-TOB }}$ & 0 & 0 & 1 & 0 & 0 & 0 & 0 & 1 & 0,65 \\
\hline AMC-CFL-AMI-GEN-AMP-CFO & 0 & 0 & 0 & 0 & 0 & 1 & 0 & 1 & 0,65 \\
\hline AMC-CFL-TET-AMI-GEN-AMP & 0 & 1 & 0 & 0 & 0 & 0 & 0 & 1 & 0,65 \\
\hline AMC-CFL-AMI-GEN-TOB-SUT & 0 & 0 & 0 & 0 & 1 & 0 & 0 & 1 & 0,65 \\
\hline AMC-CFL-GEN-AMP-TOB-SUT & 0 & 0 & 0 & 0 & 0 & 1 & 0 & 1 & 0,65 \\
\hline AMC-CFL-GEN-AMP-TOB-CFO & 0 & 1 & 0 & 0 & 1 & 0 & 1 & 3 & 1,95 \\
\hline AMC-CFL-CLO-AMI-GEN-AMP & 0 & 2 & 0 & 0 & 0 & 0 & 0 & 2 & 1,30 \\
\hline AMC-CFL-AMI-GEN-AMP-TOB & 0 & 1 & 9 & 0 & 1 & 9 & 0 & 20 & 12,99 \\
\hline AMC-CFL-AMI-GEN-AMP-TOB-SUT & 0 & 0 & 0 & 0 & 0 & 1 & 0 & 1 & 0,65 \\
\hline AMC-CFL-TET-AMI-GEN-AMP-TOB & 0 & 0 & 0 & 0 & 0 & 1 & 0 & 1 & 0,65 \\
\hline AMC-CFL-ATM-AMI-GEN-AMP-TOB-CTX & 0 & 1 & 0 & 0 & 0 & 0 & 0 & 1 & 0,65 \\
\hline AMC-CFL-TET-GEN-AMP-TOB-CTX-CFO & 0 & 1 & 0 & 0 & 0 & 0 & 0 & 1 & 0,65 \\
\hline Total & 17 & 32 & 17 & 20 & 23 & 35 & 10 & 154 & 100,00 \\
\hline
\end{tabular}

$\mathrm{AMC}=$ amoxicilina, $\mathrm{ATM}=$ aztreonam, $\mathrm{CLO}=$ cloranfenicol, $\mathrm{TET}=$ tetraciclina, $\mathrm{AMI}=$ amicacina, GEN $=$ gentamicina, $\mathrm{AMP}=$ ampicilina, $\mathrm{TOB}=$ tobramicina, $\mathrm{CTX}=$ cefotaxima, $\mathrm{SUT}=\quad$ sulfa+trimetoprin, $\mathrm{CFO}=$ cefoxitina e $\mathrm{CFL}=$ cefalotina.

Os índices de resistência múltipla (IRM) encontrados estão representados na tabela 12. 
Tabela 12 - Resultados dos índices de resistência múltipla (IRM) calculados para as linhagens de camundongos estudadas

\begin{tabular}{cccccccc} 
& Swiss & BALB/c & $\mathrm{C} 3 \mathrm{H} / \mathrm{HePas}$ & $\mathrm{C} 3 \mathrm{H} / \mathrm{HeJ}$ & $\mathrm{C} 57 \mathrm{BL} / 6$ & $\mathrm{MDX}$ & $\mathrm{YCX} 43$ \\
\hline IRM & 0,27 & 0,35 & 0,32 & 0,26 & 0,34 & 0,36 & 0,19 \\
\hline
\end{tabular}

Esses índices foram comparados dois a dois através do teste t de Student $(\alpha=0,05)$ e obteve-se 21 p-valores (Tabela 13). 
Tabela 13 - P-valores das comparações dos índices de resistência múltipla (IRM) entre as linhagens de camundongos estudadas

\begin{tabular}{lc}
\hline Linhagens comparadas & p-valor \\
\hline Swiss - BALB/c & $0,0009^{*}$ \\
Swiss - C3H/HePas & 0,0599 \\
Swiss - C3H/HeJ & 0,5244 \\
Swiss - C57BL/6 & $0,0043^{*}$ \\
Swiss - MDX & $0,0001^{*}$ \\
Swiss - YCx43 & $0,0002^{*}$ \\
BALB/c - C3H/HePas & 0,1916 \\
BALB/c - C3H/HeJ & $0,0001^{*}$ \\
BALB/c - C57BL/6 & 0,9029 \\
BALB/c - MDX & 0,3691 \\
BALB/c - YCx43 & $0,0001^{*}$ \\
C3H/HePas - C3H/HeJ & $0,0123^{*}$ \\
C3H/HePas - C57BL/6 & 0,2915 \\
C3H/HePas - MDX & $0,0302^{*}$ \\
C3H/HePas - YCx43 & $0,0001^{*}$ \\
C3H/HeJ - C57BL/6 & $0,0006^{*}$ \\
C3H/HeJ - MDX & $0,0001^{*}$ \\
C3H/HeJ - YCx43 & $0,0023^{*}$ \\
C57BL/6 - MDX & 0,3633 \\
C57BL/6 - YCx43 & $0,0001^{*}$ \\
MDX - YCx43 & $0,0001^{*}$ \\
\hline * = valores significativos de p
\end{tabular}

$\mathrm{BALB} / \mathrm{c}$ apresentou maior índice de resistência múltipla do que Swiss, C3H/HePas e $\mathrm{C} 3 \mathrm{H} / \mathrm{HeJ}$; maior índice também foi observado em $\mathrm{C} 3 \mathrm{H} / \mathrm{HePas}$ que $\mathrm{C} 3 \mathrm{H} / \mathrm{HeJ}$; C57BL/6 maior que Swiss e C3H/HeJ; MDX maior que Swiss, C3H/HePas e C3H/HeJ; e YCx43 foi menor que todas as outras seis linhagens. 
ESTUDO DA PRESENÇA DE FATORES DE VIRULÊNCIA EM ESTIRPES DE E. coli ISOLADAS DAS FEZES DOS ANIMAIS UTILIZANDO A REAÇÃO EM CADEIA DA POLIMERASE

Foram realizadas 219 PCR, e não se encontrou nenhum fator de virulência.

\section{ISOLAMENTO E IDENTIFICAÇÃO DOS MICRORGANISMOS PRESENTES NO AMBIENTE E LUVAS DOS MANIPULADORES}

Para cada uma das três salas de camundongos do biotério foram coletados dez suabes da mesa, maçaneta das portas e do exterior das luvas utilizadas pelos funcionários, antes da limpeza de mesas e portas. A freqüência e porcentagem das bactérias isoladas nas salas estão representadas na tabela 14 e gráficos 5, 6, 7, 8. Nos mesmos dias das coletas, as placas de Petri com os meios de cultura também eram abertas nas salas (Tabela 15). 
Tabela 14 - Freqüência(n) e porcentagem (p) das bactérias isoladas das três salas de camundongos - São Paulo, agosto.2006 - fevereiro. 2007

\begin{tabular}{|c|c|c|c|c|c|c|c|c|c|c|}
\hline Local & Sala & & $\begin{array}{c}\text { Staphylococcus } \\
\text { spp } \\
\end{array}$ & $\begin{array}{c}\text { Streptococcus } \\
\mathrm{spp} \\
\end{array}$ & $\begin{array}{c}\text { Micrococcus } \\
\text { lylae }\end{array}$ & $\begin{array}{c}\text { Micrococcus } \\
\text { spp } \\
\end{array}$ & $\begin{array}{c}\text { Bacillus } \\
\text { spp }\end{array}$ & $\begin{array}{c}\text { Enterococcus } \\
\text { spp } \\
\end{array}$ & $\begin{array}{c}\text { E. tarda } \\
\text { biogrupo } 1\end{array}$ & $\begin{array}{r}\text { K. penumoniae } \\
\text { subsp azanae }\end{array}$ \\
\hline \multirow{6}{*}{ ar } & 1 & $\mathrm{n}$ & 9 & 4 & 0 & 0 & 6 & 2 & 0 & 0 \\
\hline & & $\mathrm{p}$ & 90 & 40 & 0 & 0 & 60 & 20 & 0 & 0 \\
\hline & 2 & $\mathrm{n}$ & 10 & 1 & 0 & 1 & 7 & 2 & 0 & 0 \\
\hline & & $\mathrm{p}$ & 100 & 10 & 0 & 10 & 70 & 20 & 0 & 0 \\
\hline & 3 & $\mathrm{n}$ & 8 & 0 & 0 & 2 & 7 & 4 & 0 & 0 \\
\hline & & $\mathrm{p}$ & 80 & 0 & 0 & 20 & 70 & 40 & 0 & 0 \\
\hline \multirow{6}{*}{ mesa } & 1 & $\mathrm{n}$ & 8 & 1 & 2 & 1 & 7 & 6 & 2 & 0 \\
\hline & & $\mathrm{p}$ & 80 & 10 & 20 & 10 & 70 & 60 & 20 & 0 \\
\hline & 2 & $\mathrm{n}$ & 8 & 0 & 3 & 0 & 5 & 4 & 1 & 0 \\
\hline & & $\mathrm{p}$ & 80 & 0 & 30 & 0 & 50 & 40 & 10 & 0 \\
\hline & 3 & $\mathrm{n}$ & 7 & 3 & 1 & 2 & 6 & 5 & 1 & 0 \\
\hline & & $\mathrm{p}$ & 70 & 30 & 10 & 20 & 60 & 50 & 10 & 0 \\
\hline \multirow{6}{*}{ porta } & 1 & $\mathrm{n}$ & 6 & 1 & 3 & 2 & 5 & 2 & 0 & 0 \\
\hline & & $\mathrm{p}$ & 60 & 10 & 30 & 20 & 50 & 20 & 0 & 0 \\
\hline & 2 & $\mathrm{n}$ & 8 & 1 & 1 & 0 & 7 & 1 & 0 & 0 \\
\hline & & $\mathrm{p}$ & 80 & 10 & 10 & 0 & 70 & 10 & 0 & 0 \\
\hline & 3 & $\mathrm{n}$ & 9 & 1 & 0 & 0 & 3 & 3 & 0 & 0 \\
\hline & & $\mathrm{p}$ & 90 & 10 & 0 & 0 & 30 & 30 & 0 & 0 \\
\hline \multirow{6}{*}{ luva } & 1 & $\mathrm{n}$ & 10 & 0 & 1 & 1 & 3 & 3 & 1 & 1 \\
\hline & & $\mathrm{p}$ & 100 & 0 & 10 & 10 & 30 & 30 & 10 & 10 \\
\hline & 2 & $\mathrm{n}$ & 10 & 1 & 1 & 1 & 5 & 3 & 0 & 0 \\
\hline & & $\mathrm{p}$ & 100 & 10 & 10 & 10 & 50 & 30 & 0 & 0 \\
\hline & 3 & $\mathrm{n}$ & 7 & 0 & 3 & 2 & 7 & 5 & 0 & 1 \\
\hline & & $\mathrm{p}$ & 70 & 0 & 30 & 20 & 70 & 50 & 0 & 10 \\
\hline \multirow{2}{*}{$\begin{array}{c}\text { luva } \\
\text { não utilizada }\end{array}$} & & $\mathrm{n}$ & 3 & 0 & 0 & 0 & 7 & 0 & 0 & 0 \\
\hline & & $\mathrm{p}$ & 30 & 0 & 0 & 0 & 70 & 0 & 0 & 0 \\
\hline
\end{tabular}

$\mathrm{n}=$ número de amostras isoladas

$\mathrm{p}=$ porcentagem $(\mathrm{n} /$ número de coletas $\mathrm{x} 100)$

sala $1=$ Swiss, C57BL/6, C3H/HePas; sala 2 = BALB/c, C3H/HeJ, MDX; sala $3=$ YCX43. 


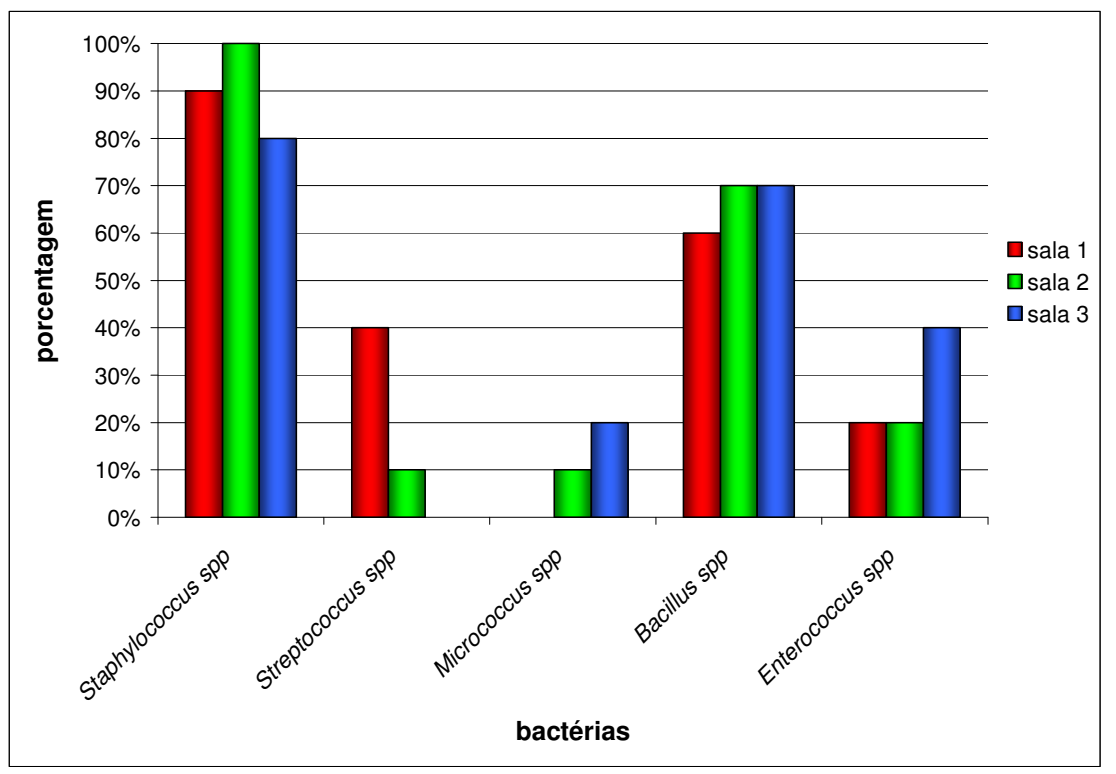

sala $1=$ Swiss, C57BL/6, C3H/HePas; sala $2=\mathrm{BALB} / \mathrm{c}, \mathrm{C} 3 \mathrm{H} / \mathrm{HeJ}$, MDX; sala $3=$ YCX43.

Gráfico 5 - Porcentagem das bactérias isoladas no ar das nas três salas de camundongos

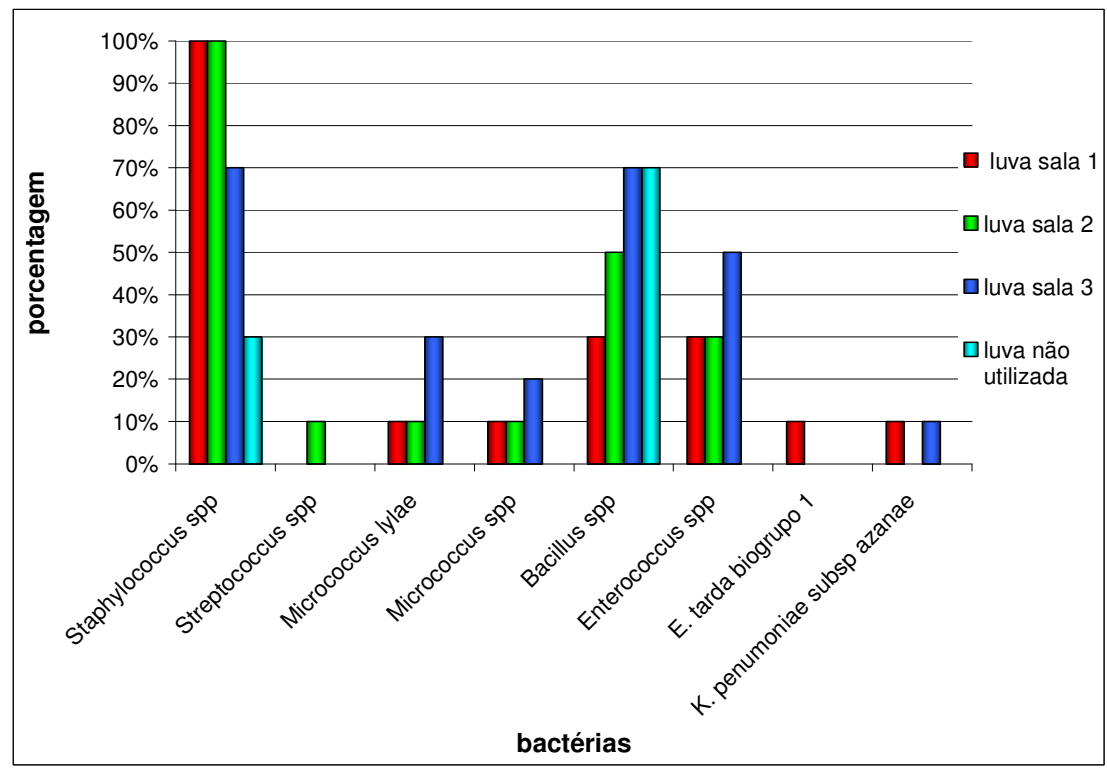

sala $1=$ Swiss, C57BL/6, C3H/HePas; sala $2=\mathrm{BALB} / \mathrm{c}, \mathrm{C} 3 \mathrm{H} / \mathrm{HeJ}, \mathrm{MDX}$ sala $3=$ YCX43.

Gráfico 6 - Porcentagem das bactérias isoladas nas luvas das três salas de camundongos e luvas não utilizadas 


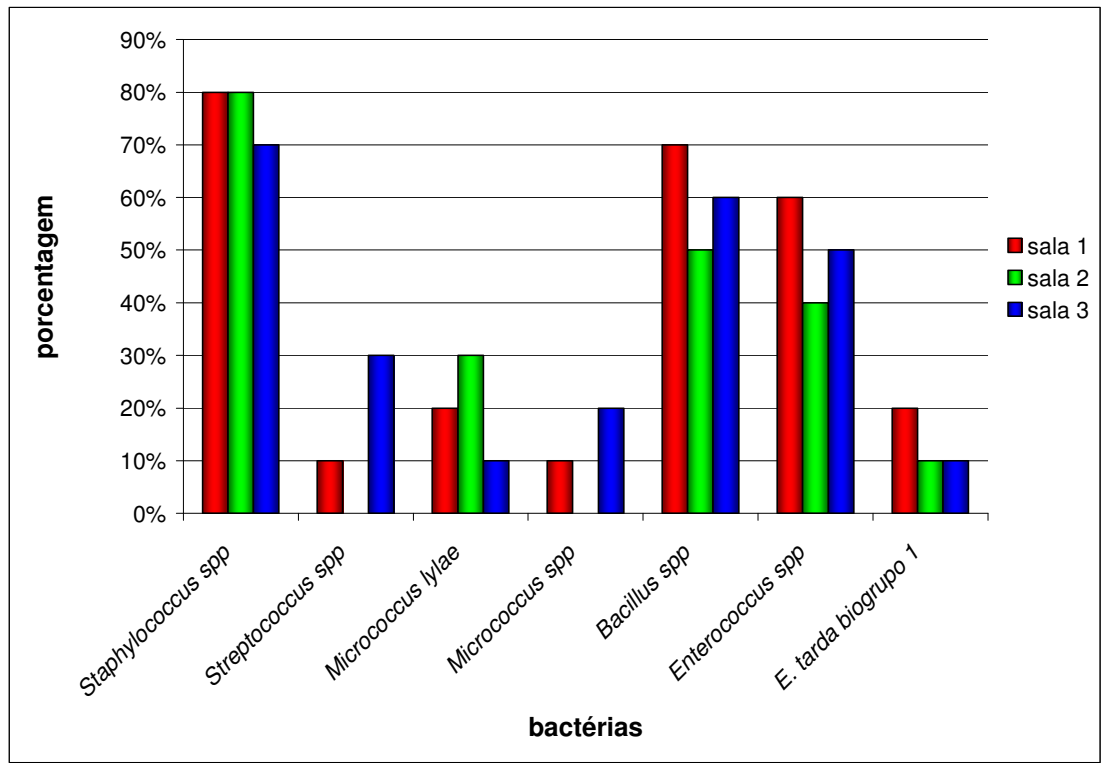

sala $1=$ Swiss, C57BL/6, C3H/HePas; sala $2=\mathrm{BALB} / \mathrm{c}, \mathrm{C} 3 \mathrm{H} / \mathrm{HeJ}, \mathrm{MDX}$ sala $3=$ YCX43.

Gráfico 7 - Porcentagem das bactérias isoladas nas mesas das três salas de camundongos

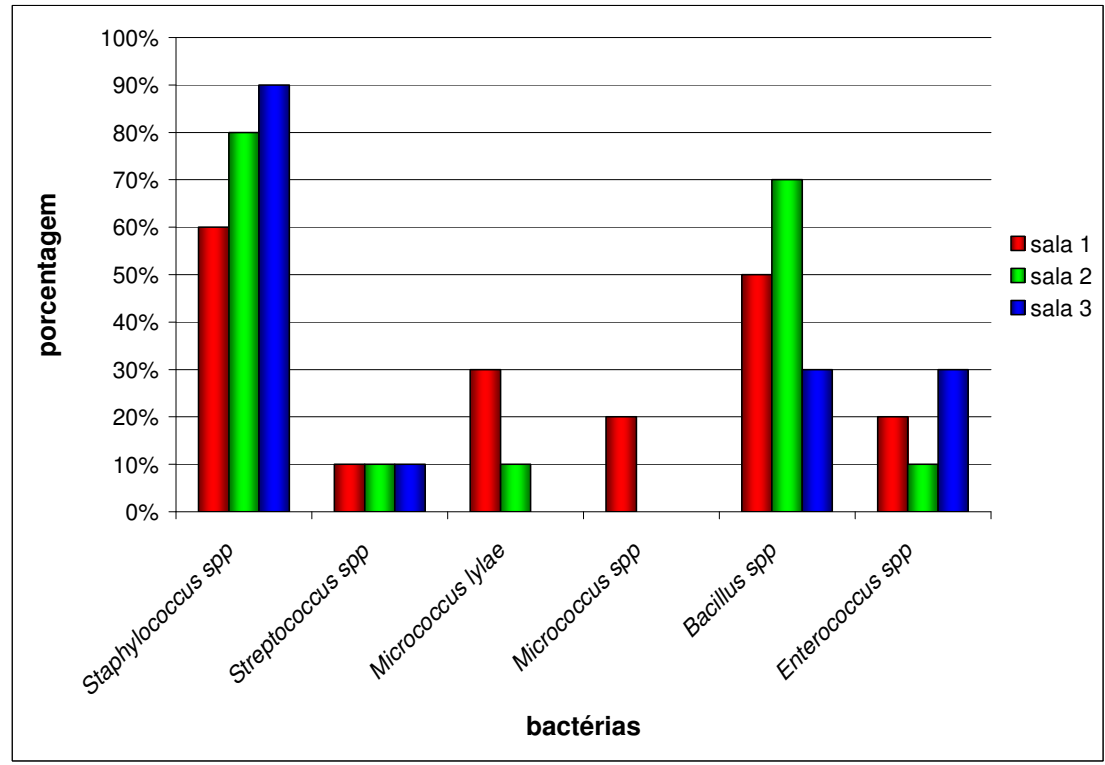

sala $1=$ Swiss, C57BL/6, C3H/HePas; sala $2=\mathrm{BALB} / \mathrm{c}, \mathrm{C} 3 \mathrm{H} / \mathrm{HeJ}, \mathrm{MDX}$ sala $3=$ YCX43

Gráfico 8 - Porcentagem das bactérias isoladas nas maçanetas das portas das três salas de camundongos 
Tabela 15 - Estatística descritiva da contagem de unidades formadoras de colônia (ufc) realizada nas três salas de camundongos - São Paulo, agosto.2006 - fevereiro.2007

\begin{tabular}{|c|c|c|c|c|c|c|c|}
\hline Bactéria & Sala & Média & Máximo & Mínimo & Mediana & Variância & $\begin{array}{l}\text { Coeficiente de } \\
\text { variação* }\end{array}$ \\
\hline \multirow{3}{*}{ Staphylococcus spp } & 1 & 8.8 & 31 & 2 & 6.5 & 73.1 & 97.1 \\
\hline & 2 & 10.3 & 32 & 2 & 8.5 & 83.8 & 88.9 \\
\hline & 3 & 4.3 & 29 & 0 & 1.5 & 76.7 & 203.6 \\
\hline \multirow{3}{*}{ Streptococcus spp } & 1 & 0.7 & 5 & 0 & 0 & 2.5 & 223.9 \\
\hline & 2 & 0.1 & 1 & 0 & 0 & 0.1 & 316.2 \\
\hline & 3 & 0 & 0 & 0 & 0 & 0 & - \\
\hline \multirow{3}{*}{ Micrococcus spp } & 1 & 0 & 0 & 0 & 0 & 0 & - \\
\hline & 2 & 0 & 0 & 0 & 0 & 0 & - \\
\hline & 3 & 0.7 & 6 & 0 & 0 & 3.6 & 269.8 \\
\hline \multirow{3}{*}{ Bacillus spp } & 1 & 1.3 & 3 & 0 & 1 & 1.8 & 102.9 \\
\hline & 2 & 1.3 & 4 & 0 & 1 & 1.6 & 96.3 \\
\hline & 3 & 1.6 & 7 & 0 & 1 & 4.5 & 132.4 \\
\hline \multirow{4}{*}{ Enterococcus spp } & 1 & 0.9 & 5 & 0 & 0 & 3.7 & 212.4 \\
\hline & 2 & 0.2 & 1 & 0 & 0 & 0.2 & 210.8 \\
\hline & 3 & 0.8 & 4 & 0 & 0 & 2.2 & 184.5 \\
\hline & 1 & 0.5 & 5 & 0 & 0 & 2.5 & 316.2 \\
\hline
\end{tabular}

Edw. tarda (biogrupo

\begin{tabular}{cccccccc}
$E d w . \operatorname{tarda}$ (biogrupo & & & & & & \\
1 ) & 2 & 0 & 0 & 0 & 0 & 0 & - \\
\hline
\end{tabular}

* (desvio padrão / média) x 100\%

sala 1 = Swiss, C57BL/6, C3H/HePas; sala 2 = BALB/c, C3H/HeJ, MDX; sala $3=\mathrm{YCx} 43$.

$\mathrm{Edw}=$ Edwardsiella

Ao realizar um teste de MANOVA para comparar a contagem de unidades formadoras de colônia das três salas, obteve-se um p-valor de 0,4045, concluindo que as salas apresentam número de ufc iguais.

A fim de saber se as luvas utilizadas nas diferentes salas e as não utilizadas apresentaram resultados microbiológicos iguais, foi realizado um teste de MANOVA $(\alpha=0,05)$. Encontrou-se um p-valor de 0,0022, que indica que as freqüências de bactérias nas luvas eram diferentes.

Foi então realizado um novo teste de MANOVA $(\alpha=0,05)$, que testava a frequiência de cada bactéria nas diferentes luvas, encontrando os p-valores da tabela 16. 
Tabela 16 - P-valores encontrados no teste de MANOVA para as bactérias isoladas nas luvas das três salas de camundongos

\begin{tabular}{lc}
\hline Bactéria & p-valor \\
\hline Staphylococcus spp & $<0,0001^{*}$ \\
Streptococcus spp & 0,404 \\
Micrococcus lylae & 0,241 \\
Micrococcus spp & 0,554 \\
Bacillus spp & 0,231 \\
Enterococcus spp & 0,095 \\
Edw. tarda biogrupo 1 & 0,404 \\
K. penumoniae subsp azanae & 0,578 \\
\hline * valores significantes de $\mathrm{p}$ & \\
Edw = Edwardsiella &
\end{tabular}

Por este teste conclui-se então que a proporção de Staphylococcus spp encontrada é estatisticamente diferente em pelo menos um dos grupos. Então, para verificar qual grupo de luvas era diferente foi realizado mais um teste de MANOVA $(\alpha=0,05)$, comparando a proporção de Staphylococcus spp das luvas utilizadas com as não utilizadas. Foram encontrados os pvalores da tabela 17. 
Tabela 17 - P-valores encontrados no teste de MANOVA para a proporção de Staphylococcus spp encontrados nas luvas das três salas de camundongos

\begin{tabular}{lc}
\cline { 2 - 2 } & $\mathrm{p}$-valor \\
\hline Sala 1 x Luva não usada & $<.0001^{*}$ \\
Sala 2 x Luva não usada & $<.0001^{*}$ \\
Sala 3 x Luva não usada & $0.0128^{*}$ \\
Sala 2 x 1 & 1 \\
Sala 2 x 3 & 0.0573 \\
Sala 1 x 3 & 0.0573 \\
\hline * = valores significantes de p \\
sala 1 = Swiss, C57BL/6, C3H/HePas \\
sala 2 = BALB/c, C3H/HeJ, MDX \\
sala 3 = YCx43
\end{tabular}

Por este último teste conclui-se que a proporção de Staphylococcus spp nas luvas não utilizadas foi menor que nas luvas utilizadas e estas tiveram proporções iguais da bactéria quando comparadas entre elas.

Realizando outros três testes de MANOVA $(\alpha=0,05)$, que comparavam as proporções de bactérias presentes no ar, mesa e maçaneta da porta e encontrou-se os p-valores da tabela 18.

Tabela 18 - P-valores encontrados no teste de MANOVA para estudo da proporção de bactérias presentes no ar, mesa e porta das três salas de camundongos

\begin{tabular}{lc}
\hline Local & $\mathrm{p}$-valor \\
\hline ar & 0.4047 \\
mesa & 0.7125 \\
porta & 0.1878 \\
\hline
\end{tabular}


Verificou-se então que não houve diferença estatisticamente significante na proporção de bactérias encontradas no ar, mesa e porta das três salas de camundongos. 


\section{DISCUSSÃO}

Desde os estudos pioneiros de Schaedler, Dubos e Costello (1965) e Dubos et al. (1965), apenas um limitado número de pesquisas explorou a população gastrointestinal de camundongos utilizando métodos tradicionais de cultura (SALZMAN et al., 2002).

Desses estudos, verificou-se que, dentre a microbiota cultivável do intestino do camundongo, estão os anaeróbios facultativos Lactobacillus spp, Enterobacillus spp e Enterococcus spp (sendo os dois primeiros não isoláveis pelos métodos utilizados neste trabalho), além dos anaeróbios Bacteróides spp e Clostridium spp (DUBOS et al., 1965; SCHAEDLER; DUBOS; COSTELLO, 1965).

Porém, avanços na biologia molecular propõem a idéia de que a maioria das bactérias intestinais não pode ser isolada pelos métodos tradicionais, e sugerem que mais de $90 \%$ dos organismos que fazem parte do trato gastro intestinal ainda não foram identificados (SALZMAN et al., 2002). Tratando-se este trabalho apenas de bactérias aeróbias isoladas por métodos tradicionais de cultivo, infere-se que apenas uma pequena parte da microbiota destes animais foi identificada, sendo necessários ainda muitos estudos a respeito deste tema.

Já é sabido há muitas décadas que a microbiota representa um importante papel na resistência a colonização de bactérias patogênicas e muitos mecanismos têm sido propostos para explicar tal fato, como a produção de substâncias inibitórias, competição por nutrientes ou pelos sítios de adesão (MOMOSE; HIRAYAMA; ITOH, 2007).

Este fato foi demonstrado por Momose, Hirayama e Itoh (2007), quando inocularam diluições de fezes humanas em camundongos germfree, produzindo dois grupos de camundongos BFA (baby flora associated), BFA3 e BFA4. Nas fezes dos camundongos do primeiro grupo foram identificadas 24 espécies de bactérias e sorovares e 16 espécies em BFA4. Ao desafiar esses dois grupos a $E$. coli $\mathrm{O} 157: \mathrm{H} 7$, BFA3 eliminou a bactéria, enquanto BFA4 tornou-se carreador, resultado que demonstrou a importância da microbiota na proteção do animal contra a E. coli $\mathrm{O} 157: \mathrm{H} 7$

Duchet-Suchaux, Maitre e Bertin (1990) verificaram que a suscetibilidade de camundongos neonatos a ETEC variou com a linhagem, sendo Swiss OF1 e CBA altamente suscetíveis e DBA/2, BALB/cBy e C57BL/6 praticamente resistentes. Bertin (1992) encontrou os 
mesmos resultados ao inocular oralmente Sta nas mesmas linhagens e também De Castro et al. (1978) que, ao testarem as linhagens Swiss, C3H/HeJ, AWySn, B10A/jax e C57BL/10J, verificaram ser a primeira a mais suscetível.

Estes pesquisadores sugeriram então que algumas dessas linhagens são mais úteis que outras para a expressão da doença ou para estudar a resistência a colibacilose, uma vez que características como a quantidade de receptores no intestino pode diferir entre as linhagens, havendo conseqüentemente diferenças no efeito dose-resposta. Além disso, esses autores propõem que existem linhagens de camundongos que são altamente suscetíveis ou completamente resistentes à mesma estirpe e sugerem que a expressão da doença pode ser controlada geneticamente. Provavelmente estas afirmações não se apliquem apenas para a ETEC, e sim para todas as bactérias, como demonstrado no presente trabalho, no qual todas as linhagens apresentaram microbiotas diferentes entre si, revelando diferenças de suscetibilidade.

Swiss, C3H/HePas e C57BL/6 foram as linhagens que apresentaram a menor freqüência de E. coli, sem diferenças estatisticamente significantes entre elas, assim como BALB/c, MDX e YCX43, que apresentaram a maior freqüência para esta bactéria. Tais resultados diferem daqueles encontrados por De Castro et al. (1978), Duchet-Suchaux, Maitre e Bertin (1990), Bertin (1992), Conlan e Perry (1998) e com relação à suscetibilidade das linhagens frente à $E$. coli. Porém, é importante também lembrar que as estirpes utilizadas nestes trabalhos eram patogênicas, devendo a suscetibilidade dos animais ser pesquisada para cada uma delas.

Então, para se propor um animal como modelo de estudos para uma estirpe de E. coli deve-se atentar para seu objetivo ou seja, pesquisar a doença ou resistência à bactéria, e utilizar linhagens com maior frequiência para estudar o curso da doença e aquelas com menores freqüências para pesquisar a resistência do hospedeiro.

Necessita-se ainda porém, pesquisar as linhagens com menor freqüência da bactéria (Swiss, C57BL/6, C3H/HePas) a fim de verificar o motivo da maior resistência, se ocorre menor quantidade de receptores para a bactéria no intestino desses animais, como sugerido por De Castro et al. (1978), Duchet-Suchaux, Maitre e Bertin (1990), Bertin (1992), se seu sistema imune é menos eficiente, entre outras possibilidades.

Já é sabido que existem diferenças de suscetibilidade a doenças entre linhagens isogênicas, e em muitas situações isso se deve a anormalidades na resposta imune, como ocorre com a linhagem $\mathrm{C} 3 \mathrm{H} / \mathrm{HeJ}$. A habilidade do macrófago para responder ao LPS da bactéria é 
regulada pelo gene Lps localizado no comossomo murino 4, que é expresso nos camundongos que respondem ao LPS, como no caso dos $\mathrm{C} 3 \mathrm{H} / \mathrm{HeN}$ e $\mathrm{C} 3 \mathrm{H} / \mathrm{OuJ}$, mas não nos que não respondem, como o C3H/HeJ (BUSCHMAN; SKAMENE, 1999; FRANKLIN, 2006).

Porém, inoculando $10^{8}$ UPEC intravesicalmente em camundongos $\mathrm{C} 3 \mathrm{H} / \mathrm{HeN}, \mathrm{C} 3 \mathrm{H} / \mathrm{OuJ}$ e $\mathrm{C} 3 \mathrm{H} / \mathrm{HeJ}$, verificou-se que as duas últimas linhagens mostraram-se igualmente suscetíveis à bactéria e não foram capazes de resolver a infecção. Uma possível explicação seria que $\mathrm{C} 3 \mathrm{H} / \mathrm{HeN}$ possui maior habilidade para produzir anticorpos que as duas outras linhagens (HOPKINS et al., 1996). O mesmo resultado foi observado por Vallance et al. (2003) ao infectar estas três linhagens com $C$. rodentium (que possui uma ilha de patogenicidade LEE semelhante a EPEC e EHEC, causando a lesão A/E), e observar que $\mathrm{C} 3 \mathrm{H} / \mathrm{HeN}$ apresentou sinais clínicos mais tardiamente, assim como seu tempo de sobrevida foi maior que $\mathrm{C} 3 \mathrm{H} / \mathrm{OuJ}$ e $\mathrm{C} 3 \mathrm{H} / \mathrm{HeJ}$. Portanto, este estudo também sugere que a maior suscetibilidade da linhagem $\mathrm{C} 3 \mathrm{H} / \mathrm{HeJ}$ frente à bactéria não se deve apenas a sua não capacidade de responder ao LPS.

O fato destas duas linhagens serem originárias do mesmo local (Jackson Laboratory) é importante, pois são imunogeneticamente mais similares entre si quando comparadas com a $\mathrm{C} 3 \mathrm{H} / \mathrm{HeN}$. Elas teriam um repertório de anticorpos anti-E. coli mais parecido e conseqüentemente uma resposta similar frente à bactéria (HOPKINS et al., 1996).

Talvez o mesmo raciocínio possa se aplicar à comparação das microbiotas isoladas de $\mathrm{C} 3 \mathrm{H} / \mathrm{HeJ}$ e $\mathrm{C} 3 \mathrm{H} / \mathrm{HePas}$, uma vez que a primeira é originária do Jackson Laboratory e a outra do Instituto Pasteur, são também distantes imunogeneticamente, apesar de procederem da mesma linhagem $\mathrm{C} 3 \mathrm{H}$.

Em infecções experimentais portanto, a linhagem $\mathrm{C} 3 \mathrm{H} / \mathrm{HeJ}$ não se apresentou mais resistente a bactérias Gram negativas que outras linhagens, e no presente estudo estes animais apresentaram maior freqüência de Gram negativas apenas para S. marcencens e ainda foi a que apresentou maior freqüência de Staphylococcus spp.

Acredita-se que, por se tratar de animais saudáveis, mantidos em condições controladas, a freqüência de Gram negativos nesta linhagem não deveria ser alta, caso contrário os animais adoeceriam, e a alta quantidade de Staphylococcus spp encontrados no ambiente pode ter contribuído para este resultado. A $S$. marcencens, que além da $\mathrm{C} 3 \mathrm{H} / \mathrm{HeJ}$, só foi isolada na linhagem $\mathrm{BALB} / \mathrm{c}$, sem diferença estatística entre elas, encontra-se em condições que não causa 
doença nos animais. A freqüência de Staphylococcus spp nos C3H/HeJ também não apresentou diferença estatística com a dos BALB/c.

$\mathrm{O}$ aparecimento de camundongos geneticamente modificados gerou preocupações sobre o surgimento de novos impactos causados por agentes microbianos, uma vez que os animais poderiam ser mais suscetíveis do que linhagens isogênicas ou heterogênicas. Além disso, a manifestação da doença também pode variar em razão de interações entre o novo hospedeiro com o agente (FRANKLIN, 2006).

Assim como nas outras seis linhagens estudadas, E. coli apresentou-se com maior freqüência nos YCx43 (80\%), que também foi a que apresentou maior frequiência de Streptococcus spp (72,5\%). Porém, destaca-se o fato de que Proteus mirabilis só foi isolado nesta linhagem, e em alta frequiência (55\%), resultado que mostra claramente uma maior suscetibilidade desta linhagem frente ao microrganismo. Este dado deve ser observado com atenção, uma vez que o sistema imune de animais geneticamente modificados ainda não foi bem caracterizado. As infecções que ocorrem naturalmente indicam que eles têm grande potencial para se tornarem animais modelo para estudo da bactéria em questão (FRANKLIN, 2006). Um indicativo de que a intervenção em seu material genético pode ter influenciado na maior suscetibilidade desta linhagem ao $P$. mirabilis é que esses camundongos têm sua origem no C57BL/6, no qual a bactéria não foi isolada.

Os resultados diferentes de antibiograma indicam tratar-se de estirpes de $E$. coli diferentes em cada linhagem. Tal fato pode acontecer em decorrência dos plasmídios, uma vez que cada $E$. coli possui um ou dois plasmídios conjugativos e podem transportar de dez a 15 plasmídios não conjugativos, gerando assim uma grande variedade de estirpes. Esse número pode ainda aumentar no momento da conjugação, quando ocorre a transferência de informação genética (TRABULSI et al., 2005).

A associação de resistência da E. coli a mais de três antibióticos foi encontrada com maior freqüência frente a amocixilina, cefalotina, amicacina, gentamicina, ampicilina e tobramicina $(12,99 \%)$, resultado este em desacordo com os encontrados por Pallecchi e colaboradores (2007), que observaram $34 \%$ de suas E. coli comensais humanas resistentes a ampicilina, cloranfenicol, tetraciclina, trimetoprim e sulfonamidas.

A presença de E. coli com resistência a múltiplos antimicrobianos pode inicialmente ser encarada com preocupação, uma vez que esta característica tornaria sua eliminação mais difícil, 
mas é preciso lembrar que as bactérias isoladas não são patogênicas. Como dificilmente um animal de laboratório doente seria submetido a tratamento, pensando no aspecto zoonótico desta bactéria, caso um funcionário se contaminasse por qualquer uma das estirpes estudadas e esta passasse a fazer parte de sua microbiota, ao entrar em contato com uma bactéria patogênica e ser tratado com um desses antimicrobianos, a $E$. coli não seria eliminada, ocorrendo uma menor alteração em sua microbiota, além de não liberar o LPS.

Outra importante observação a ser feita é que duas das três linhagens que apresentaram maior freqüência de E. coli, BALB/c e MDX, também foram as que apresentaram maiores índices de resistência múltipla do que os Swiss e os $\mathrm{C} 3 \mathrm{H} / \mathrm{HeJ}$; e entre os Swiss, $\mathrm{C} 3 \mathrm{H} / \mathrm{HeJ}$ e os $\mathrm{C} 3 \mathrm{H} / \mathrm{HePas}$ respectivamente. A terceira linhagem, $\mathrm{YCx} 43$ apresentou índice de resistência múltipla menor que todas as outras.

Embora a $E$. coli seja encontrada no meio ambiente e ocorra como comensal no intestino de mamíferos, a transferência horizontal de genes originou diferentes estirpes da bactéria, inclusive a transição de algumas delas de comensais para patogênicas. Já foi observado que ilhas de patogenicidade podem se disseminar horizontalmente para estirpes distintas de E. coli quando estão localizadas em plasmídios, bacteriófagos ou até no cromossomo (PICARD et al., 1999; CLARKE, 2001).

O mesmo problema foi apontado por Kruse e Sorum (1994), quando observaram a transferência de genes de resistência a múltiplos antimicrobianos entre a $E$. coli humana e a de suíno e também entre esta e a A. salomonicida subsp. salmonicida de peixe. Portanto, a resistência múltipla encontrada no presente trabalho deve ser vista com atenção, pois pode existir a possibilidade de transferência desses genes para E. coli dos manipuladores desses animais e também para outras bactérias patogênicas.

Sendo os animais utilizados neste trabalho mantidos em um biotério de padrão convencional de boa qualidade, esperava-se que eles não apresentassem, como não apresentaram, agentes patogênicos como Salmonella, assim como também fossem negativos para os fatores de virulência de E. coli estudados.

Porém, o monitoramento microbiológico ainda se faz importante uma vez que animais e humanos podem carrear bactérias patogênicas sem apresentarem sinais clínicos. Hacker et al. (1983) afirmam que mesmo em uma porcentagem baixa (12\%), a hemolisina foi encontrada em amostras fecais normais de humanos. Tal dado mostra também a importância de atentar para a 
saúde de pesquisadores e funcionários que manipulam os animais, contribuindo para a qualidade destes.

Outro dado importante foi relatado por Gyles (1979), afirmando que a toxina STb é inativa em camundongos, fato este que eleva ainda mais a importância do monitoramento microbiológico, assim como a manutenção de barreiras sanitárias eficientes no biotério, uma vez que animais infectados por uma $E$. coli com este fator de virulência não apresentariam sinais clínicos, mas representariam importante fonte de infecção para seus manipuladores.

A procura direta de determinantes de virulência é obviamente limitada aos determinantes conhecidos. Além disso, o status do hospedeiro é muito importante no desenvolvimento de uma infecção, independente da presença ou ausência de fatores de virulência (PICARD et al., 1999). Portanto, mesmo que não tenham sido isoladas bactérias patogênicas nas fezes dos camundongos, e nenhum fator de virulência da $E$. coli tenha sido detectado, todos os cuidados de biossegurança devem continuar sendo adotados no manuseio desses animais.

Caso alguma amostra se apresentasse positiva para algum fator de virulência, seria importante lembrar que a PCR detecta a presença do gene em questão na bactéria, mas não avalia sua expressão. Trata-se de um poderoso método que pode ser usado para definir a virulência de numerosas estirpes de E. coli coletadas em vários estudos, incluindo aqueles que determinam distribuições epidemiológicas.

No presente estudo não houve diferença estatisticamente significante quanto a freqüência de $Y$. enterocolítica entre as linhagens. Hancock, Schaedler e MacDonald (1986) verificaram através de infecções orais que a linhagem C57BL/6 era 1000 vezes mais resistente que BALB/c, BALB.B, Swiss, C3H/HeN DBA/2 e SWR, sendo capaz, após infecção intravenosa, de eliminar a bactéria do baço e fígado.

Esta bactéria só foi isolada nas linhagens $\mathrm{C} 3 \mathrm{H} / \mathrm{HeJ}$ e $\mathrm{YCx} 43$ e em baixa freqüência, o que levou a não diferença estatística com as outras linhagens , nas quais a $Y$. enterocolítica não foi isolada. A baixa freqüência desta bactéria no biotério pode ter mascarado diferenças de suscetibilidade como as encontradas por Hancock, Schaedler e MacDonald (1986) e pode ter sido isolada apenas nos animais $\mathrm{C} 3 \mathrm{H} / \mathrm{HeJ}$ em decorrência de sua suscetibilidade ao LPS e por algum fator ainda não identificado no animal knockout.

Segundo Urano et al. (1995), $P$. aeruginosa é freqüentemente detectada no trato intestinal de camundongos SPF ou ratos e às vezes também no ouvido médio e outros locais. A água é 
considerada um importante veículo para espalhar a bactéria e contaminar os animais. Porém, animais de laboratório positivos para $P$. aeruginosa geralmente não apresentam sinais clínicos, assim como os do presente estudo.

Microrganismos ocorrem no ar como aerossóis, consistindo de uma única célula ou um grupo delas. Elas chegam no ar através dos funcionários, encanamento do chão e pia, spray de água, ar condicionado e pó gerado por material seco. Quando pessoas são a fonte da contaminação microbiana, os principais tipos de bactérias encontradas são Staphylococcus spp, Streptococcus spp, Micrococcus spp e outros organismos encontrados no trato respiratório, cabelos e pele (SVEUM et al., 1992).

Como não há diferenças de material de limpeza, freqüência de higienização e de trocas de filtros de ar entre as salas, esperava-se que realmente também não houvesse diferenças nas bactérias lá isoladas, assim como nas luvas utilizadas pelos funcionários. Com esse resultado percebe-se também que a microbiota isolada dos animais não influenciou na presença das bactérias no ambiente, caso contrário haveria diferenças entre as salas.

Percebe-se que neste biotério as bactérias encontradas nas fezes dos animais não ocorreram com a mesma freqüência que as encontradas no ambiente (ar, mesa, porta e luvas), havendo neste, predomínio de Gram positivas, e nas fezes, Gram negativas. Uma possível explicação para este fato é apontada por Sveum et al. (1992), sendo as bactérias Gram positivas originárias de pessoas que entram nas salas dos animais, além destes próprios, uma vez que as gaiolas não possuem filtros, fato que permite que seus pêlos, pele e maravalha entrem em contato com o ar e objetos da sala.

Esta prevalência de Gram positivos no ambiente poderia ser a explicação para seu grande isolamento também nas fezes, mas esta afirmação só poderia ser confirmada através de testes como o antibiograma ou eletroforese em gel de campo pulsátil, que verificariam a possibilidade de se tratar das mesmas estirpes nos dois locais.

É importante lembrar que a exposição de pessoas e animais a esses organismos, em alta concentração no ambiente, podem resultar em reações alérgicas, doenças respiratórias e outros efeitos a saúde (STETZENBACH; BUTTNER; CRUZ, 2004). Porém, existe a necessidade de que essas medidas fossem feitas mais vezes, acompanhando flutuações que ocorrem em consequiência de um maior número de pessoas e animais na sala e realizando medidas corretivas quando a contagem aumentasse muito. 
Portanto, se diferentes linhagens são mantidas em um mesmo ambiente e são submetidas às mesmas condições, possíveis diferenças podem ser atribuídas a diferenças genéticas entre elas. Em outras palavras, a variabilidade genética pode modular diferentes respostas (DE MAIO; TORRES; REEVES, 2005).

Ainda, pesquisadores e funcionários devem encarar não só os animais, mas também o ambiente como potencial fonte de infecção, e atentar para o risco apresentarem processos infecciosos. Há necessidade então de que as medidas de biossegurança sejam respeitadas não só com relação aos animais, mas também com relação ao ambiente em que estão. 


\section{CONCLUSÕES}

- As linhagens de camundongos estudadas apresentam microbiotas fecais diferentes.

- $\quad$ As estirpes de E. coli são diferentes em cada linhagem de camundongo.

- $\quad$ As estirpes de E. coli apresentam resistência a múltiplos antibióticos.

- Com relação aos fatores de virulência pesquisados, as estirpes de E. coli isoladas não são patogênicas.

- As bactérias isoladas nas salas do biotério não foram influenciadas pela microbiota fecal dos camundongos.

- O monitoramento microbiológico de rotina dos animais, do ambiente e dos técnicos, e as normas de biossegurança são indispensáveis e devem ser sempre adotados e mantidos no biotério. 


\section{REFERÊNCIAS}

ALLEN, K. P.; RANDOLPH, M. M.; FLEEKENSTEIN, J. M. Importance of heat-labile enterotoxin in colonization of the adult mouse small intestine by human enterotoxigenic Escherichia coli strains. Infection and Immunity, v. 74, n. 2, p. 869-875, 2006.

AL-MAJALI, A. M.; ROBINSON, J. P.; ASEM, E. K.; LAMAR, C.; FREEMAN, M. J.; SAEED, A. M. Charaterization of interaction of Escherichia coli heat-stable enterotoxin (Sta) with its intestinal putative receptor in various age groups of mice, using flow cytometry and binding assays. Laboratory Animal Science, v. 49, n. 3, p. 254-258, 1999.

ANDERSEN, M. L.; D’ALMEIDA, V.; KO, G. K.; KAWAKAMI, R.; MARTINS, P. J. F.; MAGALHÃES, L. E.; TUFIK, S. Princípios éticos e práticos do uso de animais de experimentação. São Paulo: Crossete Gráfica e Editora, 2004. 167p.

ANDRADE, A. Biossegurança em biotérios. In: ANDRADE, A.; PINTO, S. C.; OLIVEIRA, R. S. Animais de laboratório: criação e experimentação. Rio de Janeiro: Editora Fiocruz, 2006. p. 381387.

ANDRADE, A. Segurança em biotérios. In: TEIXEIRA, P.; VALLE, S. Biossegurança: uma abordagem multidisciplinar. Rio de Janeiro: Editora Fiocruz, 1996. p. 225-237.

BAUER, A. W.; KIRBY, W. M. M.; SHERRIS, J. C.; TURCK, M. Antibiotic susceptibility testing by standardized single disk method. American Journal of Clinical Pathology, v. 45, p. 493-496, 1966.

BERTIN, A. Comparison of susceptibility of inbred and outbred infant mice to Escherichia coli heat-stable enterotoxin STa. Infection and Immunity, v. 60, n. 8, p. 3117-3121, 1992.

BLANCO, M.; BLANCO, J. E.; GONZALEZ, E. A.; MORA, A.; JANSE, W.; GOMES, T. A. T.; ZERBINI, F.; YANO, T.; PESTANA DE CASTRO, A. F.; BLANCO, J. Genes coding for enterotoxins and verotoxins in porcine Escherichia coli strains belonging to different $\mathrm{O}: \mathrm{K}: \mathrm{H}$ serotypes: relationship with toxic phenotypes. Journal of Clinical Microbiology, v. 35, n. 11, p. 2958-2963, 1997. 
BOOM, R.; SOL, C. J. A.; SALIMANS, M. M. M.; JANSEN, C. L.; WERTHEIM-VAN DILLEN, P. M. E.; VAN DER NOORDAA, J. Rapid and simple method for purification of nucleic acids. Journal of Clinical Microbiology, v. 28, p. 495-503, 1990.

BOOT, R.; KOOPMAN, J. P.; KUNSTYR, I. Microbiological standardization. In: VAN ZUTPHEN, L. F. M.; BAUMANS, V.; BEYNEN, A. C. Principles of laboratory animal science. A contribution to the humane use and care of animals and to the quality of experimental results. Amsterdam: Elsevier, 1993. p. 143-167.

BOPP, C.A.; BRENNER, F.W.; WELLS, J.G.; STROCKBINE, N.A. Escherichia, Shigella, and Salmonella. In: MURRAY, P. R.; BARON, E. J.; PFALLER, M. A.; TENOVER, F. C.; YOLKEN, R. H Manual of Clinical Microbiology. Washington: American Society for Microbiology Press, 1999, p. 459-482.

BRAUMANS, V. The Laboratory Mouse. In: POOLE, T. The UFAW handbook on the care and management of laboratory animal. 7. ed. Oxford: Blackwell Science Ltd, 1999. v. 1, p. 282-312.

BRITO, B. G.; VIDOTTO, M. C.; BERBEL, M. M.; TAGLIARI, K. C. Virulence factors of uropathogenic Escherichia coli - UPEC strains for pigs. Ciência Rural, v. 34, n. 2, p. 645-652, 2004.

BULFIELD, G.; SILLER, W. G.; WIGHT, P. A. L.; MOORE, K. J. X chromossome-linked muscular dystrophy (mdx) in the mouse (animal model). Proceedings of the National Academy of Sciences of the United States of America, v. 81, p. 1189-1192, 1984.

BUSCHMAN, E.; SKAMENE, E. Analysis of genetic susceptibility to infection in mice. In: ZAK, O.; SANDE, M. A. Handbook of animal models of infection. Experimental Models in antimicrobial chemotherapy. California: Academic Press, 1999. p. 75-82.

CAPRIOLI, A.; FALBO, V.; RODA, L. G.; RUGGERI, F. M.; ZONA, C. Partial purification and characterization of na Escherichia coli toxic factor that induces morfological cells alterations. Infection and Immunity, v. 39, n. 3, p. 1300-1306, 1983.

CAPRIOLI, A.; MORABITO, S.; BRUGERE, H.; OSWALD, E. Enterohaemorrhagic Escherichia coli: emerging issues on virulence and modes of transmission. Veterinary Research, v. 36, p. 289-311, 2005. 
CARDOSO, T.A.O. Considerações sobre a biossegurança em arquitetura de biotérios. 2001. Disponível em http://www.ops-oms.org/Spanish/AD/DPC/VP/boletin-aft-67-67a.pdf Acesso em 31 ago 2005.

CLARKE, S. C. Diarrhoeagenic Escherichia coli - an emerging problem? Diagnostic Microbiology and Infection Disease, v. 41, p. 93-98, 2001.

CLOUGH, G. The animal house: design, equipment and environmental control. In: POOLE, T. The UFAW handbook on the care and management of laboratory animal. 7. ed. Oxford: Blackwell Science Ltd, 1999.v. 1, p. 97-134.

CONLAN, J. W.; PERRY, M. B. Susceptibility of three strains of convencional adult mice to intestinal colonization by an isolate of Escherichia coli O157:H7. Canadian Journal of Microbiology, v. 44, p. 800-815, 1998.

DE CASTRO, A. F. P.; SERAFIM, M .B.; RANGEL, H. A.; GUERRANT, R. I. Swiss and inbred mice in the infant mouse test for the assay of Escherichia coli thermostable enterotoxin. Infection and Immunity, v. 22, n. 3, p. 972-974, 1978.

DE MAIO, A.; TORRES, M. B.; REEVES, R. H. Genetic determinats influencing the response to injury, inflamation, and sepsis. Shock, v. 23, n. 1, p. 11-17, 2005.

DONNENBERG, M. S.; WHITTAM, T. S. Pathogenesis and evolution of virulence in enteropathogenic and enterohemorrhagic Escherichia coli. The Journal of Clinical Investigation, v. 107, n. 5, p. 539-548, 2001.

DOS SANTOS. Classificação dos animais de laboratório quanto ao status genético. In: ANDRADE, A.; PINTO, S. C.; OLIVEIRA, R. S. Animais de laboratório: criação e experimentação. Rio de Janeiro: Editora Fiocruz, 2006. p. 127-138.

DUBOS, R.; SCHAEDLER, M. D.; COSTELLO, R.; HOET, P. Indigenous, normal and autochthonous flora of the gastrointestinal tract. The Journal of Experimental Medicine, v. 122, p. 67-76, 1965.

DUCHET-SUCHAUX, M. Sucklingmouse model of enterotoxigenic Escherichia coli infection. In: ZAK, O.; SANDE, M.A. Handbook of animal models of infection. Experimental Models in antimicrobial chemotherapy. California: Academic Press, 1999. p. 241-254. 
DUCHET-SUCHAUX, M.; MAITRE, C. L.; BERTIN, A. Differences in susceptibility of inbred and outbred infant mice to enterotoxigenic Escherichia coli of bovine, porcine and human origin. Journal of Medical Microbiology, v. 31, p. 185-190, 1990.

FARMER, J. J. Enterobacteriaceae: Introduction and identification. In: MURRAY, P. R.; BARON, E. J.; PFALLER, M. A.; TENOVER, F. C.; YOLKEN, R. H. Manual of Clinical Microbiology. Washington: American Society for Microbiology Press, 1999. p. 442-459.

FRANKLIN, C. L. Microbial considerations in genetically engineered mouse research. . ILAR Journal, v. 47, n. 2, p. 141-155, 2006.

FUKATA, M.; MICHELSEN, K. S.; ERI, R.; THOMAS, L. S.; HU, B.; LUKASEK, K.; NAST, C. C.; LECHAGO, J.; XU, R.; NAIKI, Y.; SOLIMAN, A.; ARDITI, M.; ABREU, M. T. Tolllike receptor-4 is required for intestinal response to epithelial injury and limiting bacterial translocation in a murine model of acute colitis. American Journal of Physiology.

Gastrointestinal and Liver Physiology, v. 288, n. 5, p. 1055-1065, 2005.

GILIOLI, R. Avaliação do perfil sanitário de colônias de camundongos e de ratos em biotérios brasileiros: ocorrências de bactérias, parasitas e vírus murinos. 2003. 138p. Tese (Doutorado) - IB/UNICAMP, Campinas.

GYLES, C. L. Limitations of the infant mouse test for Escherichia coli heat stable enterotoxin. Canadian Journal of Comparative Medicine, v. 43, p. 371-379, 1979.

HACKER, J.; HUGHES, C.; HOF, H.; GOEBEL, W. Cloned hemolysin genes fro Escherichia coli that cause urinary tract infection determine different levels of toxicity in mice. Infection and Immunity, v. 42, n. 1, p. 57-63, 1983.

HANCOCK, G. E.; SCHAEDLER, R. W.; MacDONALD, T. T. Yersinia enterocolitica infection in resistant and susceptible strains of mice. Infection and Immunity, v. 53, n. 1, p. 26-31, 1986.

HANKENSON, C. The 3R's for laboratory animal zoonoses. Contemporary Topics in Laboratory Animal Science, v. 42, n. 2, p. 66-70, 2003.

HANKENSON, F. C.; JOHNSTON, N. A.; WEIGLER, B. J.; Di GIACOMO, R. F. Zoonoses of occupational health importance in contemporary laboratory animal research. Comparative Medicine, v. 53, n. 6, p. 579-601, 2003. 
HIRSH, D. C.; ZEE,Y. C. Enterobacteriaceae: Escherichia. In: HIRSH, D. C. Microbiologia Veterinária. Rio de Janeiro: Guanabara Koogan, 2003. p. 63-68.

HOPKINS, W. J. Mouse model of ascending urinary tract infection. In: ZAK, O.; SANDE, M.A. Handbook of animal models of infection. Experimental Models in antimicrobial chemotherapy. California: Academic Press, 1999. p. 435-440.

HOPKINS, W. J.; GENDRON-FITZPATRICK, A.; BALISH, E.; UEHLING, D. T. Time course and host responses to Escherichia coli urinary tract infection in genetically distinct mouse strains. Infection and Immunity, v. 66, n. 6, p. 2798-2802, 1998.

HOPKINS, W. J.; GENDRON-FITZPATRICK; McCARTHY, D. O.; HAINE, J. E.; UEHLING, D. T. Lipopolysaccharide-responder and nonresponder $\mathrm{C} 3 \mathrm{H}$ mouse strains are equally susceptible to an induced Escherichia coli urinary tract infection. Infection and Immunity, v. 64, n. 4, p. 1369-1372, 1996.

HUDALT, S.; GUIGNOT, J.; SERVIN, A. L. Escherichia coli strains colonising the gastrointestinal tract protect germfree mice against Salmonella typhimurium infection. Gut, v. 49, p. 47-55, 2001.

ILAR NEWS. Long-term holding of laboratory rodents. v. XIX, n. 4, p. L7, 1976.

IWAHI, T.; ABE, Y.; NAKAO, M.; IMADA, A.; TSUCHIYA, K. Role of type 1 fimbriae in the pathogenesis of ascending urinary tract infection induced by Escherichia coli in mice.Infection and Immunity, v. 39, n. 3, p. 1307-1315,1983.

JACKSON LABORATORY. Jax® mice strain information [2007]. Disponível em: http: //jaxmice.jax.org/info/strain_categories.html. Acesso em: 18 jun 2007.

JOHNSON, J. R. Urinary tract infection. In: SUSSMAN, M. Escherichia coli mechanisms of virulence. New York: Cambridge University Press, 1997. p. 495-549.

JUSTICE, S. S.; HUNG, C.; THERIOT, J. A.; FLETCHER, D. A.; ANDERSON, G. G.; FOOTER, M. J.; HULTGREN, S. J. Differentiation and developmental pathways of uropathogenic Escherichia coli in urinary tract pathogenesis. PNAS, v. 101, n. 5, p. 1333-1338, 2004. 
KARPMAN, D.; CONNELL, H.; SVENSON, M.; SCHEUTZ, E.; ALM, P.; SVANBORG, C. The role of lipopolysaccharide and Shiga-like toxin in a mouse model of escherichia coli O157:H7 infection. Journal of Infectious Diseases, v. 175, p. 611-620, 1997.

KAU, A. L.; HUNSTAD, D. A.; HULTGREN, S. Interaction of uropathogenic escherichia coli with host uroepithelium. Current Opinion in Microbiology, v. 8, p. 54-59, 2005.

KREGER-VAN-RIJ, N. J. W. The yeasts: a taxonomic study. 3.ed. Amsterdam: Elsevier Science Publisher, 1984. 1082 p.

KRIEG, N. R.; HOLT, J. C. Bergey's manual of systematic bacteriology. 9.ed. Baltimore: Willians \& Wilkins, 1994. 2255 p.

KROG, H. H.; MOUTIER, R. Identification of inbred strains of mice. II. Characterization of different substrains of the C3H strain. The Jounal of Heredity, v. 69, p. 66-70, 1978.

KRUMPERMAN, P. H. Multiple antibiotic resistance indexing of Escherichia coli to identify high-risk sources of fecal contamination of foods. Applied and Environmental Microbiology, v. 46, n. 1, p. 165-170, 1983.

KRUSE, H.; SORUM, H. Transfer of multiple drug resistance plasmids between bacteria of diverse origins in natural microenvironments. Applied and Environmental Microbiology. v. 60, n. 11. p. 4015- 4021. 1994.

LANE, M. C.; LOCKATELL, V.; MONTEROSSO, G.; LAMPHIER, D.; WEINERT, J.; HEBEL, J. R.; JONHSON, D. E.; MOBLEY, H. L. T. Role of motility in the colonization of uropathogenic Escherichia coli in the urinary tract. Infection and Immunity, v. 73, n. 11, p. 7644-7656, 2005.

LAW, D.; CHART, H. Enteroaggregative Escherichia coli. Journal of Applied Microbiology. v. 84, p. 685-697, 1998.

LENNETTE, E. H.; BALOWS, A.; HANSLER JR, W. J.; SHADOMY, H. J. Manual of clinical microbiology. 4. ed. Washington: American Society for Microbiology Press, 1985. 1149 p.

MACDOWELL, E.C.; ALLEN, E.; MACDOWELL, C.G. The prenatal growth of the mouse. The Journal of General Physiology. v. 11. p. 57-70. 1927 
MAHLER, M.; NICLAS, W. Health monitoring. In: HEDRICH, H. J. The laboratory mouse. Germany: Elsevier Academic press, 2004. 600 p.

MATSUBARA, E. H. Condições higiênico -sanitárias de meias carcaças de suínos após o abate e depois do resfriamento e análise da utilização da Lista de Verificação para avaliar boas práticas no abate de suínos. 2005. 152 f. Dissertação (Mestrado em Epidemiologia Experimental e Aplicada às Zoonoses) - Faculdade de Medicina Veterinária e Zootecnia, Universidade de São Paulo, São Paulo, 2005.

MERUSSE, J.L.B.; LAPICHIK, V.B.V. Instalações e Equipamentos. In: DE LUCCA, R.R.; ALEXANDRE, S.R.; MARQUES, T.; SOUZA, N.L.; MERUSSE, J.L.B.; NEVES, S.P. Manual para técnicos em bioterismo. São Paulo: Winner Graph. 1996, p. 15-24.

MEZADRI, T. J.; TOMÀZ, V. A.; AMARAL, V. L. L. Animais de laboratório. Cuidados na iniciação experimental. Florianópolis: Editora UFSC, 2004. 155 p.

MILES, T. D.; MCLAUGHLIN, W.; BROWN, P. D. Antimicrobial resistance of Escherichia coli isolates from broiler chickens and humans. BMC Veterinary Research, v. 2, n. 7, p. 1-9, 2006.

MOMOSE, Y.; HIRAYAMA, K.; ITOH, K. Effect of organic acids on inhibition of Escherichia coli $\mathrm{O} 157: \mathrm{H} 7$ colonization in gnotobiotic mice associated with infant intestinal microbiota.

Antonie van Leeuwenhoek, 2007.

MURRAY, P. R.; BARON, E. J.; PFALLER, M. A.; TENOVER, F. C.; YOLKEN, R. H. Manual of clinical microbiology. 7. ed. Washington: American Society for Microbiology, 1999. 1773 p.

NAGANO, K.; TAGUCHI, K.; HARA, T.; YOKOYAMA, S.; KAWADA, K.; MORI, H.

Adesion and colonization of enterohemorrhagic Escherichia coli O157:H7 in cecum of mice.

Microbiology and Immunology, v. 47, n. 2, p.125-132, 2003.

NATARO, J. P.; KAPER, J. B. Diarrheagenic Escherichia coli. Clinical Microbiology Reviews, v. 11, n. 1, p. 142-201,1998.

NATIONAL COMMITTEE FOR CLINICAL LABORATORIES STANDARDS (NCCLS). Performance standards for antimicrobial disk susceptibility testing. 4. ed. Pensylvania:, 2001. 
NAVEEN, R.; MATHAI, E. Some virulence characteristics of uropathogenic Escherichia coli in different patient groups. The Indian Journal of Medical Research, v. 122, p. 143-147, 2005.

O'BRIEN, A. D.; LAVECK, G. D.; GRIFFIN, D. E.; THOMPSON, M. R. Characterization of Shigella dysenteriae 1 (Shiga) toxin purified by anti-Shiga toxin affinity chromatography.

Infection and Immunity, v.30, n. 1, p.170-179, 1980

OLORIS, S. C. S. Avaliação do papel da conexina 43 no desenvolvimento do granuloma, experimentalmente induzido em camundongos. 2005. 118,f. Tese (Doutorado em Patologia Experimental e Comparada) - Faculdade de Medicina Veterinária e Zootecnia, Universidade de São Paulo, São Paulo, 2005.

OLSVIK, O.; STROCKBINE, N.A. PCR detection of heat-stable, heat-labile, and shiga-like toxin genes in Escherichia coli. In: PERSING, D.H.; SMITH, T.F.; TENOVER, F.C.; WHITE, T.J. Diagnostic molecular microbiology: principles and applications. Washington: American Society for Microbiology. p. 271-276, 1993.

ORSKOV, F. Escherichia coli. In: KRIEG, N. R.; HOLT, J. G. Bergey's manual of systematic bacteriology. 9. ed. Baltmore: Williams \& Wilkins, 1994. p. 420-423.

PALERMO-NETO, J.; ALMEIDA, R. T. Antimicrobianos como aditivos em animais de produção. In: SPINOSA, H. S.; GÓRNIAK, S. L.; BERNARDI, M. M. Farmacologia aplicada à medicina veterinária. São Paulo: Ganabara Koogan, 2002. p. 558-573.

PALLECCHI, L.; LUCCHETTI, C.; BARTOLONI, A. ; BARTALESI, F.; MANTELLA, A.; GAMBOA, H.; CARATTOLI, A.; PARADISI, F.; ROSSOLINI, G. M. Population structure and resistance genes in antibiotic-resistant bacteria from a remote community with minimal antibiotic exposure. Antimicrobial Agents and Chemotherapy, v. 51, n. 4, p. 1179-1184, 2007.

PEREIRA, A. M. Principais doenças dos camundongos, ratos e hamsters. In: ANDRADE, A.; PINTO, S. C.; OLIVEIRA, R. S. Animais de laboratório: criação e experimentação. Rio de Janeiro: Editora Fiocruz, 2006. p. 127-138.

PICARD, B.; GARCIA, J. S.; GOURIOU, S.; DURIEZ, P.; BRAHIMI, N.; BINGEN, E.; ELION, J.; DENAMUR, E. The link between phylogeny and virulence in Escherichia coli extraintestinal infection. Infection and Immunity, v. 67, n. 2, p. 546-553, 1999. 
POLETTO, K. Q.; REIS, C. Suscetibilidade antimicrobiana de uropatógenos em pacientes ambulatoriais na Cidade de Goiânia, GO. Revista da Sociedade Brasileira de Medicina Tropical, v. 38, n. 5, p. 416-420, 2005.

POLLARD, D. R.; JOHNSON, W. M.; LIOR, H.; TYLER, S. D.; ROZES, K. R. Rapid and specific detection of verotoxin genes in Escherichia coli by the polymerase chain reaction. Jounal of Clinical Microbiology, v. 28, n. 3, p. 540-545, 1990.

QUADRI, F.; SVENNERHOLM, A. M.; FARUQUE, A. S. G.; SACK, R. B. Enterotoxigenic Escherichia coli in developing countries: epidemiology, microbiology, clinical features, treatment, and prevention. Clinical Microbiology Reviews, v. 18, n. 3, p. 465-483, 2005.

QUINN, P. J.; MARKEY, B. K.; CARTER, M. E.; DONNELLY, W. J.; LEONARD, F. C. Microbiologia veterinária e doenças infecciosas. Porto Alegre: Artmed, 2005. 512 p.

RAZZAQ, S. Hemolytic uremic syndrome: na emerging health risk. American Family Physician, v. 74, n. 6, p. 991-996, 2006.

REAUME, A. G.; SOUSA, P. A.; KULKARNI, S.; LANGILLE, B. L.; ZHU, D.; DAVIES, T. C.; JUNEJA, S. C.; KIDDER, G. M.; ROSSANT, J. Cardiac malformation in neonatal mice lacking connexin43. Science, v. 267, p. 1831-1834, 1995.

REHBINDER, C.; BANEAUX, P.; FORBES, D.; HERCK, H. V.; NICLAS, W.; RUGAYA, Z.; WINKLER, G. FELASA Recomendations for the Health Monitoring of Mouse, Rat, Hamster, Gerbil, Guineapig and Rabbit Experimental Units. Laboratory Animals, v. 30, p.193-208, 1996.

RILEY, L. W.; REMIS, R. S.; HELGERSON, S. D.; McGEE, H. B.; WELLS, J. G.; DAVIS, B. R.; HEBERT, R. J.; OLCOTT, E. S.; JOHNSON, L. M.; HARGRETT, N. T.; BLAKE, P. A.; COHEN, M. L. Hemorrhagic colitis associated with a rare Escherichia coli serotype. New England Journal of Medicine, v. 308, p. 681-685, 1983.

ROE, A. J.; GALLY, D. L. Enterophatogenic and enterohaemorrhagic Escherichia coli and diarrhoea. Current Opinion in Infectious Diseases, v. 13, n. 5, p. 511-517, 2000.

SALZMAN, N. H.; DE JONG, H.; PATERSON, Y.; HARMSEN, H. J. M.; WELLING, G. W.; BOS, N. A. Analysis of 16S libraries of mouse gastrointestinal microbiota reveals a large new group of mouse intestinal bacteria. Microbiology, v. 148, p. 3651-3660, 2002. 
SARMENTO, E. O. Biossegurança e experimentação animal. Revista CFMV, n. 36. p. 9-15, 2005.

SAVARIANO, S. J.; FASANO, A.; ROBERTSON, D. C.; LEVINE, M. M. Enteroaggregative Escherichia coli elaborate a heat-stable enterotoxin demonstrable in an in vitro rabbit intestinal model. The Journal of Clinical Investigation, v. 87, p. 1450-1455, 1991.

SAWANT, A. A.; HEGDE, N. V.; STRALEY, B. A.; DONALDSON, S. C.; LOVE, B. C.; KNABEL, S. J.; JAYARAO, B. M. Antimicrobial-resistant enteric bacteriafrom dairy cattle. Applied and environmental microbiology, v. 73, n. 1, p. 156-63, 2007.

SCHAEDLER, R. W.; DUBOS, R.; COSTELLO, R. The development of the bacterial flora in the gastrointestial tract of mice. The Journal of Experimental Medicine, v. 122, p. 59-66, 1965.

SCHILLING, J. D.; LORENZ, R. G.; HULTGREN, S. J. Effect of Trimethoprimsulfamethoxazole on recurrent bacteriuria and bacterial persistence in mice infected with uropathogenic Escherichia coli. Infection and Immunity, v. 70, n. 12, p. 7042-7049, 2002.

SCHULTSZ, C.; POOL, G. J.; VAN KETEL, R.; WEVER, D.; SPEELMAN, P.; DANKERT, J. Detection of enterotoxigenic Escherichia coli in stool samples by using non-radioactively labeled oligonucleotide DNA probes and PCR. Jounal of Clinical Microbiology, v. 32, n. 10, p. 2393 2397, 1994.

SERVIN, A. L. Pathogenesis of Afa/Dr diffusely adhering Escherichia coli. Clinical Microbiology Reviews, v. 18, n. 2, p. 264-292, 2005.

SMITH, M. W. Safety hygiene. In: POOLE, T. The UFAW handbook on the care and management of laboratory animal. 7. ed. New York: Blackwell Science Ltd, 1999. v. 1, p. 141171.

STAATS, J. Standardized nomenclature for inbred strains of mice: eighth listing. Cancer Research, v. 45, p. 945-976, 1985.

STATISTICAL ANALISYS SYSTEM. SAS user's guide: statistics. Versão 8.02. Cary: SAS, 2001. 
STETZENBACH, L. D.; BUTTNER, M. P.; CRUZ, P. Detection and enumeration of airborne biocontaminants. Current opinion in Biotechnology, v. 15, p. 170-174, 2004.

STRONG, L. C. The establishment of the C3H inbred strain of mice for the study of spontaneous carcinoma of the mammary gland. Genetics, v. 20, p. 586-591, 1935.

SVEUM, W.H.; MOBERG, L.J.; RUDE, R.A.; FRANK, J.I. Microbiological monitoring of the food processing environment. In: VANDERZANT, C.; SPITTSTESSER, D.F. Compendium of Methods For the Microbiological Examination of Foods. 3.ed. Washington: American Public Health Association, 1992. p. 51-74.

TACONIC. Traditional / spontaneous mutant mouse and rat models. [2007] Disponível em http://www.taconic.com/wmspage.cfm?parm1=579. Acesso em 02 jul 2007.

TEIXEIRA, P.; VALLE, S. Biossegurança: uma abordagem multidisciplinar. Rio de Janeiro: Editora Fiocruz, 1996. 362 p.

TORTORA, G. J.; FUNKE, B. R.; CASE, C. L. Doenças microbianas do sistema digestivo. In: Microbiologia. Porto Alegre: Artes Médicas Sul LTDA, 2000. p. 658-689.

TRABULSI, L. R.; ALTERTHU, F.; MARTINEZ, M. B.; CAMPOS, L. C.; GOMPERTZ, O. F.; RÁCZ, M. L. Microbiologia. São Paulo: Editora Atheneu, 2005. 718 p.

TRABULSI, L. R.; TOLEDO, M. R. F. Resistência bacteriana a drogas. In: TRABULSI, L. R.; ALTERTHUM, F.; GOMPERTZ, O. F.; CANDEIAS, J. A. N. Microbiologia. São Paulo: Atheneu, 1999. p.105-109.

TURNER, S. M.; SCOTT-TUCKER, A.; COOPER, L. M.; HENDERSON, I. R. Weapons of mass destruction: virulence factor of the global killer enterotoxigenic Escherichia coli. FEMS Microbiology Letters, v. 263, p. 10-20, 2006.

URANO, T.; NOGUCHI, K.; JIANG, G.; TSUKUMI, K. Survey of Pseudomonas aeruginosa contamination in human beings and laboratory animals. Experimental Animals / Japanese Association for Laboratory Animal Science, v. 44, n. 3, p. 233-239, 1995. 
VALLANCE, B. A.; DENG, W.; JACOBSON, K.; FINLAY, B. B. Host susceptility to the attaching and effacing bacterial pathogen Citrobacter rodetium. Infection and Immunity, v. 71, n. 6, p. 3443-3453, 2003.

WOODWARD, M. J.; CARROL, P. J.; WRAY, C. Detection of entero and verocyto-toxin genes in Escherichia coli from diarrhea disease in animals using polymerase chain reaction. Veterinary Microbiology, v. 31, p. 251-261, 1992.

YAMAMOTO, S.; KURAZONO, H.; TAKEDA, Y.; YOSHIDA, O. Detection of urovirulence factors in Escherichia coli by multiplex polymerase chain reaction. FEMS Immunology and Medical Microbiology, v. 12, p. 85-90, 1995.

YATSUYANAGI, J.; SAITO, S.; SATO, H.; MIYAJIMA, Y.; AMANO, K.; ENOMOTO, K. Characterization of enteropathogenic and enteroaggegative Escherichia coli isolated from diarrheal outbreaks. Journal of Clinical Microbiology, v. 40, n. 1, p. 294-297, 2002.

YURI, K.; NAKATA, K.; KATAE, H.; YAMAMOTO, S.; HASEGAWA, A. Distribution of uropathogenic virulence factors among Escherichia coli strains isolated from dogs and cats. The Journal of Veterinary Medical Science / The Japanese Society of Veterinary Science, v. 60, n. 3, p. 287-290, 1998. 